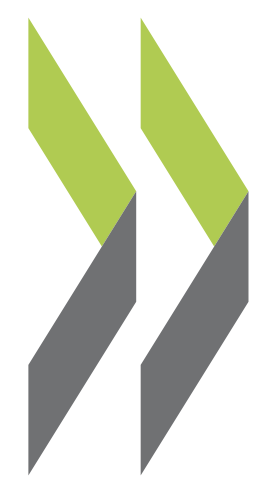

OECD Science, Technology and Industry Working Papers $2011 / 02$

\title{
Opening Japan: Comparisons with Other G20 Countries and Lessons Learned from International Experience
}

\section{Andrea Beltramello,} Koen De Backer, Victor Mercader, Laurent Moussiegt 
Organisation de Coopération et de Développement Économiques

Organisation for Economic Co-operation and Development

22-Aug-2011

DIRECTORATE FOR SCIENCE, TECHNOLOGY AND INDUSTRY

English - Or. English

OPENING JAPAN - COMPARISONS WITH OTHER G20 COUNTRIES AND LESSONS LEARNED FROM INTERNATIONAL EXPERIENCE

STI WORKING PAPER 2011/2

By Andrea Beltramello, Koen De Backer, Victor Mercader and Laurent Moussiegt (OECD) 


\section{STI Working Paper Series}

The Working Paper series of the OECD Directorate for Science, Technology and Industry is designed to make available to a wider readership selected studies prepared by staff in the Directorate or by outside consultants working on OECD projects. The papers included in the series cover a broad range of issues, of both a technical and policy-analytical nature, in the areas of work of the DSTI. The Working Papers are generally available only in their original language - English or French - with a summary in the other.

Comments on the papers are invited, and should be sent to the Directorate for Science, Technology and Industry, OECD, 2 rue André-Pascal, 75775 Paris Cedex 16, France.

The opinions expressed in these papers are the sole responsibility of the author(s) and do not necessarily reflect those of the OECD or of the governments of its member countries.

www.oecd.org/sti/working-papers

OECD/OCDE, 2011

Applications for permission to reproduce or translate all or part of this material should be made to: OECD Publications, 2 rue André-Pascal, 75775 Paris, Cedex 16, France; e-mail: rights@oecd.org 


\section{ABSTRACT \\ Andrea Beltramello, Koen De Backer, Victor Mercader and Laurent Moussiegt}

Openness has been shown to be an important driver of economic growth. Because of the broad character of the current globalisation process, openness has many dimensions: trade (in both goods and services), foreign direct investment (FDI), circulation of people (including the highly skilled), and internationalisation of R\&D, technology and knowledge. Economies not only benefit from inward flows of goods, services, people, capital and knowledge, but also from outward flows of those factors of production. But economic openness does not necessarily yield automatic benefits, and governments may need to complement policies to open the economy with policies that help individuals and firms adjust to liberalisation and ensure that aggregate benefits for the domestic economy are optimised. This working paper aims to assess the openness of the Japanese economy and to show how policies promoting openness are conducive to long-term growth. First, the paper benchmarks Japan in terms of openness in an international perspective relative to other G20 countries. Second, it reviews the theoretical and empirical literature on the link between openness and economic growth. Third, it illustrates the role that governments can play in stimulating openness and growth by presenting several case studies of countries that have implemented specific policies to promote openness in particular domains.

\section{RÉSUMÉ}

\section{Andrea Beltramello, Koen De Backer, Victor Mercader et Laurent Moussiegt}

L'ouverture est un moteur important de la croissance économique. En raison du caractère global du processus actuel de mondialisation, l'ouverture a plusieurs dimensions : le commerce international (tant des biens que des services), l'investissement direct étranger (IDE), la circulation des personnes (y compris des travailleurs hautement qualifiés), et l'internationalisation de la R-D, de la technologie et des connaissances. Les pays bénéficient non seulement de flux entrants de biens, services, personnes, capitaux et connaissances, mais aussi de flux sortants de ces facteurs de production. Mais l'ouverture économique ne génère pas nécessairement des avantages automatiques, et il se peut que les gouvernements doivent compléter les politiques visant à ouvrir l'économie avec des mesures qui aident les individus et les entreprises à s'adapter à la libéralisation et s'assurer que les avantages globaux pour l'économie nationale sont optimisés. Ce document de travail a pour objectif d'évaluer l'ouverture de l'économie japonaise et de montrer comment les politiques favorisant l'ouverture sont propices à la croissance à long terme. Premièrement, l'ouverture de l'économie japonaise est comparée à celle des autres pays du G20. Deuxièmement, le document examine la littérature théorique et empirique à propos du lien entre ouverture et croissance économique. Troisièmement, il illustre le rôle que les gouvernements peuvent jouer pour stimuler l'ouverture et la croissance économique en présentant plusieurs études de cas de pays qui ont mis en œuvre des politiques spécifiques pour promouvoir l'ouverture dans des domaines particuliers. 
DSTI/DOC(2011)2 


\section{TABLE OF CONTENTS}

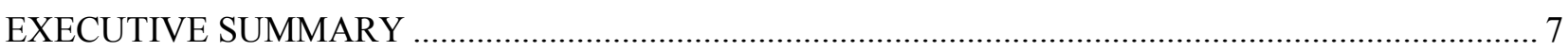

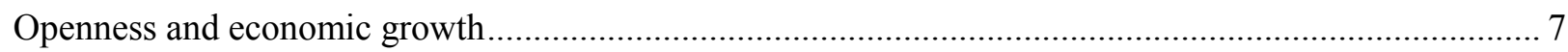

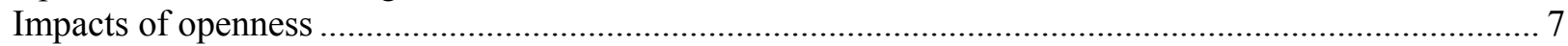

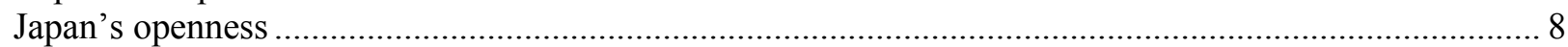

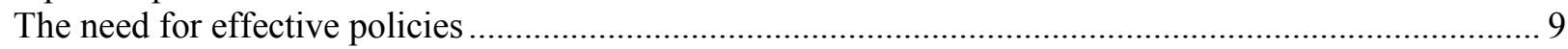

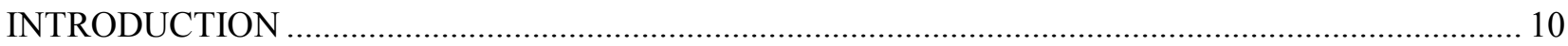

CHAPTER 1. INTERNATIONAL BENCHMARKING OF OPENNESS …......................................... 11

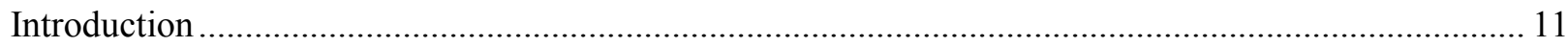

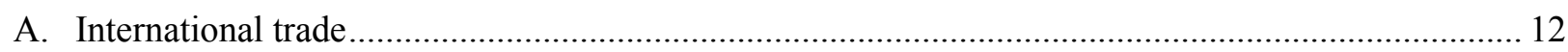

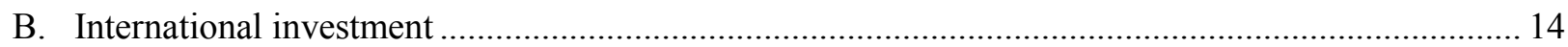

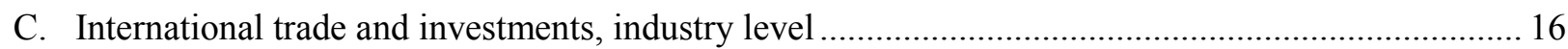

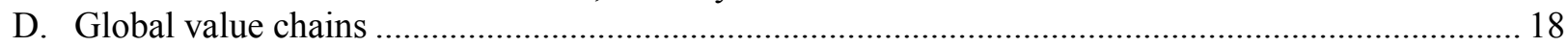

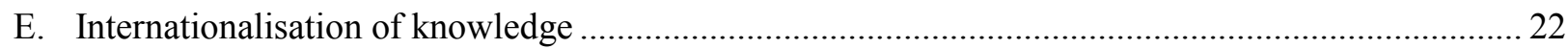

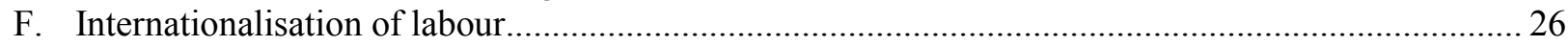

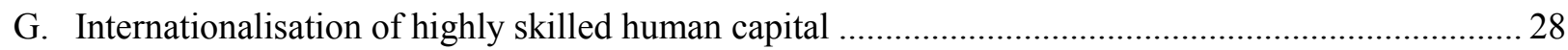

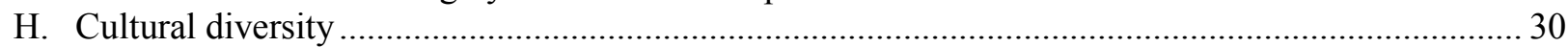

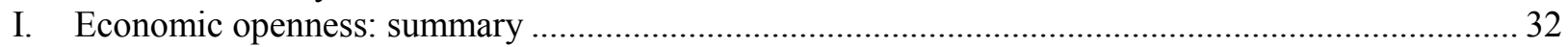

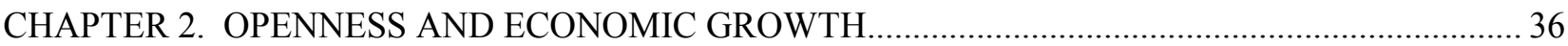

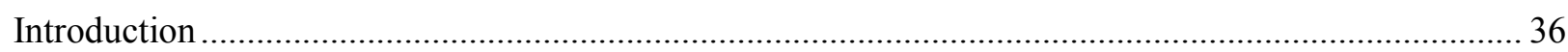

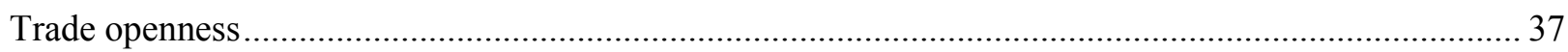

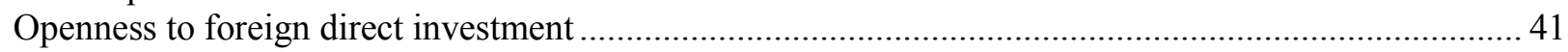

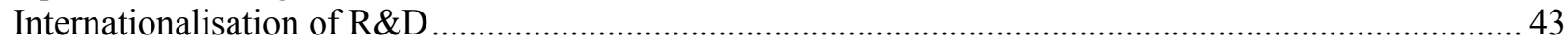

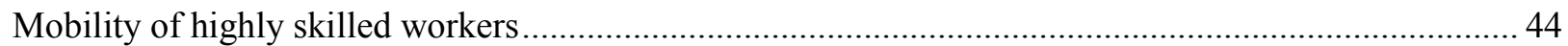

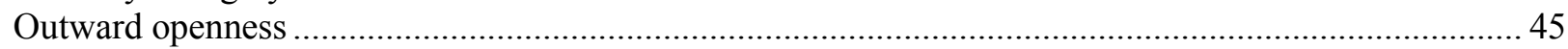

Conclusion: Openness can generate sizeable benefits for the local economy......................................... 46

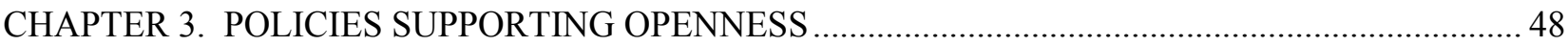

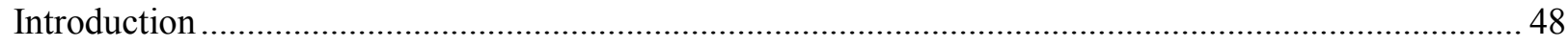

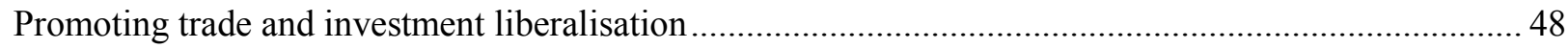

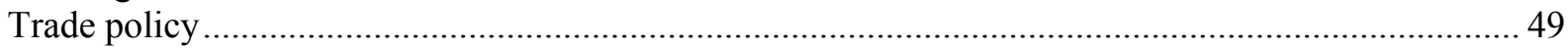

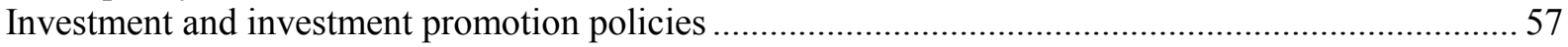

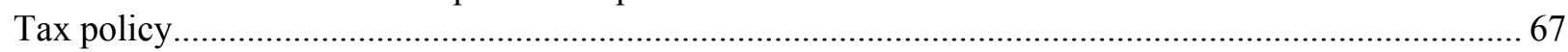

Policies to foster the internationalisation and openness of R\&D and innovation ................................. 70

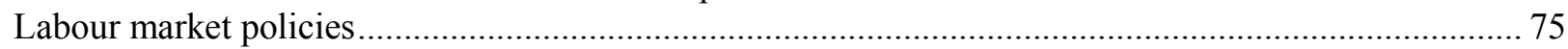

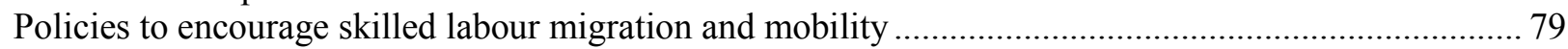

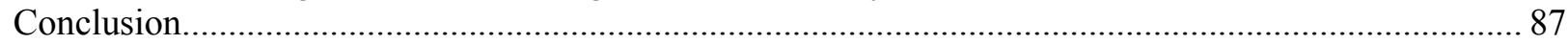

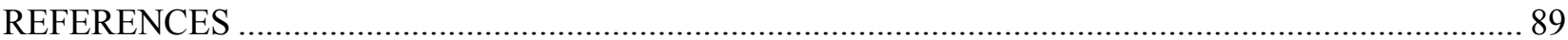


ANNEX 1: ECONOMIC GROWTH THEORY AND OPENNESS

.99

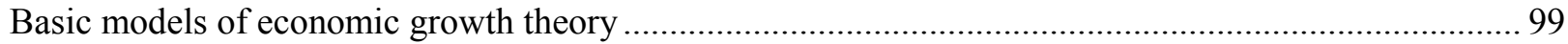

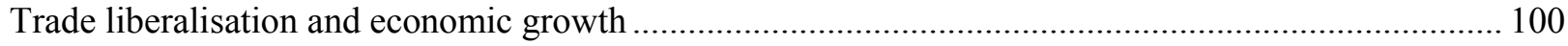

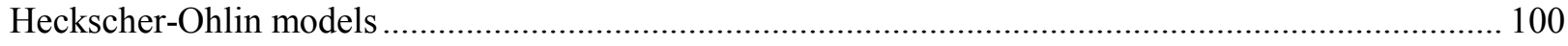

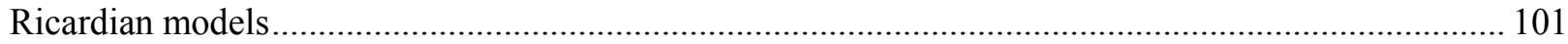

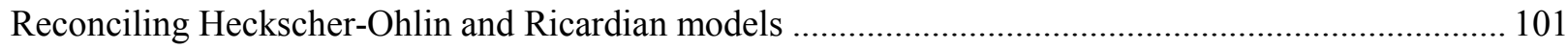

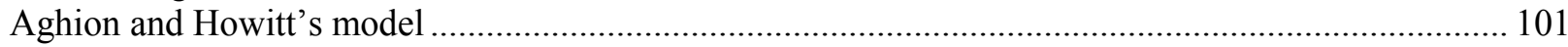




\section{EXECUTIVE SUMMARY}

\section{Openness and economic growth}

Stronger economic growth is a top priority for most countries, in particular in the aftermath of the economic crisis. Economic growth leads to higher living standards and directly determines the level of income. Economic growth is due to a range of factors, including capital accumulation, labour productivity growth, and technology adoption, among others. Openness is another key determinant and has been shown to be an important driver of economic growth; more open countries typically grow faster than less open countries, as openness exposes countries to ideas, capital, labour, technology, etc. from abroad.

Because of the broad character of the current globalisation process, openness has many dimensions. Apart from traditional channels such as trade (in both goods and services) and foreign direct investment (FDI), globalisation today also encompasses the circulation of people (including the highly skilled), R\&D, technology and knowledge. In addition, economies not only benefit from flows entering the country but also from outward flows, e.g. due to learning from exporting and foreign investment. Government policy should therefore not only aim to open the domestic economy to economic actors from abroad, but also promote and stimulate domestic firms to engage in activities abroad.

\section{Impacts of openness}

Openness to international trade helps countries specialise in the activities in which they possess a comparative advantage, increases competition on product and labour markets and helps realise economies of scale. Industries with relatively large reductions in trade costs tend to experience larger increases in productivity, fuelled by intra-industry reallocations and the reduction of inefficiencies at the firm level. Due to the increasing importance of global value chains and the growing volumes of intermediate inputs that are traded internationally, countries may benefit even more from openness since imports of intermediate goods embody critical transfers of technology.

Openness to international investment contributes to the expansion of productive capacity, job creation, human capital enhancement, innovation and technology diffusion, and enterprise development and also supports growth in overall incomes. Local capabilities are typically enhanced by FDI, as this provides access to efficient organisational practices, machinery, and technologies. Furthermore, because of spill-over effects, (unintended) benefits might result from MNEs for the local economy. When these spillover effects are absorbed by local suppliers and customers, the local workforce, and local firms, FDI may also contribute to productivity growth for the host economy.

International investment specifically in R\&D may result in a more efficient innovation process, a stronger ability to learn about R\&D conducted abroad, a faster road to commercialisation, and a positive impact on the firm's own innovation capacity. In addition, host countries might benefit from inward R\&D as this will directly impact the competitiveness and productivity of foreign affiliates.

Openness to talented individuals from abroad may prove to be necessary to achieve and sustain high rates of productivity and output growth in the OECD knowledge economies; the more so since many OECD countries are expected to face severe skill shortages in the coming years. Conventional wisdom 
holds that the transfer of highly educated people from one country to another (commonly referred to as "brain drain") will lead to a loss of productive and innovative capacity of the sending country. But the temporary and circulation migration between home and abroad may also be beneficial to the sending countries. Individuals may transfer the knowledge they acquire to their home country and maintain networks abroad; they often return to the home country after a period abroad and will likewise transfer knowledge ("brain circulation").

While it can be concluded that economies benefit on the whole from increased openness, some adjustment costs are often incurred, especially in sectors that benefit the most from protection. Likewise, some negative impacts of openness might arise for specific occupations and skills categories in the labour market. This does not mean that such groups should be shielded from greater openness, but that policies to foster the opening of economies need to be complemented with other policies that enable those affected to find new opportunities.

The internationalisation of production and the emergence of global value chains (GVCs) have raised fears about the offshoring of activities and jobs to foreign countries, especially those that enjoy lower production costs. However, most of the literature that has explored this issue concludes that the overall impact of internationalisation of production on the domestic labour market is relatively small and often has a temporary character. Furthermore, offshoring of activities and investment abroad benefits the home country in terms of productivity, innovation and competitiveness. Indeed, firms that offshore (labourintensive) jobs to low-cost countries may end up saving domestic jobs since offshoring tends to strengthen international competitiveness.

\section{Japan's openness}

Overall, the Japanese economy seems to be relatively closed especially when compared to the United Kingdom and Germany and to a lesser extent also compared with the United States and Korea. A benchmark exercise across 27 indicators covering international trade, international investment, global value chains, internationalisation of knowledge, internationalisation of labour, internationalisation of highly skilled human capital and cultural diversity indicate that Japan is relatively closed across most policy domains.

Japan scores better on indicators of trade and global value chains, which is linked to the process of vertical specialisation that has taken place within Asia. Exports of Japan are to a large extent made up of imported intermediates, while in turn Japan produces and exports high value intermediate inputs (e.g. parts and components) for their (low cost) assembly in other Asian economies.

Notwithstanding the important role of affiliates of Japanese multinationals abroad, Japan scores relatively low on international investments, including through mergers and acquisitions. But Japan is also relatively closed on indicators of the internationalisation of knowledge, notably compared with the United Kingdom and Germany. International collaboration in science, $R \& D$, patents and innovation is significantly smaller than in other G20 countries.

The differences between Japan and other countries are particularly marked on indicators of the internationalisation of the labour market, including the mobility of highly skilled human capital. Both in terms of immigration and emigration, Japan shows very low levels of openness, and the difference with other countries is again particularly marked as regards inward migration. The direct result of this is a lower degree of diversity in the population and the labour force in Japan. 


\section{The need for effective policies}

Economic openness does not necessarily yield automatic benefits, and well designed government policies are needed to ensure that the national economy draws benefits from greater openness. There is a clear need for complementary policies along different lines to make sure that firms adjust to greater openness of the domestic economy and to ensure that aggregate benefits for the host economy are optimised.

Governments therefore need to complement policies to open the economy with policies that help the economy adjust to liberalisation and ensure that the economic benefits stemming from openness are maximised. Japan has actively promoted the free movement of goods and capital, but more could be done in particular to attract investment, innovation activities and highly-skilled individuals that can generate positive spillovers for the national economy.

Barriers to trade and investment are still present in the Japanese economy and foreign operators still face significant non-tariff measures when exporting to Japan. In addition, Japan is among the countries with the highest level of restrictions to FDI. The number of greenfield projects in innovation-related activities in Japan has been relatively low in recent years. And while Japan has recently introduced a number of policies to promote the internationalisation of knowledge, the internationalisation of science and industry is weaker in Japan than in many other OECD countries.

Japan is characterised by a low degree of openness on its labour market, including for the highly skilled. Japan has recently introduced special migration schemes for highly skilled workers and has also introduced programmes to encourage return migration and therefore stimulate brain circulation. The significant gap in this area will require a continued policy effort for some time to come.

A range of case studies included in the paper illustrate how some countries have tackled their problems of openness by designing and implementing specific policies. While these case studies can serve as illustrations of good practice and offer some detailed policy insights, the same policies cannot necessarily be duplicated in Japan. The success and validity of policies is dependent on the specific needs and challenges of individual countries. Likewise, there is no optimal degree of openness for countries as this will depend on the situation of countries in terms of industrial structure, location, history, etc. 


\section{INTRODUCTION}

This report aims to assess the openness of the Japanese economy and to show how policies promoting economic openness are conducive to long-term economic growth. This study analyses economic openness in the context of regional economic integration and increasing globalisation of production; policies that promote economic openness are important drivers of a country's integration into global value chains.

The report applies a broad approach to analyse the economic openness along different dimensions, in order to capture the different characteristics of today's globalisation. A first chapter benchmarks Japan in terms of openness in an international perspective relative to other G-20 countries. Reflecting the multiple dimensions of openness (trade, FDI, labour, highly skilled human capital, innovation and R\&D, etc.), this exercise combines different indicators including both inbound and outbound flows. Existing OECD indicators are included as well as new indicators in order to address the specificities of this study.

In addition to the performance on individual indicators, an overall picture is given presenting the openness of Japan relative to countries like the United States, United Kingdom, Germany and Korea. Instead of using one single synthetic indicator, Japan is compared along different dimensions, enabling policy makers to identify with one glance in which domains the country is lagging.

A second chapter reviews the theoretical and empirical literature on the link between openness and economic growth. Given that this literature is vast and diverse, the most important conclusions across the different dimensions of economic openness are discussed in direct relation to the Japanese economy. While this chapter is somewhat more technical in nature, it focuses on potential conclusions emerging from the literature that are directly relevant for policy. More technical details are included in the annex.

A third chapter focuses on government policies for openness and highlights the role that government can play in stimulating economic openness and growth. This chapter also includes a (limited) comparison of Japan with other countries in terms of specific policies along the different dimensions of openness. This last section also includes several case studies of countries that have implemented specific policies to promote openness in particular domains. Objectives, characteristics and outcomes (if available) are discussed for these case studies.

The study was prepared by the OECD Directorate for Science, Technology and Industry. Andrea Beltramello, Victor Mercader, Laurent Moussiegt, Koen De Backer and Dirk Pilat of the Structural Policy Division contributed to this report. 


\section{CHAPTER 1. INTERNATIONAL BENCHMARKING OF OPENNESS}

\section{Introduction}

This section aims to benchmark Japan in terms of openness in an international perspective. Because of the multiple dimensions of openness (trade, FDI, labour, highly skilled human capital, innovation and R\&D, etc.), this exercise combines different indicators including both inbound and outbound flows.

The list of indicators in this benchmark exercise is not exhaustive; instead the most important indicators have been selected to give an overall picture of the economic openness of Japan. In total, 27 indicators have been collected, covering international trade (3), international investment (3), global value chains (6), internationalisation of knowledge (6), internationalisation of labour (3), internationalisation of highly skilled human capital (3) and cultural diversity (3). In contrast to the other categories, the indicators on cultural diversity are exclusively based on survey data.

Japan has been benchmarked relative to the G-20 countries (Argentina, Australia, Brazil, Canada, China, France, Germany, India, Indonesia, Italy, Mexico, Russia, Saudi Arabia, South Africa, Republic of Korea, Turkey, United Kingdom, United States, the European Union). Not all indicators are however presented for all countries due to limited data availability. When available, the OECD average has been included. The comparison with G-20 countries intends to enhance the relevance of the benchmarking as differences in economic openness will be less influenced by size differences between small and large countries.

In the concluding session an overall picture is presented of the (economic) openness of Japan by combining the different indicators into a single graph. Instead of calculating one synthetic indicator, all the indicators are combined and compared with the 'best' scoring country. This methodology enables policy makers to identify with one glance in which domains the country is lagging. The discussion in the paper focuses particularly on the comparison of Japan with the United States, United Kingdom, Germany and Korea.

Throughout the comparison, it is important to note that there is not necessarily an optimal ranking for a country on one indicator; the ranking of countries typically depends on their industrial structure, geographical location, history, etc. The following discussion should therefore not be interpreted as a normative ranking of countries, but rather as a benchmarking exercise intended to analyse economic openness along different dimensions. 


\section{A. INTERNATIONAL TRADE}

Trade openness, measured as the sum of exports and imports as a percentage of GDP, is a key indicator of countries' (trade) integration in the world economy. Over the past decade, a clear trend towards increased openness can be observed in most countries including Japan. Overall, the trade openness of large countries like Japan and the United States is significantly lower than that of smaller G20 economies (Figure A.1). Because of their limited size, smaller countries tend to specialise in a limited number of sectors and need to import/export more goods and services; hence they are generally more integrated in the world economy in relation to their GDP.

A similar observation emerges for the import penetration of countries (Figure A.2). For both goods and services, Japan shows a relatively low import penetration rate especially when compared with the OECD average. Just like the United States, Japan depends less on external markets to satisfy its domestic demand. Imports into Japan originate especially from China, the United States, Australia and Korea. The high import penetration of China is typically explained by strong domestic growth and the position of China in global value chains (see below).

Japan is one of the largest exporting countries together with the United States, Germany, the United Kingdom and more recently China (Figure A.3). The three most important destination markets for Japanese exports are China, the United States and Korea. For both exports and imports, other Asian countries play an important role for Japan. The development of global value chains has resulted in a growing vertical specialisation in Asia, with Japan increasingly exporting (high value) parts and components and importing more final goods.

\section{The rate of import penetration}

The rate of import penetration (MPij) for a country $\mathrm{i}$ and a product $\mathrm{j}$ corresponds to the share of domestic demand (Dij) in country i for product $\mathrm{j}$, which is met by imports Mij.

MPij = $100 \mathrm{Mij} / \mathrm{Dij}$. If $\mathrm{P}, \mathrm{X}$ and $\mathrm{M}$ stand respectively for a country's output, export and imports, its domestic demand, $D$ will be equal to $D=P-X+M$ and then the import penetration in country $i$ for product $j$ will be

$M P i j=100 \mathrm{Mij} /(\mathrm{Pij}-\mathrm{Xij}+\mathrm{Mij})$. 


\section{A. INTERNATIONAL TRADE}

Figure A.1. Sum of exports and imports, goods and services As a percentage of GDP, at current prices

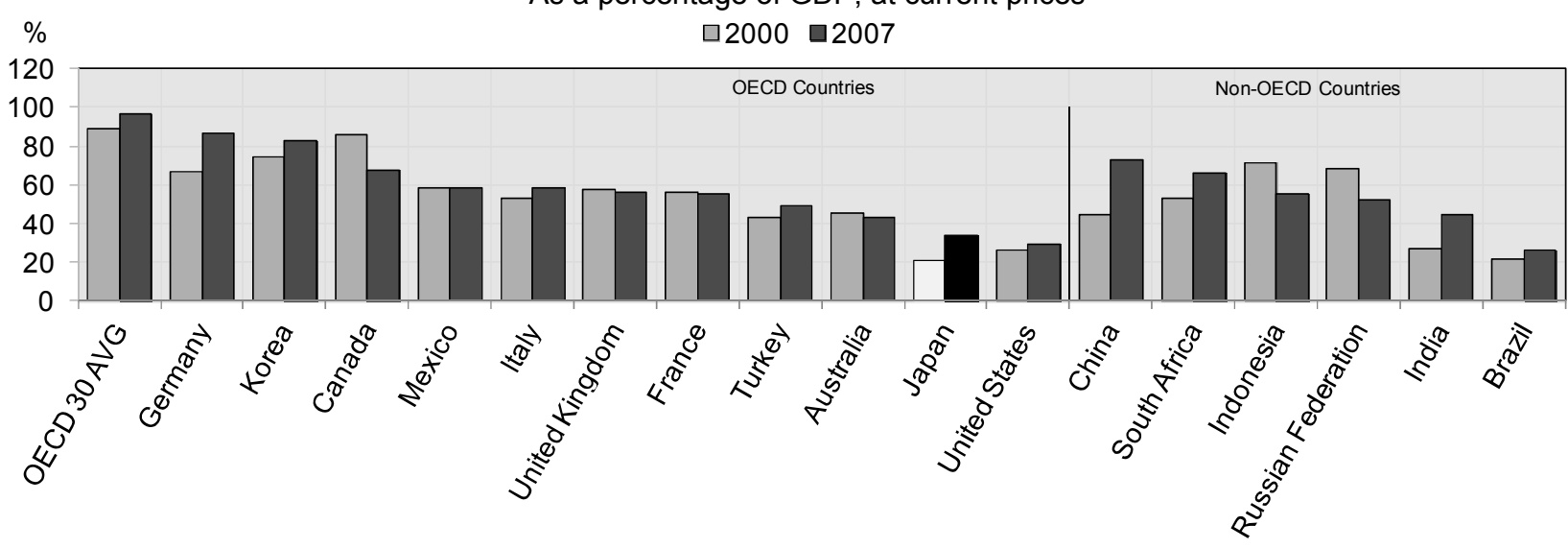

Figure A.2. Import penetration for goods and services, 2000 and 2007 As a percentage, at current prices

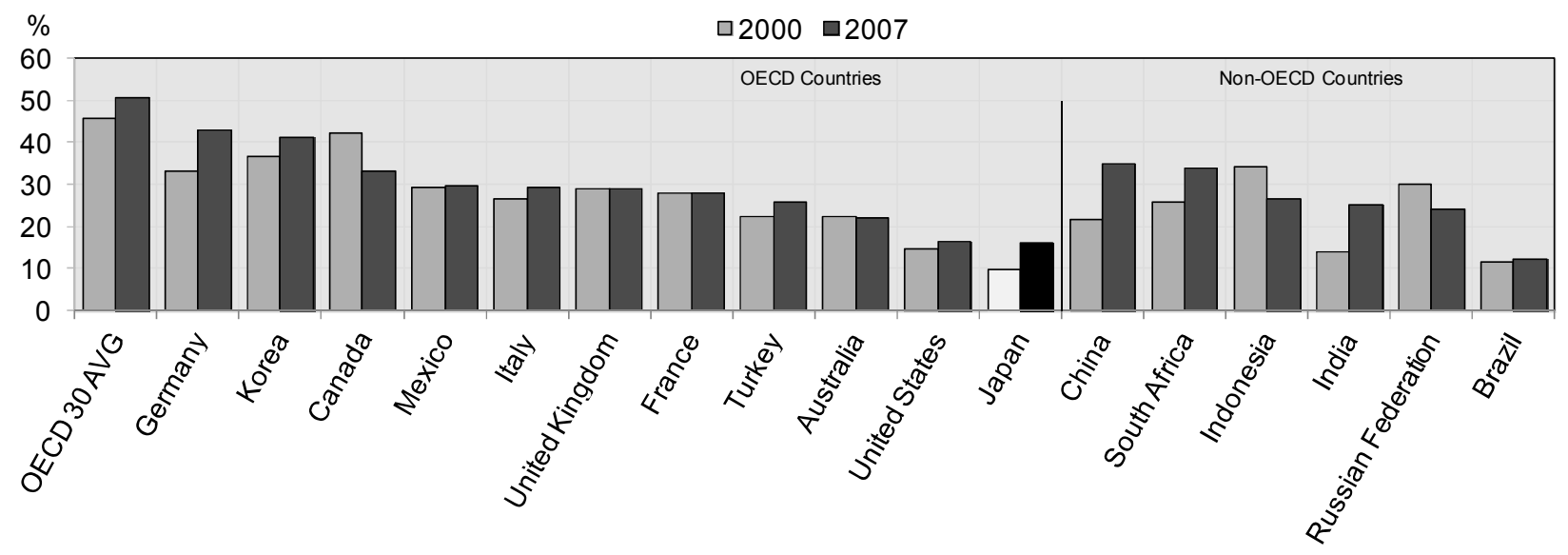

Figure A.3. World exports market shares in goods and services In percentage, at current prices

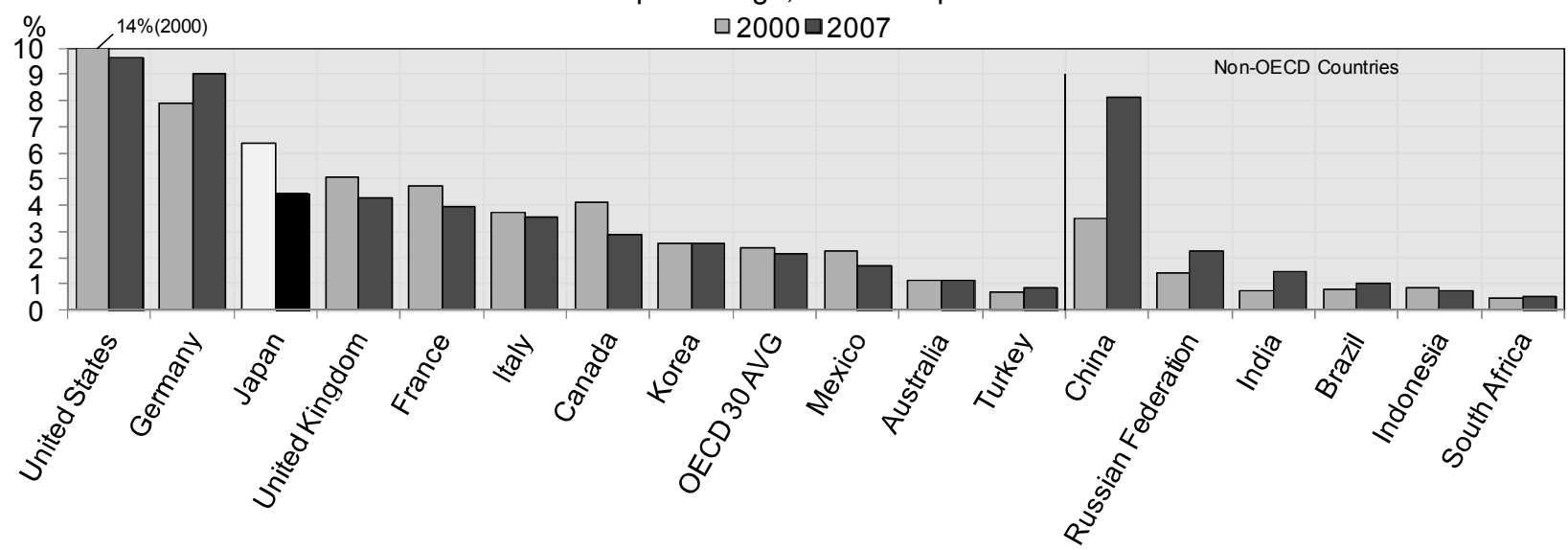

Source: OECD (2010a), OECD Economic Globalisation Indicators 2010. 


\section{B. INTERNATIONAL INVESTMENT}

Foreign direct investment (FDI) plays a fundamental role in international economic integration and is often among the most dynamic drivers of industrial restructuring. FDI outflows from Japan, i.e. foreign assets held by Japan, have shown a relatively stable pattern between 1990 and 2008, reflecting a long-term trend by Japanese companies to develop their activities abroad. However, Japanese outward FDI remains significantly lower than FDI outflows by other countries such as France, the United Kingdom, Germany and the United States (Figure B.1). As regards inward investments, i.e. liabilities of Japan to other countries, the figures for Japan are much lower relative to other countries (e.g. the United States, the United Kingdom, China), suggesting that Japan remains rather closed to foreign investment.

Mergers and acquisitions (M\&As) represent the most common form of FDI, much more than the creation of new businesses or the capacity expansion of existing firms. Enterprises engage in cross-border M\&As for several reasons: to strengthen their market position by expanding their businesses to other opportunities on the global market; to obtain a critical size in the world market; to exploit other firms' complementary assets such as innovations and technology; or to access other advantages such as company reputation, economies of scale, and brands or design.

Japan lags most of the other G-20 countries in terms of M\&As as a percentage of GDP; countries with a high activity in M\&A are the United Kingdom, Canada and Australia (Figure B.2). Outward flows of M\&A are relatively more important than inward M\&A for Japan, suggesting again the relatively closed nature of Japan to foreign investment.

The rather limited inflows of FDI and M\&A into Japan directly help explain the limited role of foreign affiliates in Japan. Both in manufacturing (3.1\% in 2007) and in services (1.4\% in 2006), the foreign share in turnover in Japan is far below the share in other OECD countries. Countries with a large foreign presence are Canada and the United Kingdom (Figure B.3).

\section{Foreign direct investment flows}

Foreign investment is said to be "direct" if the investor resident in another economy holds at least $10 \%$ of the ordinary shares or voting rights of the firm in which it has made the investment. The $10 \%$ threshold means that the direct investor is in a position to influence the management of the firm and to play a role in its affairs, without necessarily wielding control over the firm.

\section{Cross-border mergers and acquisitions}

A merger is an operation in which two or more companies decide to pool their assets to form a single company. In the process, one or more companies disappear completely. An acquisition does not constitute a merger if the acquired company does not disappear. Mergers are less frequent than acquisitions.

Cross-border mergers and acquisitions can either be inward or outward. Inward cross-border mergers and acquisitions imply an inward capital movement through the sale of domestic firms to foreign investors, while outward cross-border mergers and acquisitions imply an outward capital movement through the purchase of all or parts of foreign firms.

The data are taken from the Mergers and Acquisitions Global database (Dealogic). The definitions and methodology used for OECD's FDI statistics and Dealogic's M\&A statistics are not compatible. Therefore direct comparison between FDI and M\&A data used in the present document is not possible. However, M\&A data provide meaningful indicators to project FDI. 


\section{B. INTERNATIONAL INVESTMENT}

Figure B.1 Foreign direct investment assets and liabilities as a percentage of GDP Average 2005-2008

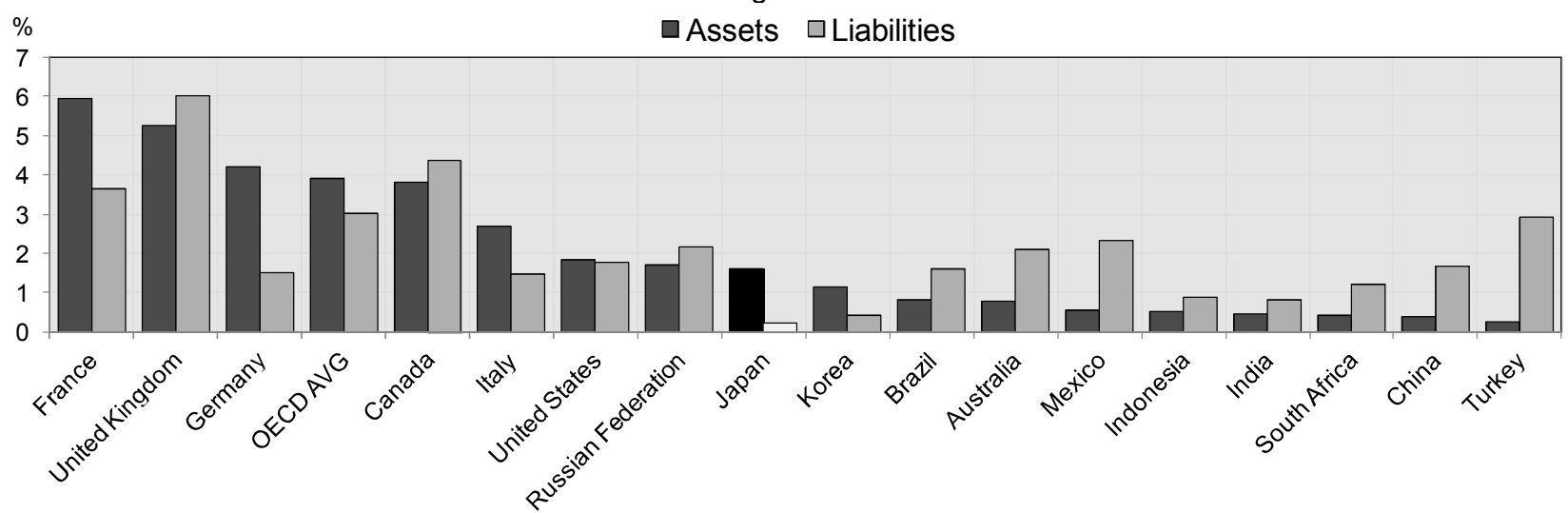

Figure B.2 Outward and inward cross-border mergers and acquisitions Average value as a percentage of GDP, 2006-2010

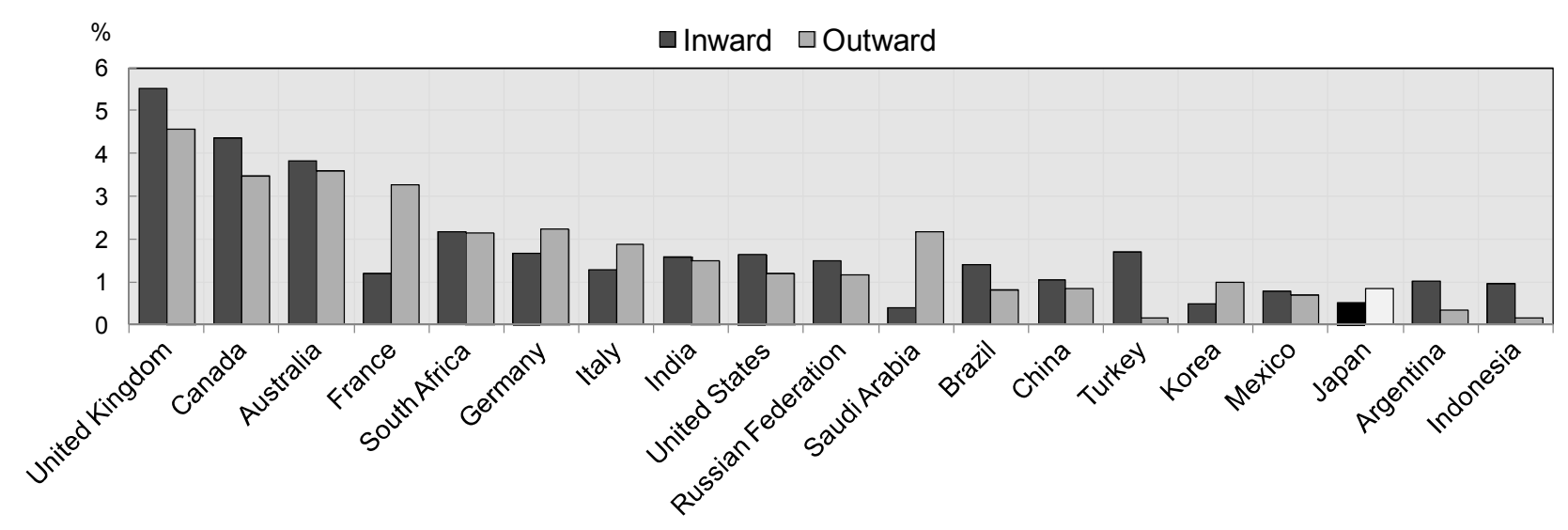

Figure B.3 Share of foreign-controlled affiliates in total turnover, 2007, in percentage

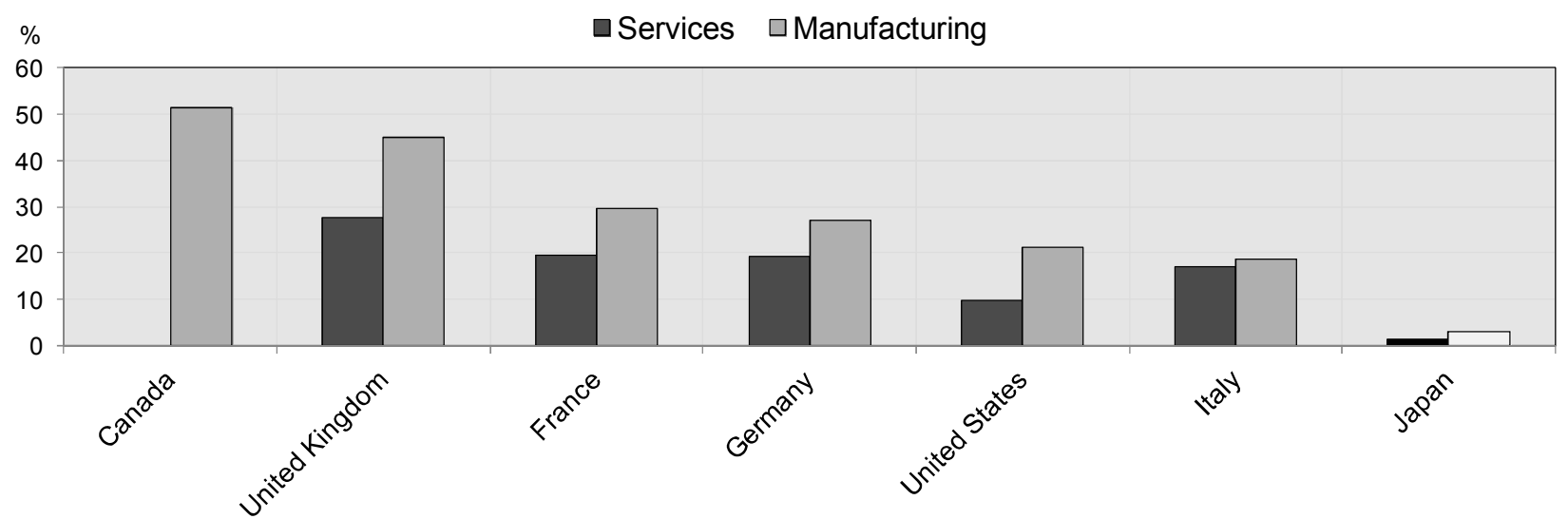

Source: OECD (2010a), OECD Economic Globalisation Indicators; Dealogic. 


\section{INTERNATIONAL TRADE AND INVESTMENTS, INDUSTRY LEVEL}

An analysis of openness to international trade and investments at the (manufacturing) industry level indicates that there is a large heterogeneity across industries, with some industries in Japan significantly less open than others (e.g. food, beverages and tobacco versus transport equipment). Differences largely depend on the structural characteristics of industries (transport costs, economies of scale, etc.), the organisation of industries at the global level and the international competitiveness of Japan.

Due to the high number of large Japanese companies in the automotive industry, Japan shows a large outbound activity in the sector of transport equipment; exports as well as investments abroad by Japanese MNEs (and FDI outflows to a lesser extent) are much higher than in other manufacturing industries. In the electronics industry, Japan has contributed to the important vertical specialisation that has taken place in Asia, with both imports (of final goods) and exports (of high value intermediate goods) being significant. In addition, also the activities by Japanese MNEs in other (Asian) countries are significant in the electronics industry. Both in the automotive and the electronics industry, Japan produces a large volume of parts and components for industries all over the world. The food and beverages industry seems to be the least internationalised in Japan, characterised especially by large imports.

The overall observation, when comparing Japan with other countries like the United States, the United Kingdom, Germany and Korea, confirms that the Japanese economy is rather closed. In almost all the presented industries the importance of international trade and investment (both inbound and outbound) is smaller for Japan. While the selected industries all belong to the manufacturing industry, other work suggests that the same observation applies to the services industry.

Figure C.1 Food, beverages and tobacco

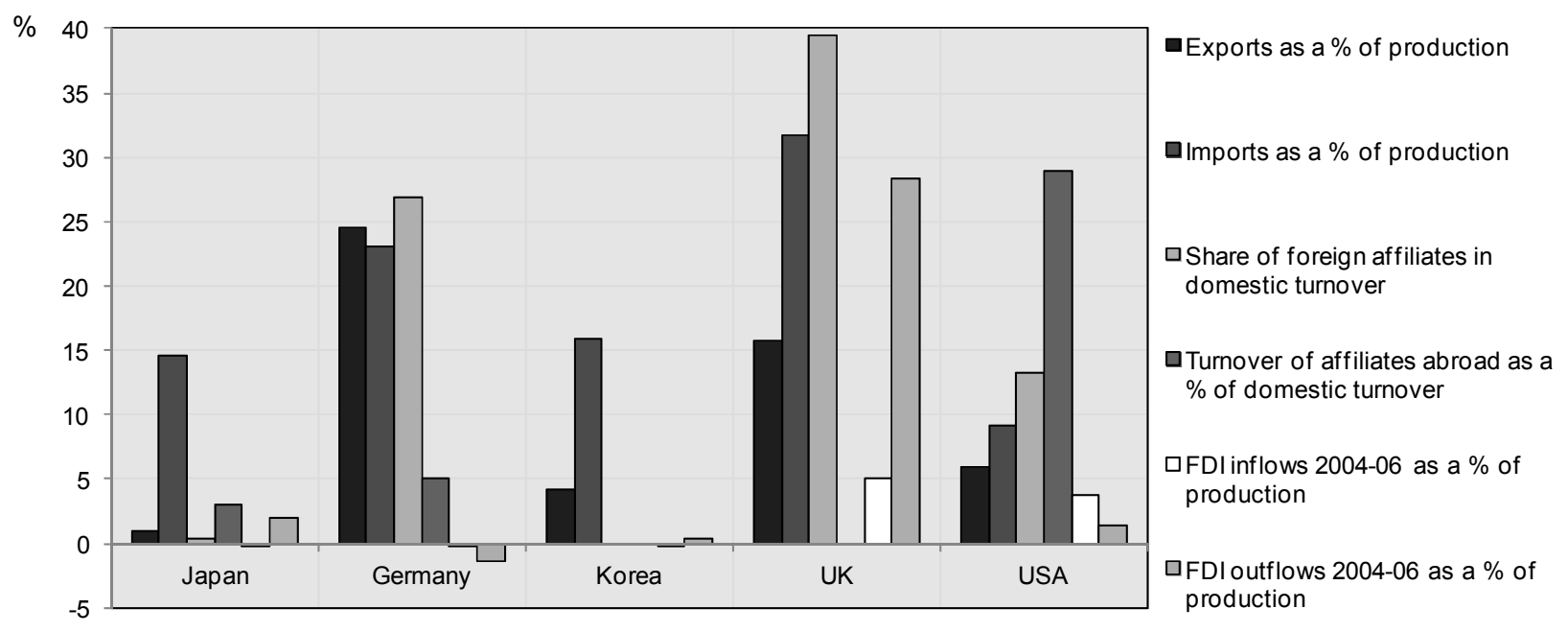

Note: data on affiliates are not available for Korea and the United Kingdom (affiliates abroad). For the United States, domestic production has been used as a proxy for domestic turnover.

Source: OECD calculations based on OECD AFA, STAN and International Direct Investment databases. 


\section{INTERNATIONAL TRADE AND INVESTMENTS, INDUSTRY LEVEL}

Figure C.2 Machinery and equipment (ISIC 29)

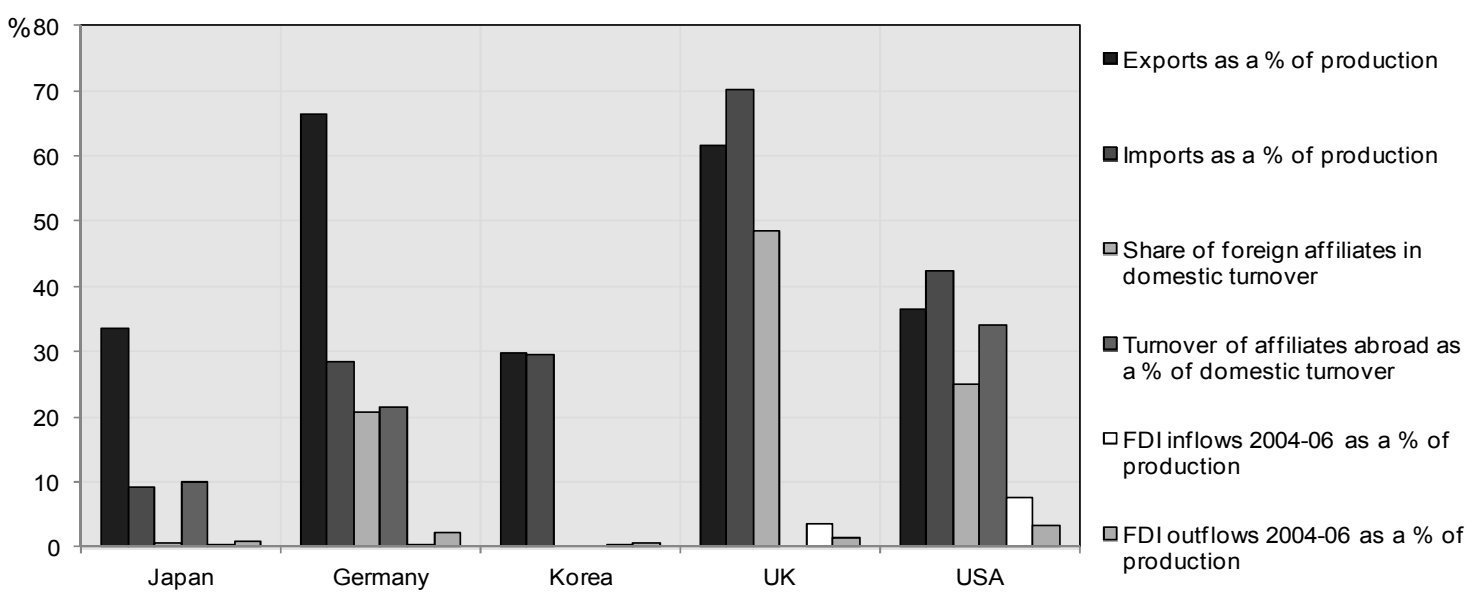

Figure C.3 Computers, radio, TV, and telecommunication equipment (ISIC 30+32)

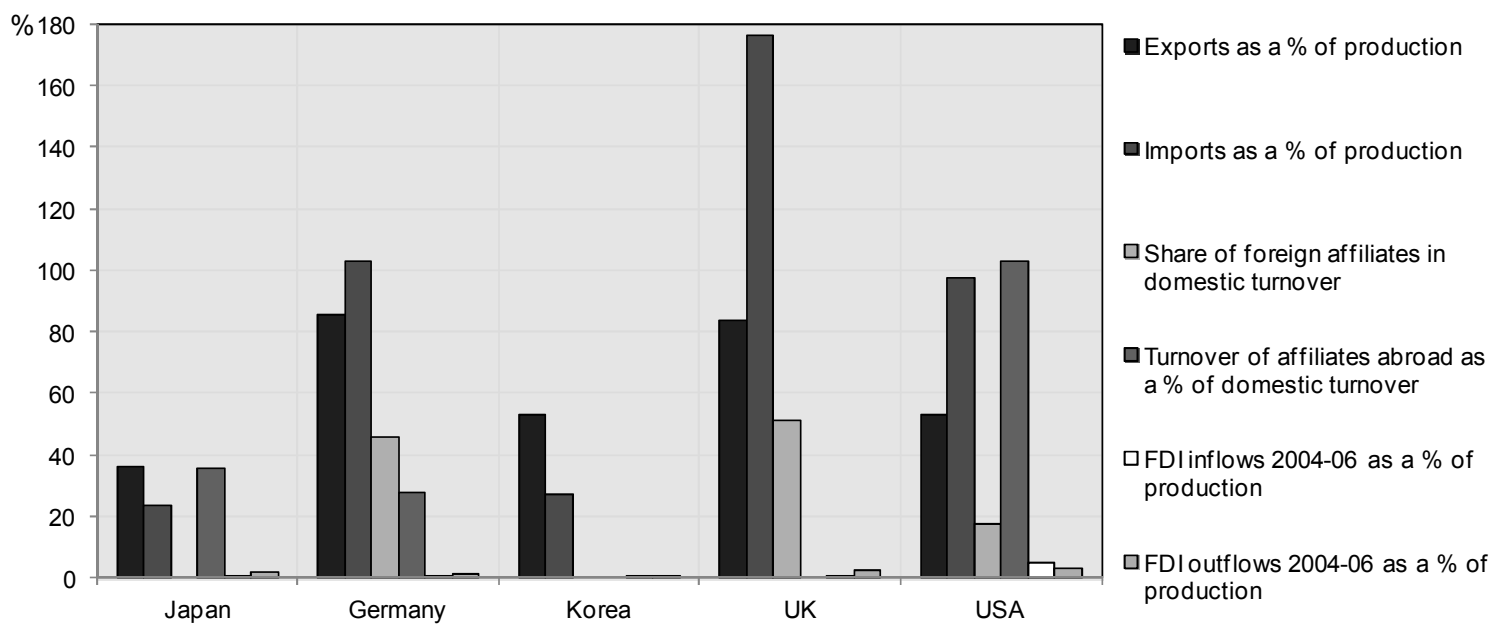

Figure C.4 Transport equipment (ISIC 34+35)

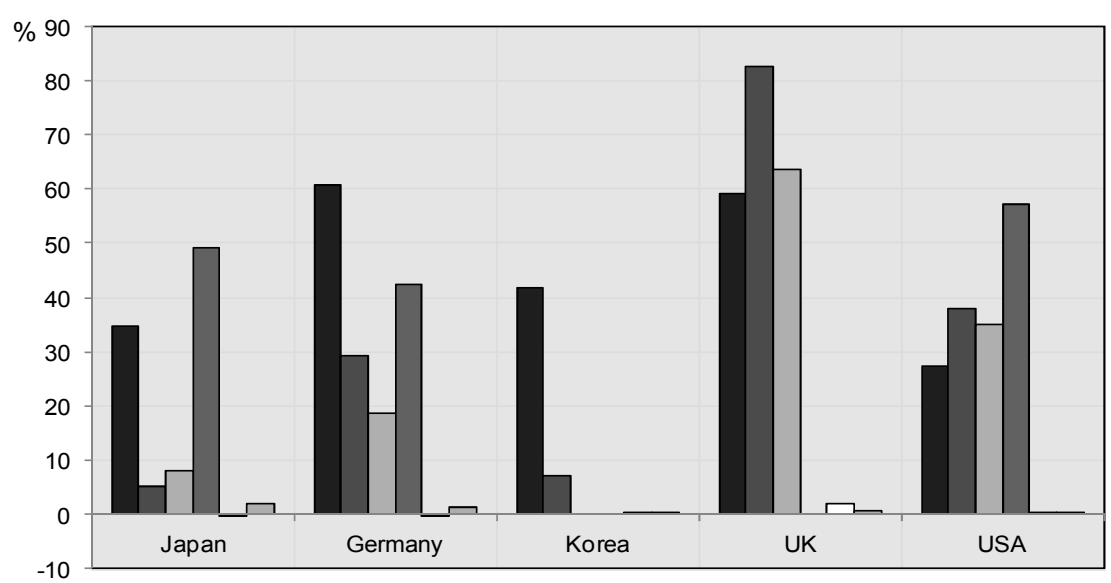

Exports as a \% of production
Imports as a \% of production
口 Share of foreign affiliates in
domestic turnover
प Turnover of affiliates abroad as
a \% of domestic turnover
口FDI inflows $2004-06$ as a \% of
production
口FDI outflows $2004-06$ as a \% of
production

Note: data on affiliates are not available for Korea and the United Kingdom (affiliates abroad). For the United States, domestic production has been used as a proxy for domestic turnover.

Source: OECD calculations based on OECD AFA, STAN and International Direct Investment databases. 


\section{GLOBAL VALUE CHAINS}

The internationalisation of value chains is central to the current globalisation process, and has resulted in a growing international fragmentation of production. Different stages in the production process are located across different economies and intermediate inputs like parts and components are produced in one country and then exported to other countries for further production and/or assembly in final products. Companies restructure their activities on a global scale, including by engaging in outsourcing and offshoring, in search for lower costs, enhanced efficiency, new markets, etc.

Some aggregate measures clearly show the increasing importance of global value chains (GVCs) and the position of countries in these cross-border chains. First, there is a general trend towards a decline in "production depth" in most OECD countries. The decreasing share of value added in production directly reflects the larger use of intermediate inputs in the production process. Japan reported a higher share of value added in production in 2006 than in 1990 (Figure D.1). This may reflect the fact that Japan is not as fully integrated in GVCs as other OECD countries, although other indicators do not really confirm this rather surprising finding.

Second, countries increasingly source intermediates internationally, more than from domestic suppliers. The ratio of imported to domestic inputs has increased significantly between 1995 and 2005 in most countries including Japan (Figure D.2). Smaller countries import relatively more intermediates from abroad which is consistent with their limited size and their typically larger international orientation.

Third, the importance of intra-industry trade is increasing. A significant part of this increase can be explained by the simultaneous growth of exports and imports within the same industry following the development of GVCs. Parts of products are manufactured in one country and then exported to (imported by) other countries as inputs in the next production steps. The value of this indicator is again lower for larger countries, though particularly for Japan (Figure D.3).

\section{The measurement of intra-industry trade}

Intra-industry trade flows are conventionally defined as the two-way exchange of goods within standard industrial classifications. The extent of intra-industry trade is commonly measured by Grubel-Lloyd indexes based on commodity group transactions. Thus, for any particular product class $\mathrm{i}$, an index of the extent of intra-industry trade in the product class $i$ between countries $A$ and $B$ is given by the following ratio:

$$
I I T_{i . A B}=\left(\frac{\left(X_{i}+M_{i}\right)-\left|X_{i}-M_{i}\right|}{\left(X_{i}+M_{i}\right)}\right) \bullet 100
$$

This index takes the minimum value of zero when there are no products in the same class that are both imported and exported, and the maximum value of 100 when all trade is intra-industry (in this case $\mathrm{Xi}$ is equal to $\mathrm{Mi}$ ). 


\section{GLOBAL VALUE CHAINS}

Figure D.1 Value added as a percentage of production, 1990 and 2008

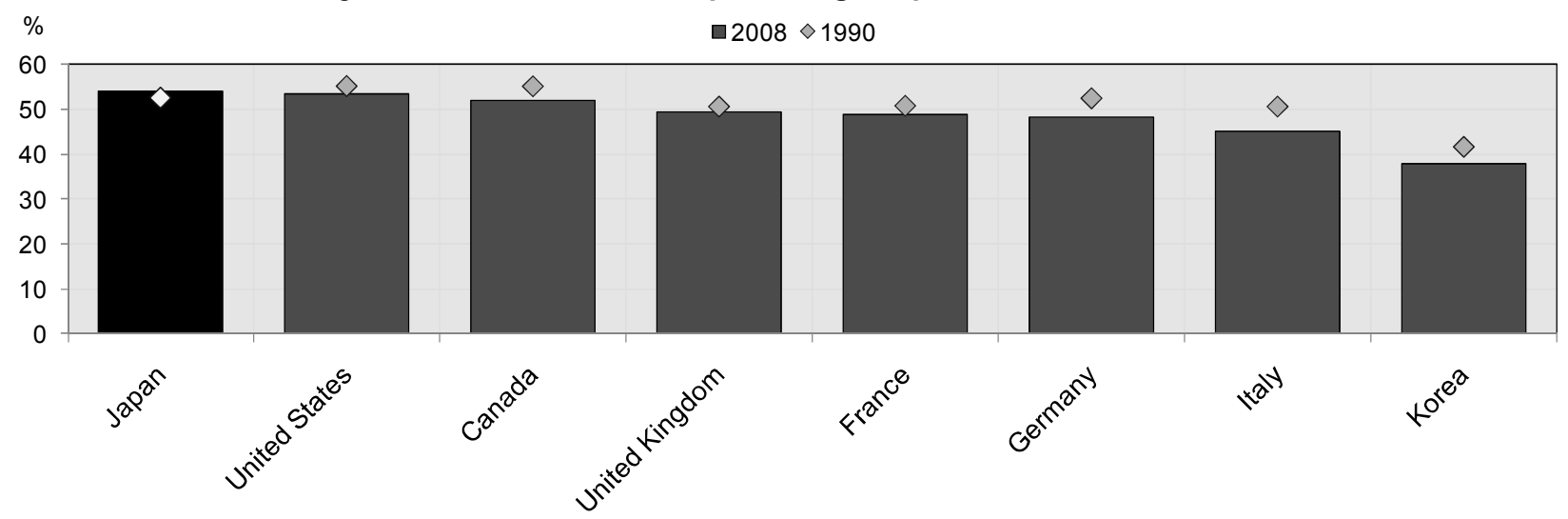

Figure D.2 Imported intermediates as a share of total intermediates

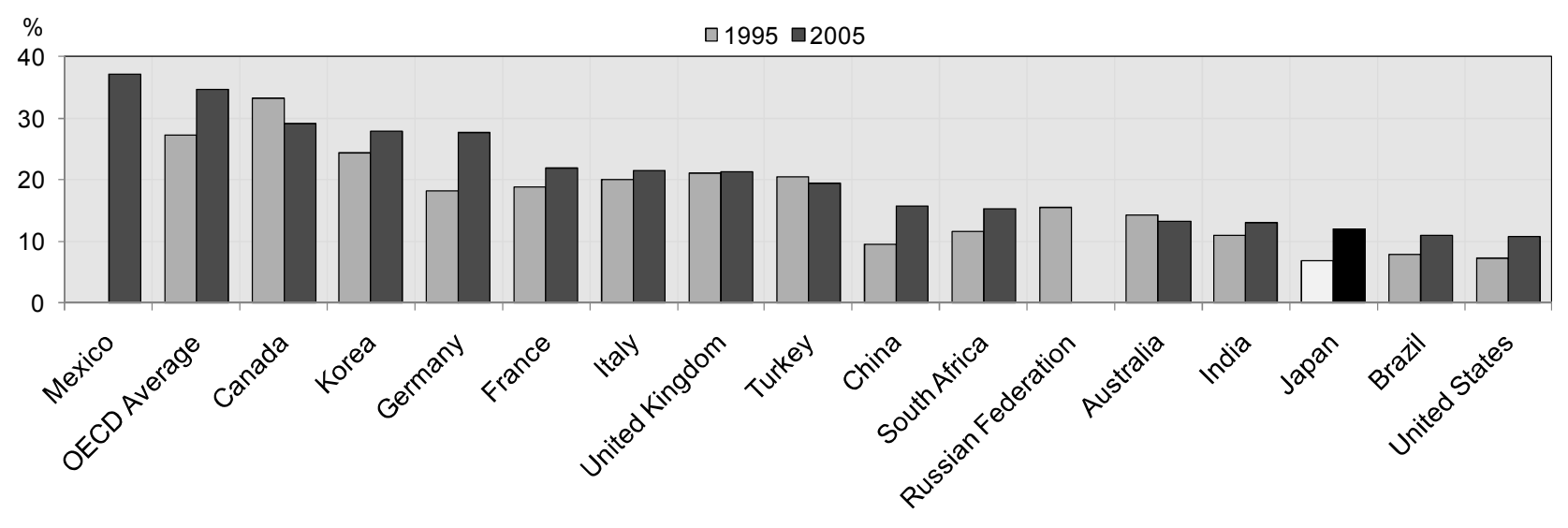

Figure D.3 Index of intra-industry trade in manufactures Average 1997-2008

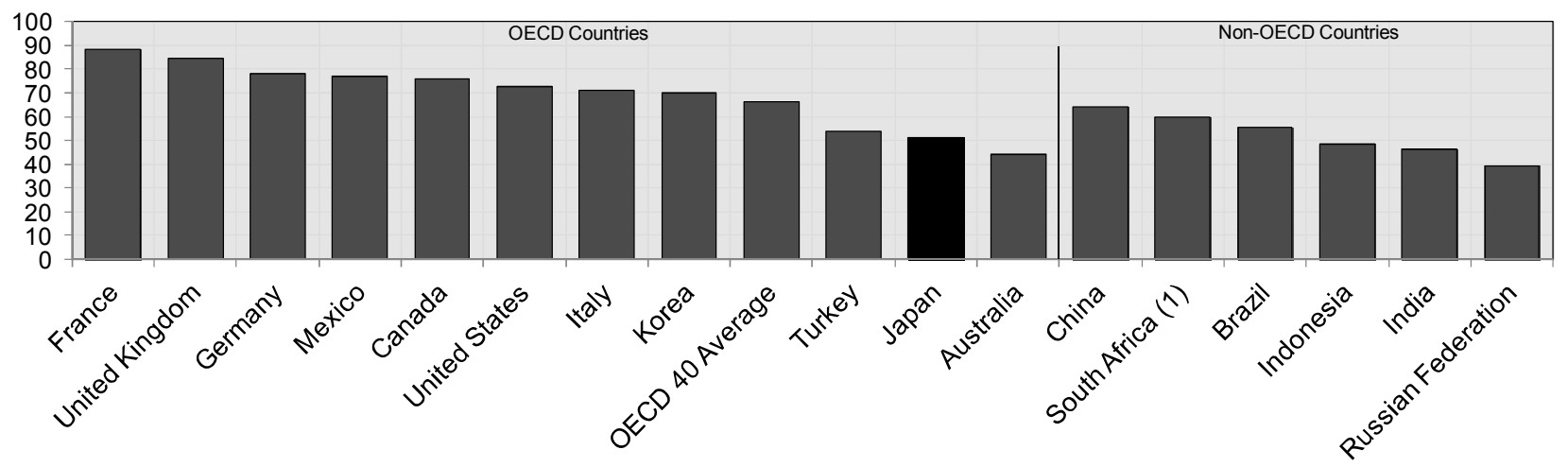

1. 2000 - 2008 for South Africa.

Source: OECD (2010a), OECD Economic Globalisation Indicators 2010. 


\section{GLOBAL VALUE CHAINS (CONTINUED)}

The increasing importance of imported intermediates is directly related to the growing offshoring of activities by companies. Smaller countries show again a higher dependence on international activities, while larger countries like the United States and Japan show a lower degree of offshoring both in services and manufacturing. While international sourcing of intermediates remains on average more important in manufacturing, the emergence of GVCs increasingly also affects services sectors (Figure D.4).

Exports are increasingly dependent on imported intermediate inputs; the import content of exports represented on average 23\% of trade among OECD countries in 2005 (Figure D.5). Japan was no exception to this trend, with the import content of exports growing from $8 \%$ in 1995 to $15 \%$ in 2005 , though it is still among the OECD countries with the lowest shares. The increase in the import content of exports is particularly clear in countries with a high multinational presence. Foreign affiliates in different host countries produce intermediates that are then exported to final consumers, but also to other affiliates and to the headquarters of the multinational company.

Countries source intermediates and incorporate them in their exports to a larger degree from neighbouring countries, and this is related to the importance of distance and trade costs for such vertically integrated trade. The import content of exports of European countries is heavily based on trade with other European countries, with similar regional dependencies existing within the NAFTA region and East Asia. Japan sources a large part of its intermediates embodied in exports within the region (Figure D.6), while Japan is also an important producer of intermediates towards other East Asian countries. A triangular trade pattern has developed in East Asia, with parts and components being produced by Japan, Chinese Taipei and Korea and then exported to emerging economies such as China, where they are assembled into finished products. Finally, they are re-imported by Japanese firms or exported to other developed regions.

\section{Index of offshoring and outsourcing abroad}

The index of outsourcing abroad $\left(O I_{i}\right)$ is constructed as follows:

For a sector $i$ and for a set of goods and services $j$, the index of outsourcing $\left(O I_{i}\right)$ is:

$$
O_{i}=\sum_{j}\left[\frac{\text { purchases of inputs } j \text { by industry } i}{\text { total inputs used by industry } i}\right] \cdot\left[\frac{M_{j}}{D_{j}}\right]
$$

where ${ }^{M_{j}}$ are the imports of goods or services ${ }^{j}$ and is the domestic demand ${ }^{D_{j}}$ for goods or services ${ }^{j}$

where

$$
D_{j}=Y_{j}-X_{j}+M_{j}
$$

with $Y_{j}$ is the production of goods or services $j$ and $X_{j}$ are the exports of goods or services $j$

In other words, the more imports of goods or services $\mathrm{j}$ are purchased by industry $\mathrm{i}$ as input for its production, the more the outsourcing of industry $i$ is important.

\section{Import content of exports}

The import content of exports can be calculated as the foreign value added embodied in exports:

$$
\begin{aligned}
& =\text { Imported intermediates } x \text { (exports/gross output) } \\
& =u \text { * Am * (I-Ad)-1 }{ }^{*} \mathrm{X} / \mathrm{Xk}
\end{aligned}
$$

where Am and Ad contain the input-output coefficient for imported and domestic transactions respectively; $u$ denotes an $1 \times \mathrm{n}$ vector each of whose components is unity, the matrix $\mathrm{X}$ is an $\mathrm{n} \times 1$ vector of exports and $\mathrm{Xk}$ is total country exports. The calculation is based on bilateral trade data and Input-Output tables. 


\section{GLOBAL VALUE CHAINS (CONTINUED)}

Figure D.4 Offshoring of manufacturing and services, by country, 2005

Imported intermediates as share of total intermediates

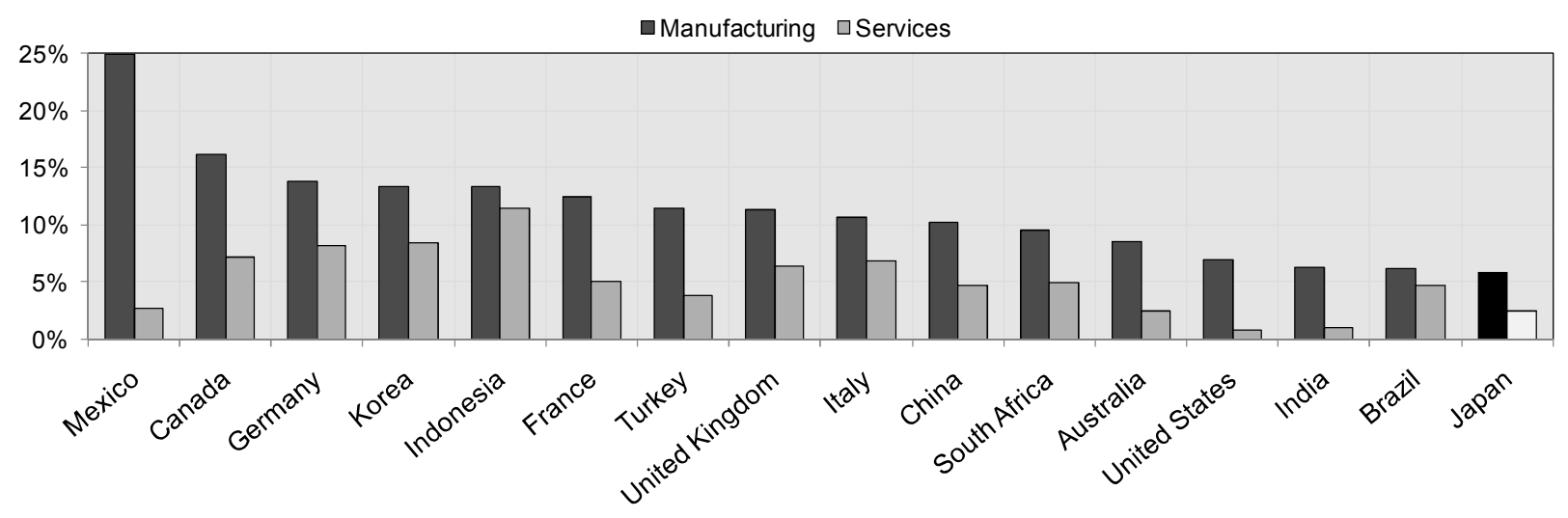

Figure D.5 Import content of exports, by country

Percentage of exports (directly and indirectly) based on imported intermediates

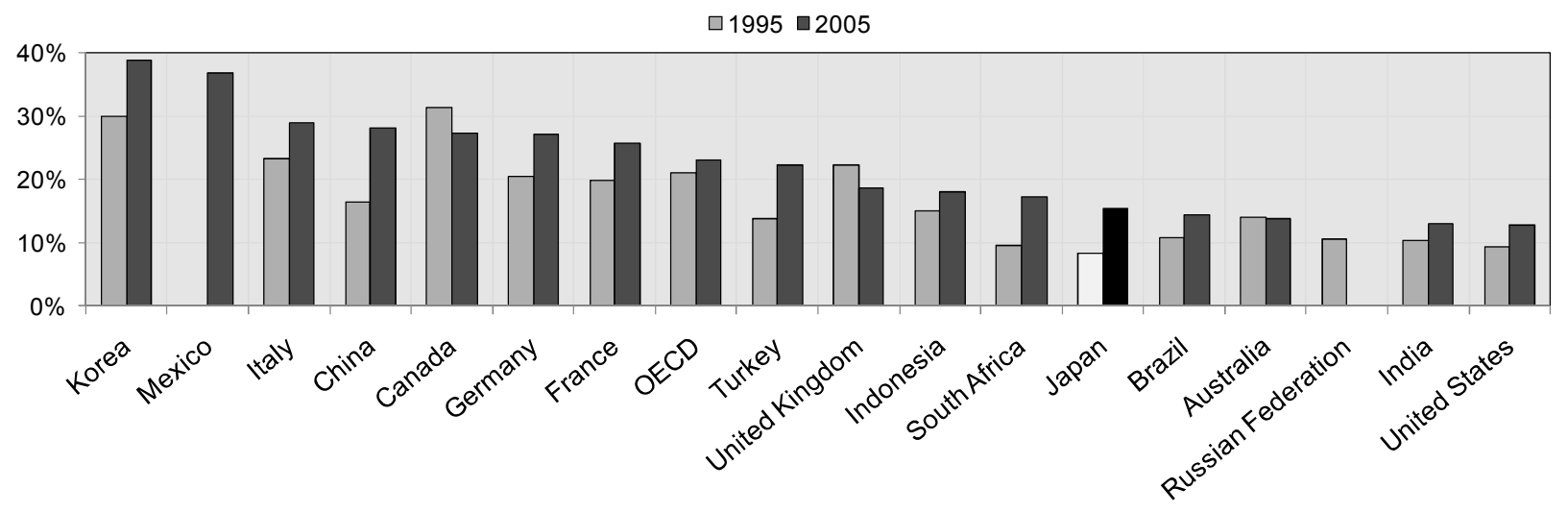

Figure D. 6 Import content of exports with partner countries, 2005

Percentage of exports (directly and indirectly) based on imported intermediates, by origin

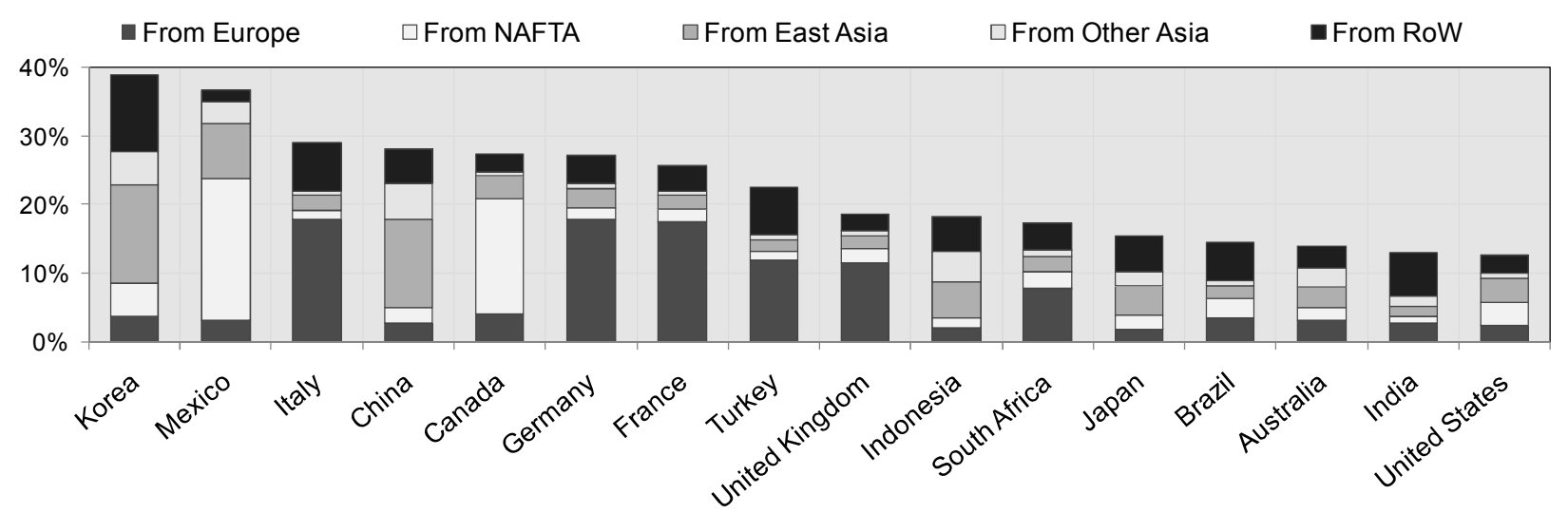

Source: OECD (2010a), OECD Economic Globalisation Indicators 2010. 


\section{E. INTERNATIONALISATION OF KNOWLEDGE}

Knowledge and technology have also become increasingly global, mainly because of the large number of countries that invest in knowledge. Recently, emerging countries such as China and India have become important investors in R\&D and technology. In addition, knowledge is increasingly observed to flow across borders: for example, Business Research and Development (R\&D) is increasingly financed by funds from abroad. In a large number of countries (e.g. the United Kingdom, Canada, etc.), 10\% or more of aggregate business R\&D is nowadays funded from abroad. In contrast, the contribution of foreign sources to business R\&D in Japan is limited (Figure E.1).

Foreign sources of R\&D include businesses, public institutions or international organisations. Foreign affiliates of MNEs play a particularly important role in national R\&D investments: in countries like the United Kingdom and Canada these firms account for more than $25 \%$ of total business investment in R\&D. In the process of internationalisation, firms are increasingly looking for new technological competencies, adaptation to markets and lower R\&D costs and hence expand their research activities overseas. Largely reflecting the limited importance of foreign affiliates, the share of foreign affiliates in total R\&D expenditures in Japan was about 5\% in 2007, much lower than the other countries for which data are available (Figure E.2).

Another dimension of the internationalisation of knowledge and technology is reflected in the technology balance of payments, which measures disembodied technology transfers like licence fees, patents, purchases and royalties paid, know how, research and technical assistance. Technology receipts as well as payments increased during the past decade in most countries including Japan. Nevertheless, the significance of these technology flows (incoming as well outgoing) remained more limited for Japan, particularly in comparison with Germany and United Kingdom (Figure E.3). Japan has an important trade surplus in this area, indicating it received more from technology than it paid to other countries.

\section{Measuring flows of R\&D funds}

R\&D involves significant transfers of resources between units, organisations and sectors. In order to better measure and evaluate innovation policies and globalisation, it is important to trace the flow of R\&D funds. According to the Frascati Manual, these transfers may be measured in two ways.

One is performer-based reporting of the sums which one unit, organisation or sector has received or will receive from another unit, organisation or sector for the performance of intramural R\&D during a specific period.

The second is source-based reporting of extramural expenditures. These are the sums a unit, organisation or sector reports having paid or committed to pay to another unit, organisation or sector for the performance of R\&D during a specific period. The first of these approaches is strongly recommended.

For such a flow of funds to be correctly identified, two criteria must be fulfilled:

- There must be a direct transfer of resources.

- The transfer must be both intended and used for the performance of R\&D.

For further details on the identification of these criteria, see the Frascati Manual. 


\section{E. INTERNATIONALISATION OF KNOWLEDGE}

Figure E.1 Funds from abroad as a percentage of business enterprise R\&D, 2007

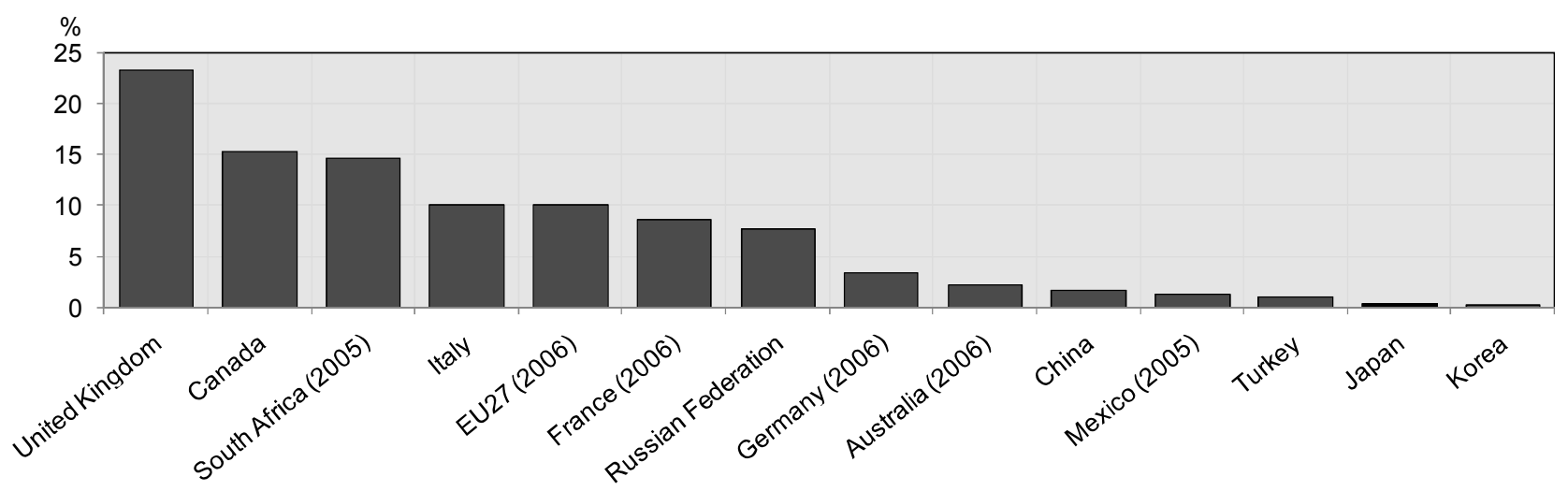

Figure E.2 Share of foreign-controlled affiliates in total business sector R\&D expenditure, 2007

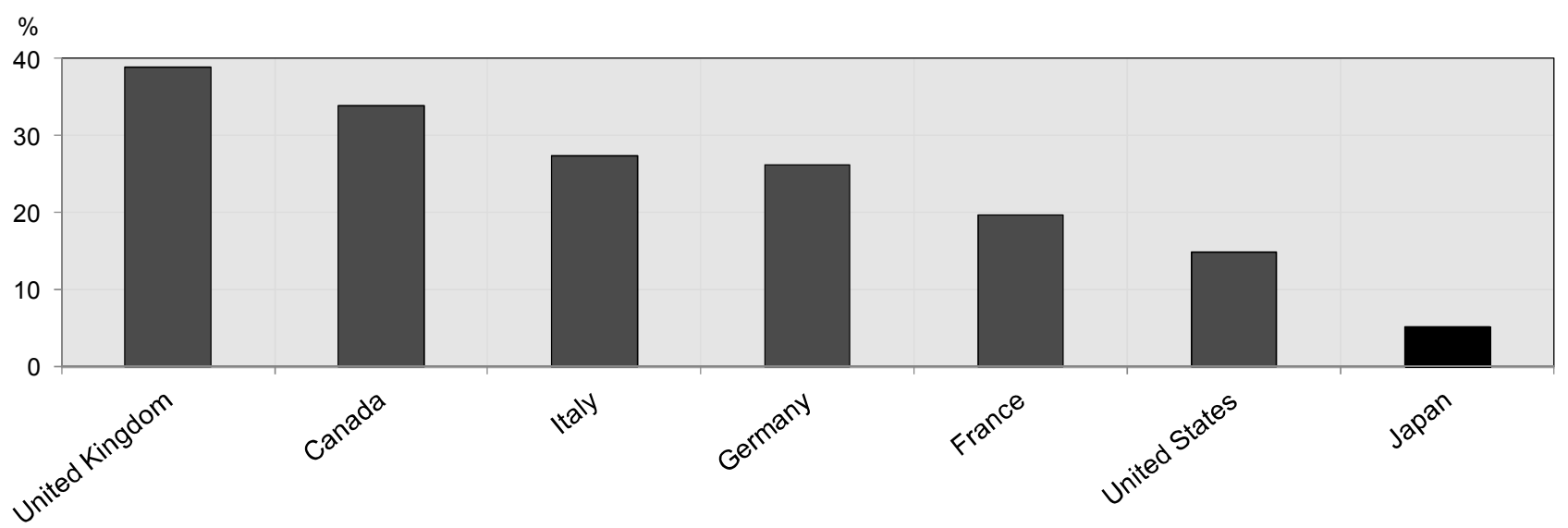

Figure E.3 Technology flows as a percentage of GDP, 2008

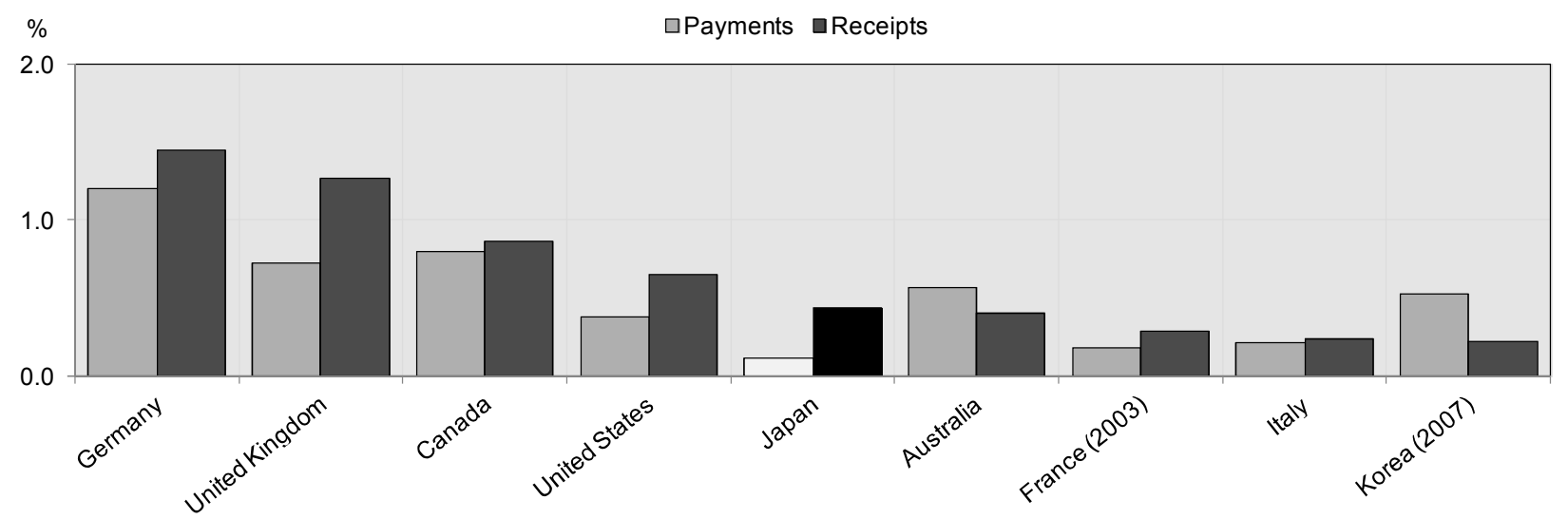

Source: OECD (2010a), OECD Economic Globalisation Indicators 2010. 


\section{E. INTERNATIONALISATION OF KNOWLEDGE (CONTINUED)}

Internationalisation of knowledge extends beyond R\&D and technology payments. Indicators of coauthorship measure how knowledge is created among researchers and how collaboration in research is changing. National and international co-authorships have grown strongly over the past years and have become more important than single authorship. While in several countries national and international coauthorship are equally important, national co-authorship is three times as important as international coauthorship in Japan (Figure E.4). Researchers in Germany, the United Kingdom and the United States engage in the largest number of international collaborations when taking into account the absolute number of scientific articles.

Cross-border ownership of patents, both foreign ownership of domestic inventions (inward) as well as domestic ownership of inventions made abroad (outward), also point to the growing internationalisation of technological activities and the circulation of knowledge among countries. Collaboration with foreign partners increasingly plays an important role in allowing domestic actors to gain access to a broader pool of resources and knowledge at lower cost and to share risks with partners. On average, $15 \%$ of all inventions were owned or co-owned by foreign residents in 2005-07, with smaller open economies typically reporting higher shares. Korea and Japan report the lowest shares of foreign ownership in 200507 with $3.9 \%$ and $4 \%$, respectively, indicating the limited importance of foreign firms controlling domestic inventions in these countries (Figure E.5). Japan also ranks far below other countries in the number of inventions made abroad, but controlled by domestic firms.

Collaboration on innovation with foreign partners is another important source of knowledge internationalisation: it can take a variety of forms with different levels of interaction ranging from simple one-way information flows to highly interactive and formal arrangements. Collaboration with foreign customers and/or suppliers helps firms develop new products, processes or other innovations. While the data for Japan are relatively old (1999-2001), they suggest a rather limited degree of international collaboration in technology by Japanese firms. Instead Japanese firms show a clear preference for cooperating with other Japanese firms (Figure E.6). Countries like China, Korea and Australia show the same pattern, while European countries' firms tend to engage more in collaboration with firms abroad, though mainly within other European countries.

\section{Cross-border ownership of inventions}

Patent documents report the inventor(s) and the applicant(s) - the owner of the patent at the time of application - along with their addresses and countries of residence. A difference between the owners' and inventors' country of residence points to cross-border ownership of inventions. In most cases, cross-border ownership of inventions is mainly the result of activities of multinationals: the applicant is an international conglomerate and the inventors are employees of a foreign subsidiary.

Foreign ownership of domestic inventions is one of the measures of globalisation of technological activities. It refers to the number of patents invented domestically and owned by non-residents in the total number of domestic inventions. It measures the extent to which foreign firms control domestic inventions. Obviously, what is considered foreign ownership in one inventor country implies a domestically owned invention abroad by firms in another country. Foreign ownership includes inventions in which the inventor country shares ownership (co-owned inventions), but this share is frequently a small part of the total of cross-border inventions.

Domestic ownership of inventions made abroad measures the extent to which domestic firms control inventions made by residents of other countries. It refers to patents that are the property of a country, but have at least one inventor located in a foreign country.

The use of patent indicators to measure globalisation of technology is not without shortcomings. Most of the caveats are related to the identification of companies' country of origin. The first caveat concerns the financial context of the cross-border ownership. A patent invented abroad may mean an acquisition or merger rather than the setting up of a R\&D laboratory. Patent databases do not register such changes in the ownership of patents. A second problem concerns the origin of subsidiaries. In some cases, the owner country reported may be not the country in which the company's headquarters are located but that of the subsidiary in charge of management of international intellectual property. In other cases, the company owning the invention may be the subsidiary and the address reported that of the host country (and not that of the headquarters). 


\section{E. INTERNATIONALISATION OF KNOWLEDGE (CONTINUED)}

Figure E.4 Scientific articles by type of collaboration, 2008, measured as articles per capita

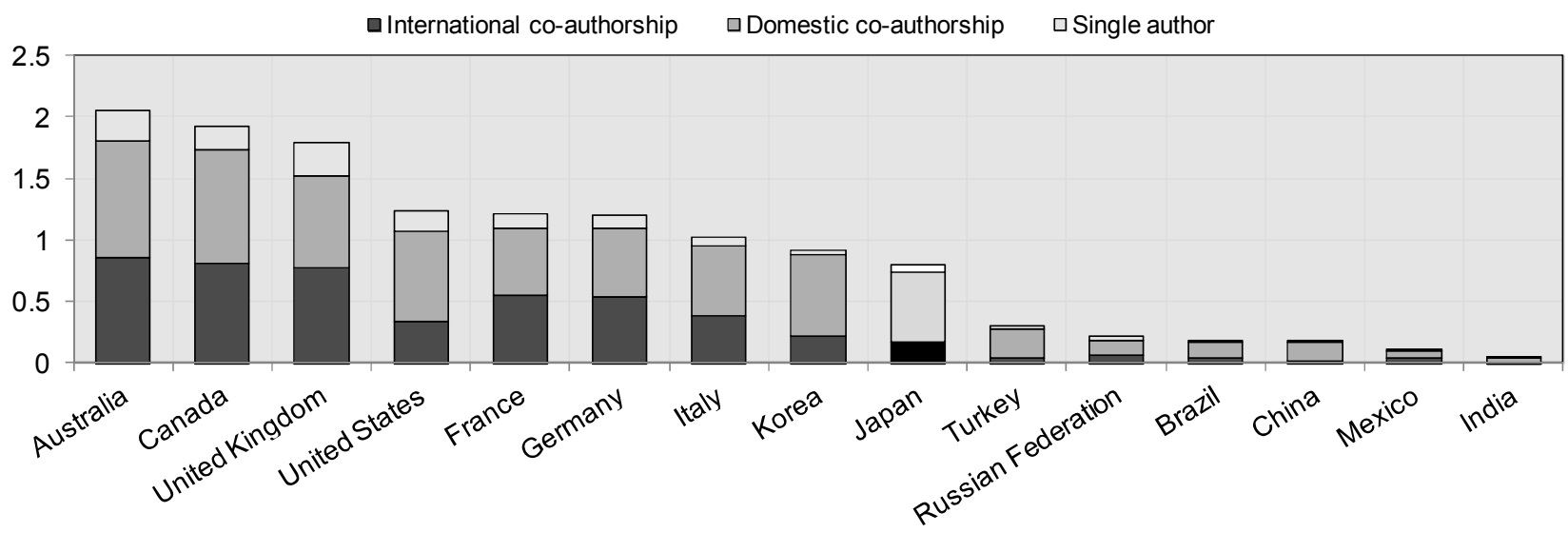

Figure E.5 Cross-border ownership of inventions, 2005-07

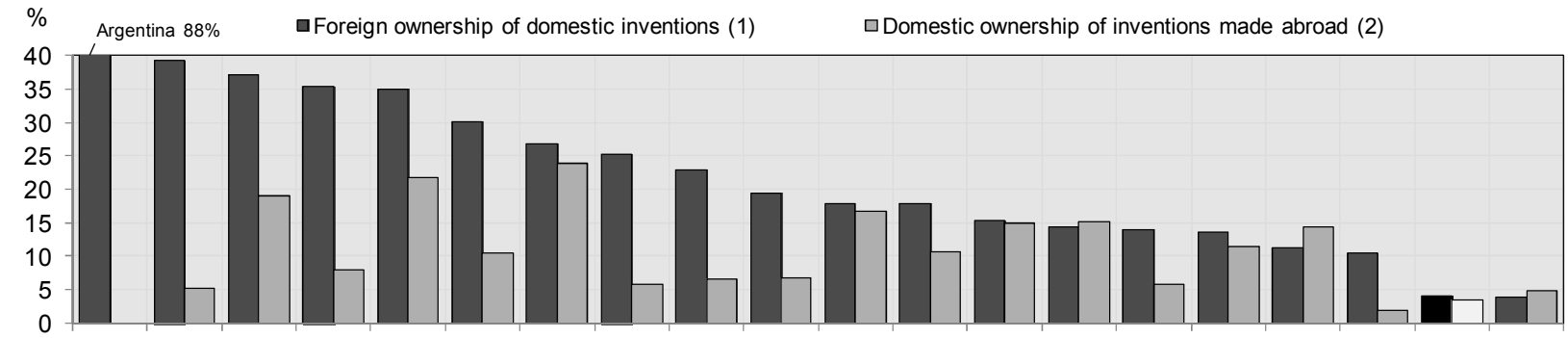

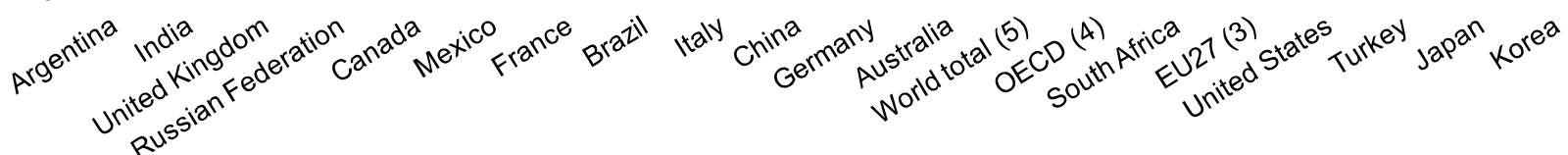

1. Share of PCT patent applications owned by foreign residents in total patents invented domestically. Coverage: countries/economies with more than $200 \mathrm{PCT}$ filings over the period. 2. Share of PCT patent applications invented abroad in total patents owned by country residents. Coverage: countries/economies with more than 200 PCT filings over the period. . All patents that involve international co-operation.

5. The $E U$ is teated on

Figure E.6 Firms with national/international collaboration on innovation, 2004-06
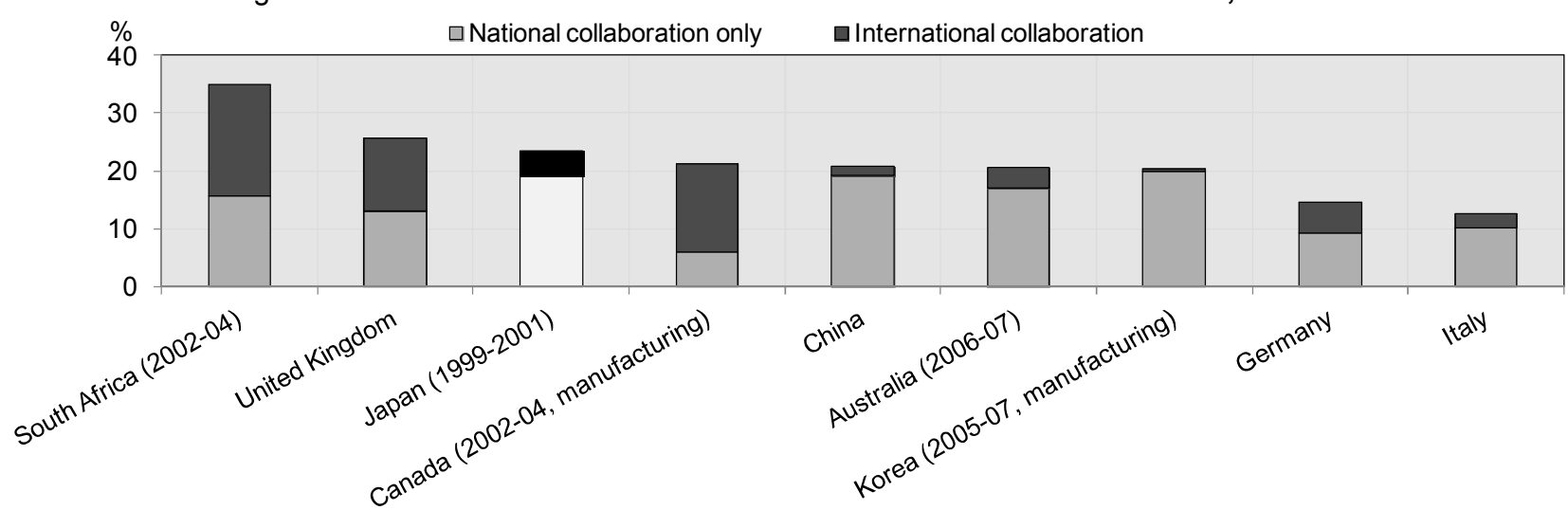

Source: OECD (2010b), Measuring Innovation: A New Perspective; OECD (2010a), Economic Globalisation Indicators 2010. 


\section{F. INTERNATIONALISATION OF LABOUR}

The process of globalisation has led to a significant increase in the volume and extent of international migration. In 2005, the world stock of migrants was estimated at 190 million people (United Nations, 2007 ); in Japan, the number of registered foreigners increased by $3 \%$ to 2.2 million in 2008 , and represented about $1.7 \%$ of the population. Inbound and outbound flows of persons to and from Japan are significantly lower than for other countries, however; rates of immigration as well of emigration for countries like United States, Australia and Canada are much higher (Figure F.1).

A large part of the migrant population moves from one country to another in search of new labour opportunities. Japan appears to have the lowest stock of foreign labour force among the countries for which data are available; the share of foreign persons in the total labour force increased from $0.23 \%$ in 2000 to $0.32 \%$ in 2008 (Figure F.2). Countries like France, Germany and the United Kingdom have a much higher share of foreign labour force.

The significantly smaller inflows of foreigners into Japan are also reflected in the nationality diversity index, capturing the diversity of residents in Japan in terms of nationality (Figure F.3). Japan but also Korea, have low levels for this index, especially compared with other countries like Australia, United States and Canada. This index points to the low diversity of the population (and hence one can also assume the labour force) in Japan with relatively few people coming from a smaller number of countries. According to the Immigration Bureau of Japan, the principal groups of foreign origin in Japan are: Chinese (29.6\%), Koreans (26.6\%) and Brazilians (14.1\%).

\section{Nationality diversity index}

Following the literature on ethnic diversity, an index of nationality diversity has been computed in order to get an idea of how diverse the population (and hence the labour force) is in different countries. This index includes native born as well as foreigners, although there are some differences between countries (foreigners vs. foreign born, see below).

The Nationality diversity index is defined as $d i v_{c t}=1-\sum_{i=1}^{M}\left(\mathrm{CoB}_{i}^{c}\right)_{t}^{2} ;$ where $\mathrm{COB}{ }_{i}^{c}$ is the share of people born in country i among the residents of country $\mathrm{c}$ in year $\mathrm{t}$.

Since data based on the country of birth are not available, a citizenship-based definition of migration is used. The immigrants are assumed to be individuals living in Japan and not holding Japanese nationality. This definition has obvious shortcomings:

- $\quad$ First, while there is an overlap between foreigners and the foreign-born, there is generally a significant difference between the two population figures;

- Second, the difference between foreigners and foreign-born applies not only to the absolute numbers, but also to the distribution of demographic and labour market characteristics. This implies that the Japanese data are not directly comparable with those of other countries.

Sources:

- United Nations Department of Economic and Social Affairs, Population Division (2007), World Population Prospects: The 2006 Revision.

- $\quad$ Aghion, P. and P. Howitt (2009), The Economics of Growth, Cambridge, MA: The MIT Press.

- $\quad$ Mauro P. (1995), Corruption and Growth, The Quarterly Journal of Economics, Vol. 110 (3), pp. 681-712.

- Ottaviano, G.I. and G. Peri (2006), "The economic value of cultural diversity: evidence from US cities", Journal of Economic Geography 6 (2006), pp. 9-44. 


\section{F. INTERNATIONALISATION OF LABOUR}

Figure F.1 Total Migration Rates ${ }^{1}$, circa 2000

Number of immigrants and emigrants as a share of total domestic population

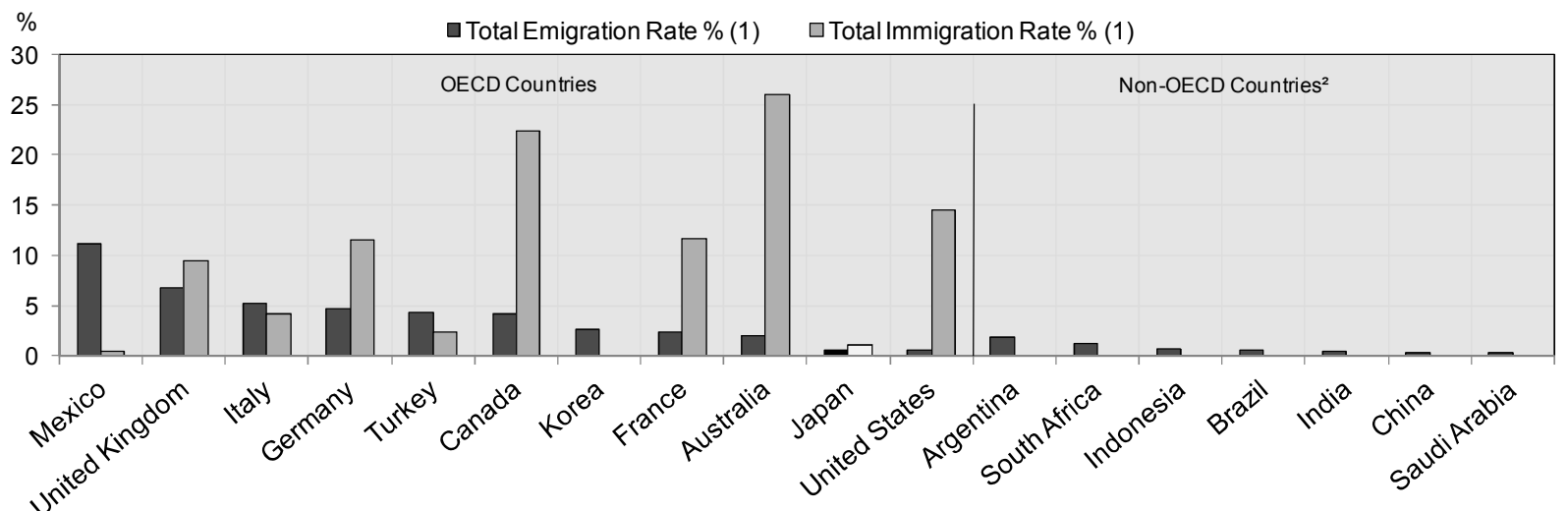

1. Including foreign-born persons in the population of the country of origin. 2. For Non-OECD countries and Korea, immigration rates are not available.

Figure F.2 Stocks of foreign labour force in OECD countries

As a share of total domestic labour force

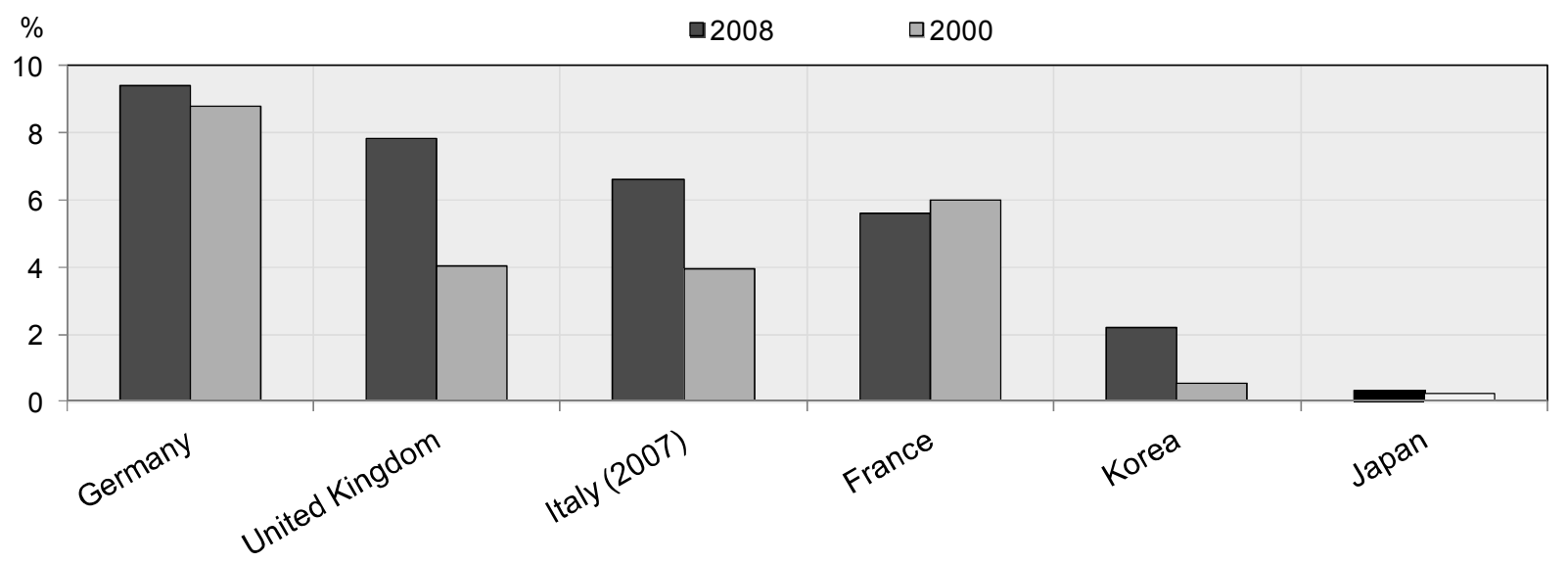

Figure F.3 Nationality diversity index ${ }^{1}$ of G20 OECD countries, based on stocks of foreign population ${ }^{2}, 2008$

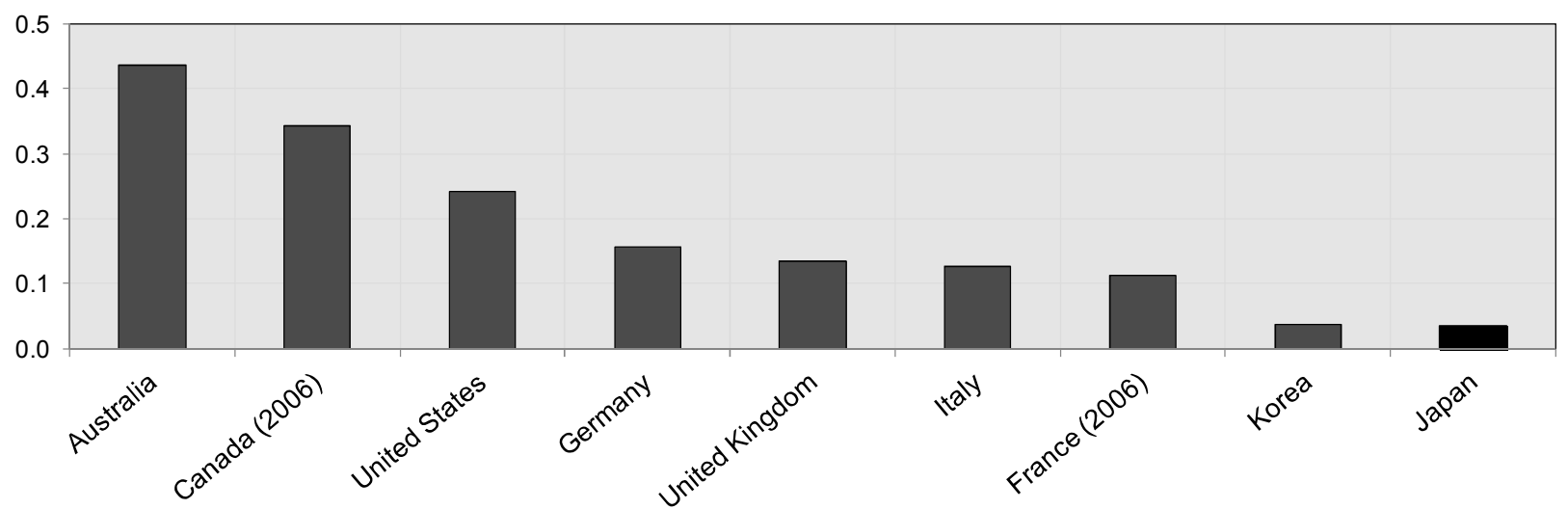

1. This index varies between 0 (no diversity) and calculations include the native population. 2. Stocks of foreign-born population for Australia, Canada and the United States.

Source: OECD Database on Immigrants in OECD Countries - DIOC.

DIOC-E 2000 release 2.0, Barro and Lee (2010) and Lutz et al. (2007) 


\section{G. INTERNATIONALISATION OF HIGHLY SKILLED HUMAN CAPITAL}

International mobility of highly skilled human resources has become a central aspect of globalisation. Migration of talent plays an important role in shaping skilled labour forces throughout the OECD area.

Inbound and outbound flows of highly skilled human capital are quite limited for Japan, suggesting that Japan might benefit less from the so-called brain circulation (Figure G.1). Immigration and emigration rates of tertiary educated people are significantly lower for Japan compared with other countries. Canada, Australia and the United States experience large inflows of highly skilled persons, while these countries also have large numbers of educated people abroad (as do countries like France, United Kingdom, etc.).

Countries also benefit from the inflow of talented students and scholars. Students, especially from developing countries, often move abroad for further research or employment and contribute to innovation in their host countries. About 2.5 million tertiary-level students were enrolled outside their country of citizenship in 2007 in the OECD area. Japan, however, only attracts a small share of these enrolments (Figure G.2).

The international mobility of doctoral students points to the internationalisation of the higher education sector as well as the research system. It often highlights the attractiveness of advanced research programmes and in some cases the existence of career opportunities for junior researchers in the host country. Nevertheless, other factors also play a role including language, proximity, cultural and historical links, the existence of exchange programmes or scholarships as well as migration policies.

The share of foreign doctoral students in total enrolments differs widely across countries: non-citizens represent more than $45 \%$ of the doctoral population in the United Kingdom, but less than $6 \%$ in Italy and Korea. In Japan, the share of foreign and international doctoral students represents almost $17 \%$ of total enrolments (Figure G.3).

\section{Foreign and international doctoral students}

Doctoral students are defined according to the International Classification of Education developed by UNESCO (ISCED 1997). ISCED level 6 corresponds to programmes that lead to an advanced research qualification, equivalent to a doctorate.

The term "international students" refers to students who have crossed borders expressly with the intention to study. The UNESCO Institute for Statistics, OECD and Eurostat define as international students those who are not residents of their country of study or those who received their prior education in another country. Overall, the country of prior education is considered a better criterion for EU countries in order to take account of intra-EU student mobility. The residence criterion is usually a good proxy in countries that require a student visa to enter the country. Since not all countries are yet able to report data on international students, data for "foreign students" are presented here. However, it should be borne in mind that not all "foreign students" have come to the country with the intention to study. 


\section{G. INTERNATIONALISATION OF HIGHLY SKILLED HUMAN CAPITAL}

Figure G.1 Migration Rates of Tertiary Educated, population 15+, circa 2000

Number of tertiary educated emigrants and immigrants as a share of total tertiary educated population

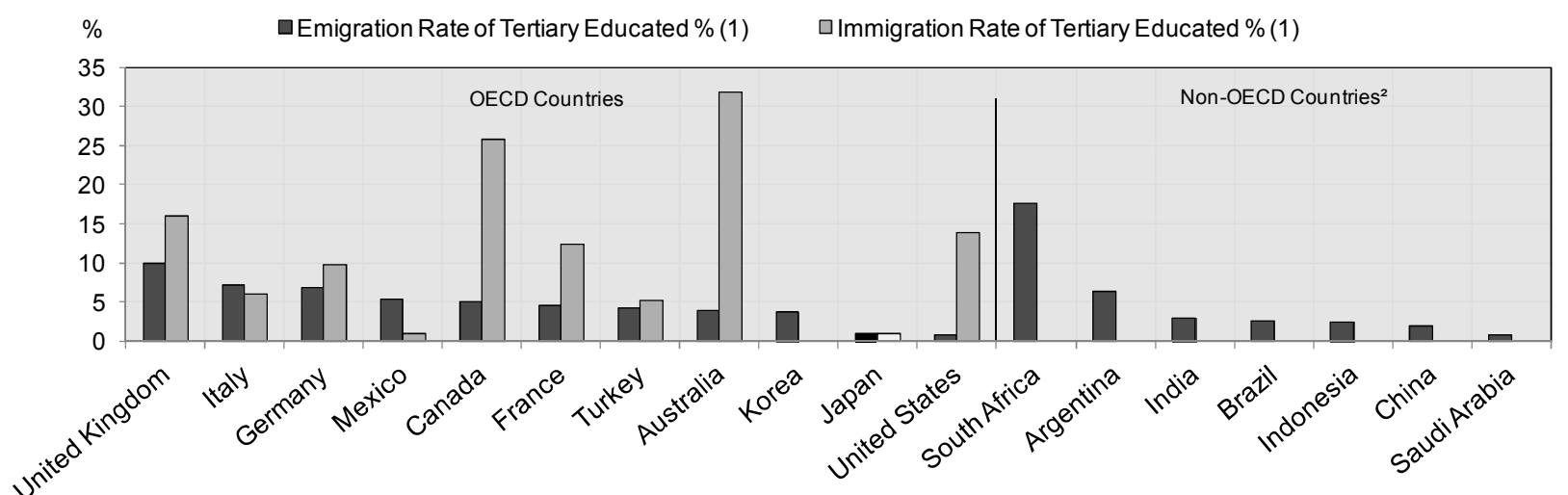

1. Including foreign-born persons in the population of the country of origin. 2. For Non-OECD countries and Korea, immigration rates are not available.

Figure G.2 Student mobility in tertiary education, 2007

Percentage of international students in tertiary enrolments

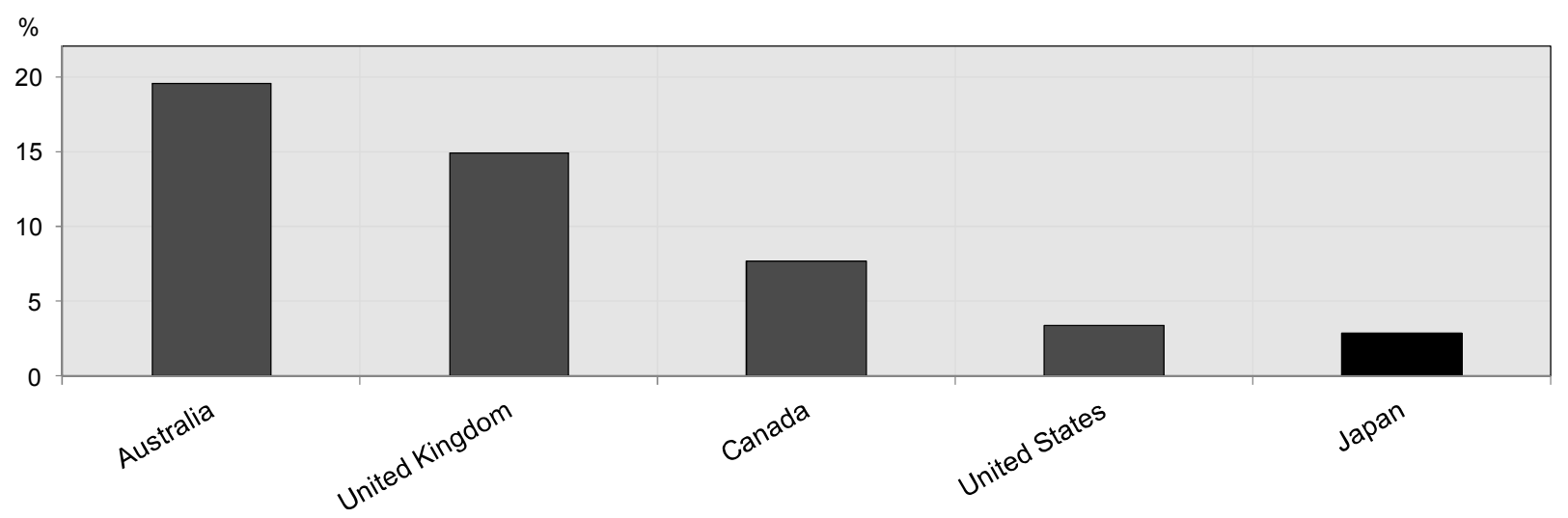

Figure G.3 Share of foreign doctoral students

As a percentage of total doctoral enrolments in host country, 2007

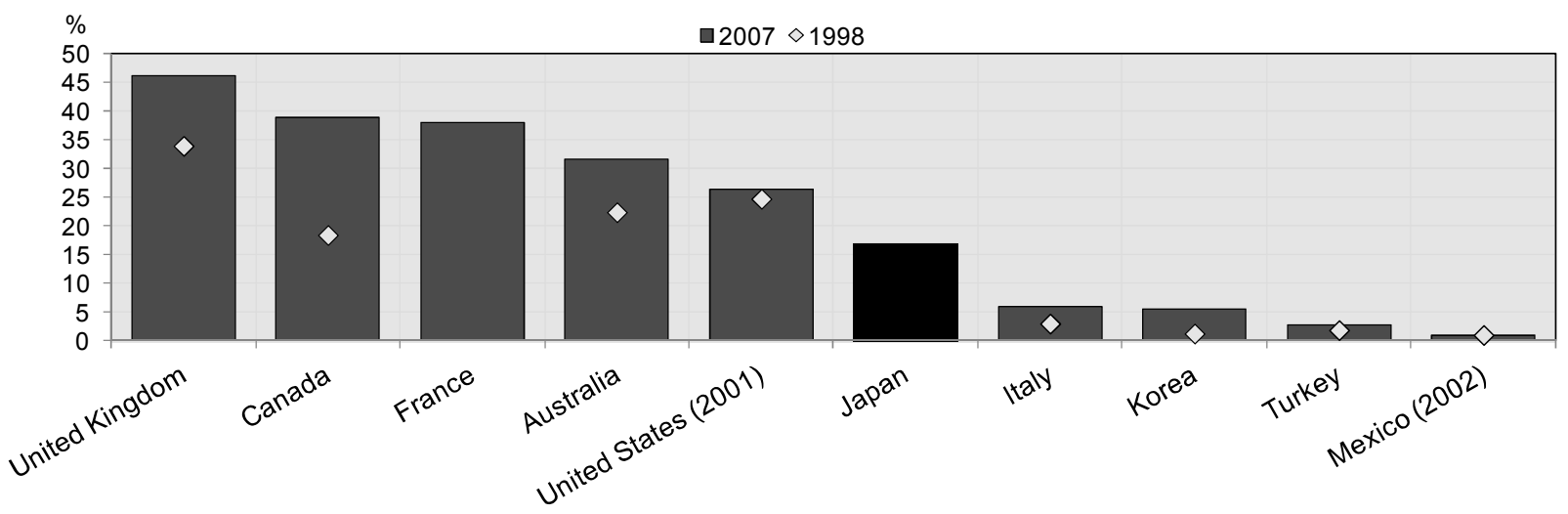

Source: OECD Economic Globalisation Indicators 2010

OECD Database on Immigrants in OECD Countries - DIOC

DIOC-E 2000 release 2.0, Barro and Lee (2010) and Lutz et al. (2007) 


\section{H. CULTURAL DiVERSITY}

Openness transforms economies and societies by developing transnational identities, by forming links between people across the world and by facilitating greater migration. Cultural diversity, defined by the United Nations Educational, Scientific and Cultural Organization (UNESCO) as "the capacity to maintain the dynamic of change in all of us, whether individuals or groups" has an impact on how openness is received and as such directly determines the benefits of openness. Cultural diversity is a broad concept and hence different indicators can be used to measure it across countries. Considerable research is underway to improve the current data and indicators; until now most indicators are based on survey data.

The Diversity Index in the Gallup World Poll Survey measures a community's acceptance of people from different racial, ethnic, and cultural groups. This indicator is based on population survey data that have been collected through standardised questionnaires. Countries scoring high on this indicator are Canada, Australia and the United States, pointing to their status as immigration nations and acceptance for other groups. Japan scores significantly lower on this index.

Another indicator is collected by Institute for Management Development (IMD) in its yearly World Competitiveness Yearbook and is based on survey data from business leaders. Attitudes to globalisation in Japan are perceived to be high; on a scale from 1 to 10, Japan score as high as countries like India, Australia, Korea, Brazil, Canada, etc. The business attitude towards globalisation has furthermore increased in Japan over the past decade.

A third indicator, also coming from IMD's World Competitiveness Yearbook, shows however a lower degree of diversity. The business sector perceives the openness to foreign ideas in Japan as rather low; much lower than in countries like Australia, Brazil, Canada and India. The perception is also that this openness to foreign ideas has decreased since 2000 in Japan; in contrast, this indicator seems to have increased in the majority of the other G-20 countries.

\section{The Gallup Diversity Index}

The score of a country indicates the percentage of individual respondents that agreed with all three questions :

- Is the city or area where you live a good place or not a good place to live for racial and ethnic minorities?

- Is the city or area where you live a good place or not a good place to live for gay or lesbian people?

- Is the city or area where you live a good place or not a good place to live for immigrants from other countries? 


\section{H. CULTURAL DIVERSITY}

Figure H.1 Gallup Diversity Index, 2008

Percentage of respondents answering positive to each of the three questions concerning acceptance of different racial, ethnic, and cultural groups.

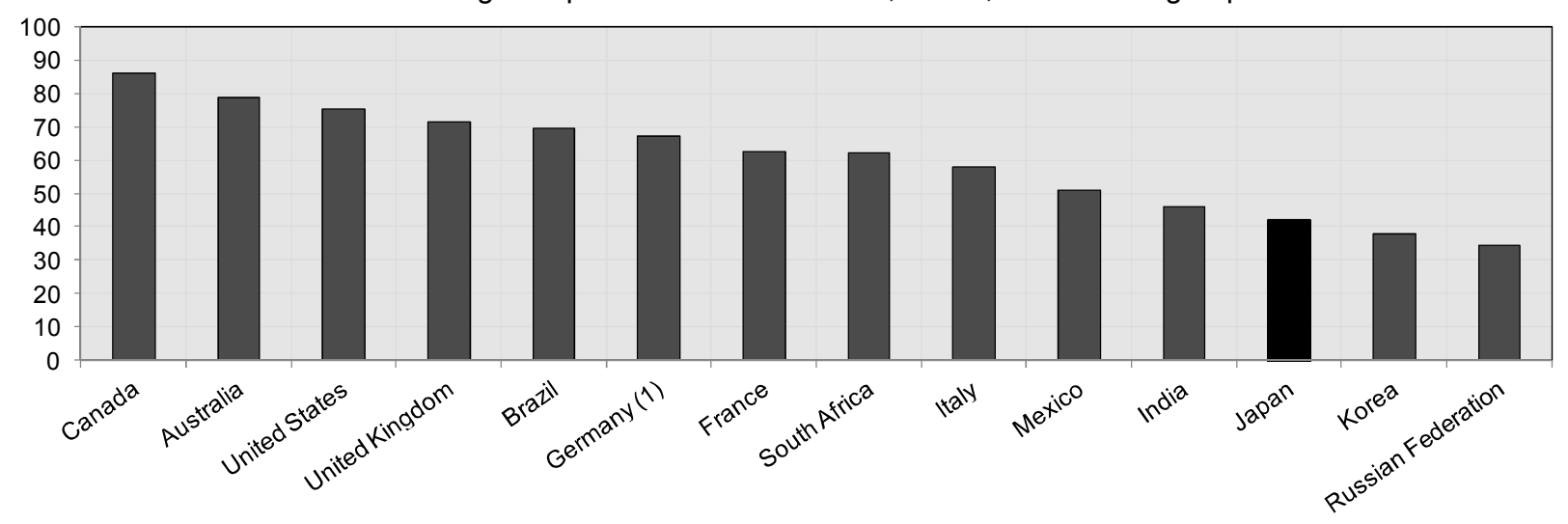

1. Year for this country, 2009.

Figure H.2 Attitudes toward globalisation

Scale from 0 to $10(0=$ no acceptance; $10=$ maximum acceptance $)$

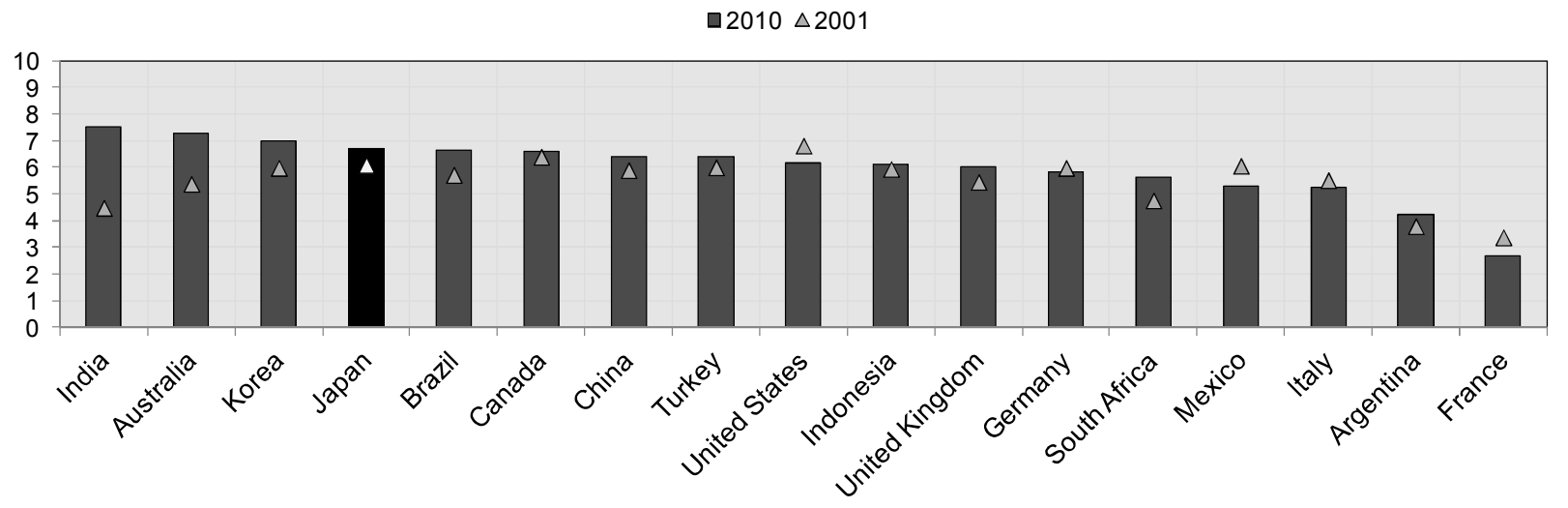

Figure H.3 Openness to foreign ideas

Scale from 0 to 10 ( $0=$ no openness; $10=$ maximum openness $)$

$\square 2010 \triangle 2000$

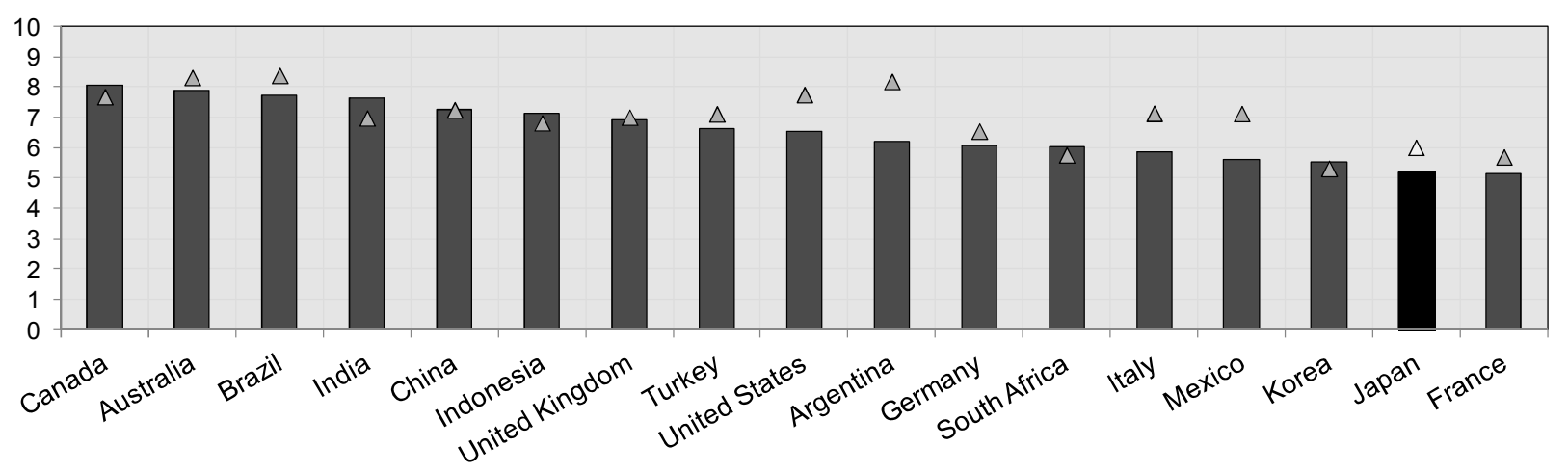

Source: Gallup World Poll, 2008.

IMD World Competitiveness Yearbook, 1995-2011. 


\section{ECONOMIC OPENNESS: SUMMARY}

The radar graph for each country provides a summary picture of the economic openness of that country along different dimensions and is shown relative to the highest scoring G-20 country on each indicator. The higher the index value of the country in question, the more the country will be positioned towards the outside of the graph, the more open that country is according to that indicator. The area obtained when connecting all the index values of a country is a direct proxy for the overall economic openness of a country: the larger that area, the more open the country. At the same time, the radar graph gives insights on which dimension a country is more open or closed.

Overall, the Japanese economy seems to be rather closed especially when compared to the United Kingdom and Germany and to a lesser extent also compared with the United States and Korea. Furthermore, the graphs clearly indicate that Japan is rather closed across all policy domains. The comparison with Korea is particularly interesting, as Korea has a very similar profile to Japan. However, Korea has made significant progress on certain indicators of openness in recent years, including the share of foreigners in the domestic labour force.

When analysing the graphs more in detail along the different dimensions, it becomes clear that Japan is relatively more open on indicators of trade and global value chains. This is probably linked to the process of vertical specialisation that has taken place within Asia. Japan, as a producer of high value intermediate inputs (e.g. parts and components), plays an important role in this process.

Notwithstanding the important role of affiliates of Japanese MNEs abroad, Japan scores relatively low on international investments. The limited inbound flows of capital and investments into Japan are characteristics of the closed nature of the Japanese economy. But Japan is also relatively closed on indicators of the internationalisation of knowledge, certainly compared with the United Kingdom and Germany. The United States and Korea, although having a lower degree of internationalisation of knowledge are still ahead of Japan.

The differences between Japan and the other countries seem to be particularly large on indicators of the internationalisation of the labour market, including the mobility of highly skilled human capital. Both in terms of inbound and outbound flows, Japan shows very low levels of openness, and the difference with the other countries is again particularly marked as regards inward migration. The direct result of this is a lower degree of diversity in the population and the labour force in Japan.

\section{Radar graphs}

To construct the radar graphs, the raw data for each indicator was transformed into an index with the G-20 country with the maximum value of the indicator taking an index value of 100. For example, on the indicator E.1 (Funds from abroad), the United Kingdom showed the highest score $(22 \%)$ and takes the index value of 100 . The index numbers for the other countries are then calculated proportionally; Japan with a value of $2 \%$ received an index value of 9 .

The graphs include the 24 indicators of international trade, international investments, global value chains, internationalisation of knowledge, internationalisation of labour, and internationalisation of highly skilled human capital. Some sub-indicators have been summed up and combined where possible (e.g. immigration and emigration rate, offshoring in manufacturing and services). Given that indicators on cultural diversity are based on survey data, these were not included in the graphs.

For some countries, specific indicators were not available; in order to keep the comparison between countries as optimal as possible, these indicators have been included in the graph but without an index value for the country. The unavailability of specific indicators for individual countries is indicated by the lighter colour of the indicator on the -axis. 


\section{ECONOMIC OPENNESS: SUMMARY}

Figure I.1. Japan

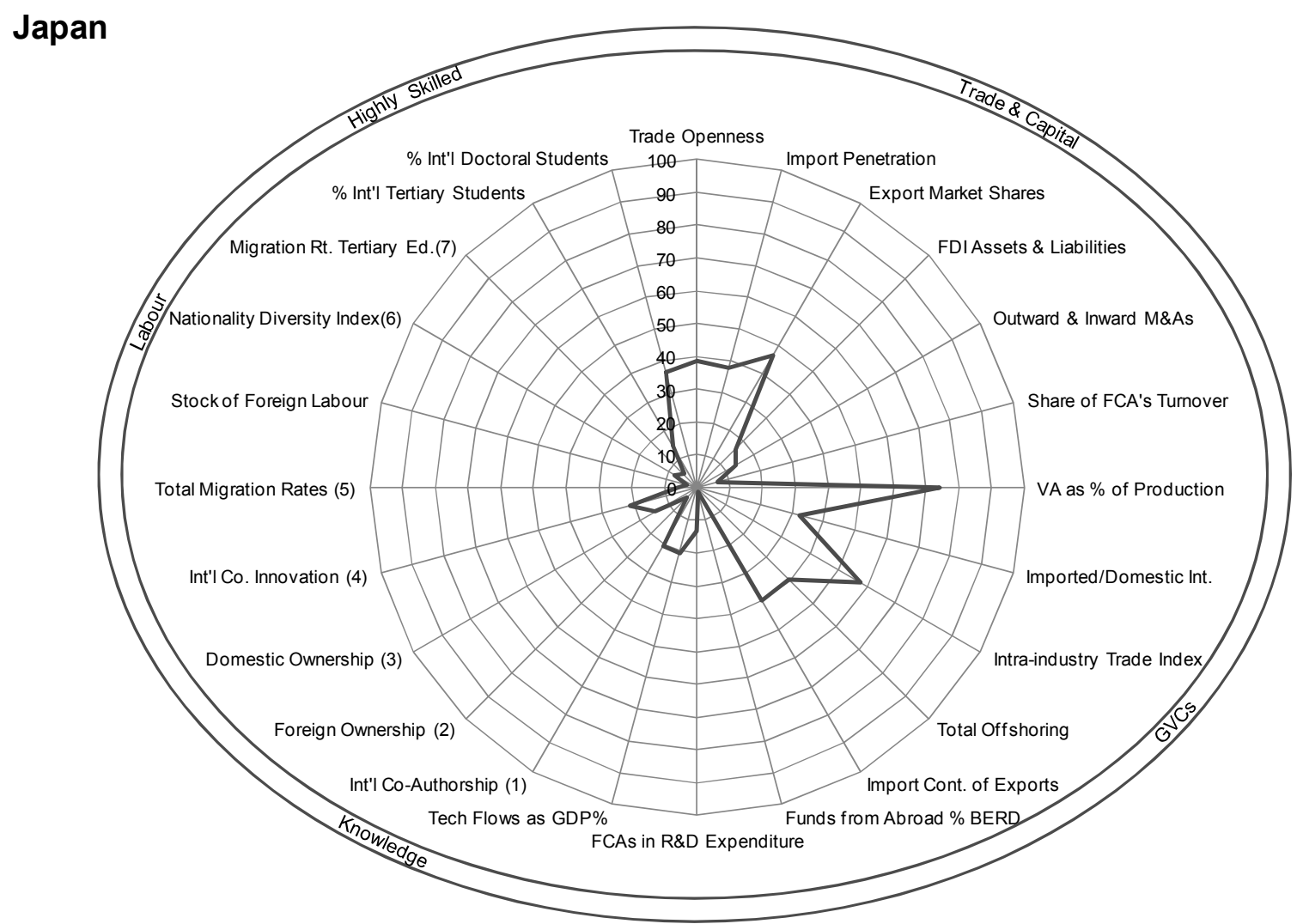

These footnotes refer to all charts:

1. Scientific articles by type of collaboration.

2. Cross border ownership of domestic inventions.

3. Domestic ownership of cross border inventions.

4. Firms with international collaboration on innovation.

5. Including foreign-born persons in the population of the country of origin.

6. Including native-born.

7. Including foreign-born persons in the $15+$ population of the country of origin. 


\section{ECONOMIC OPENNESS: SUMMARY}

Figure I.2 Germany

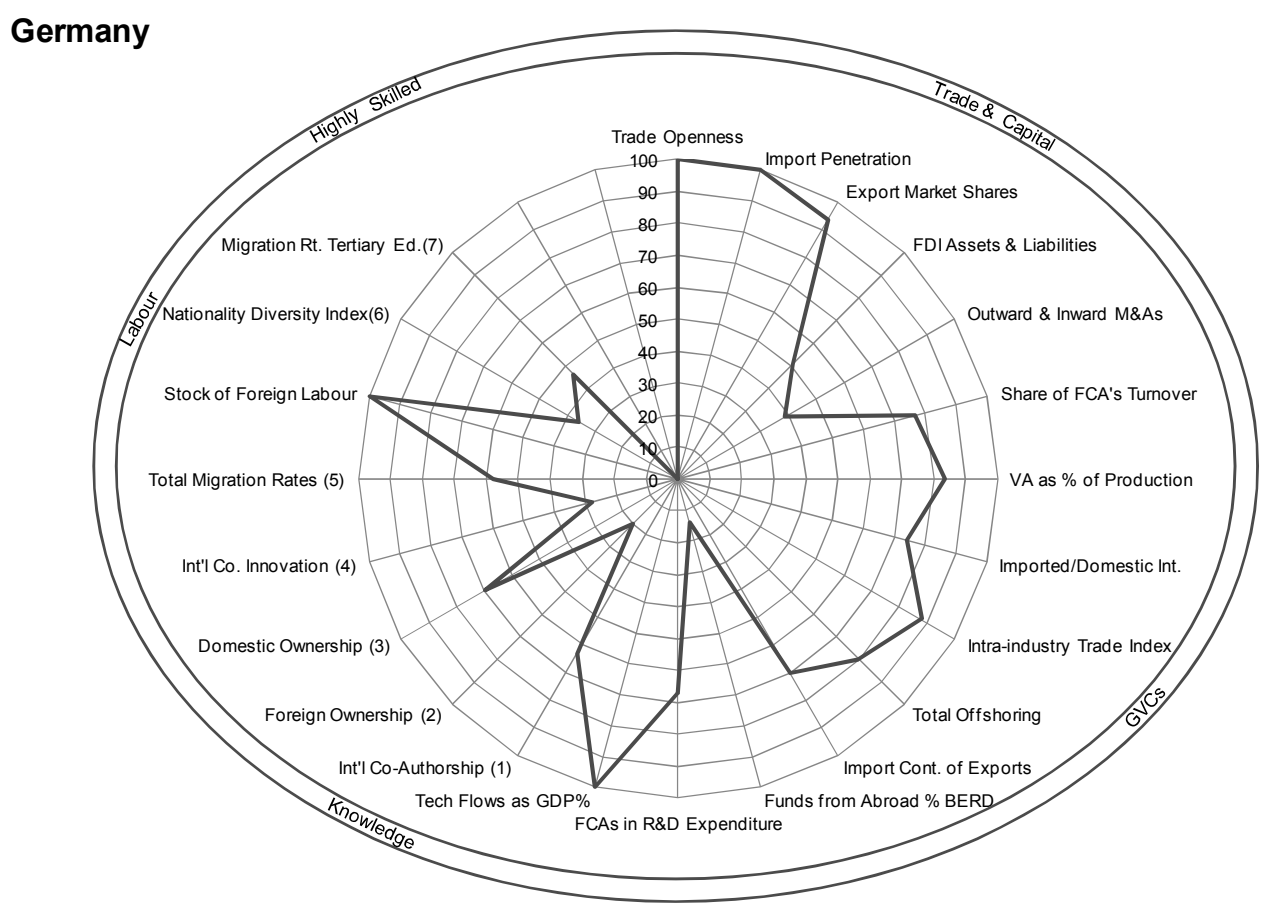

Figure I.3 United Kingdom

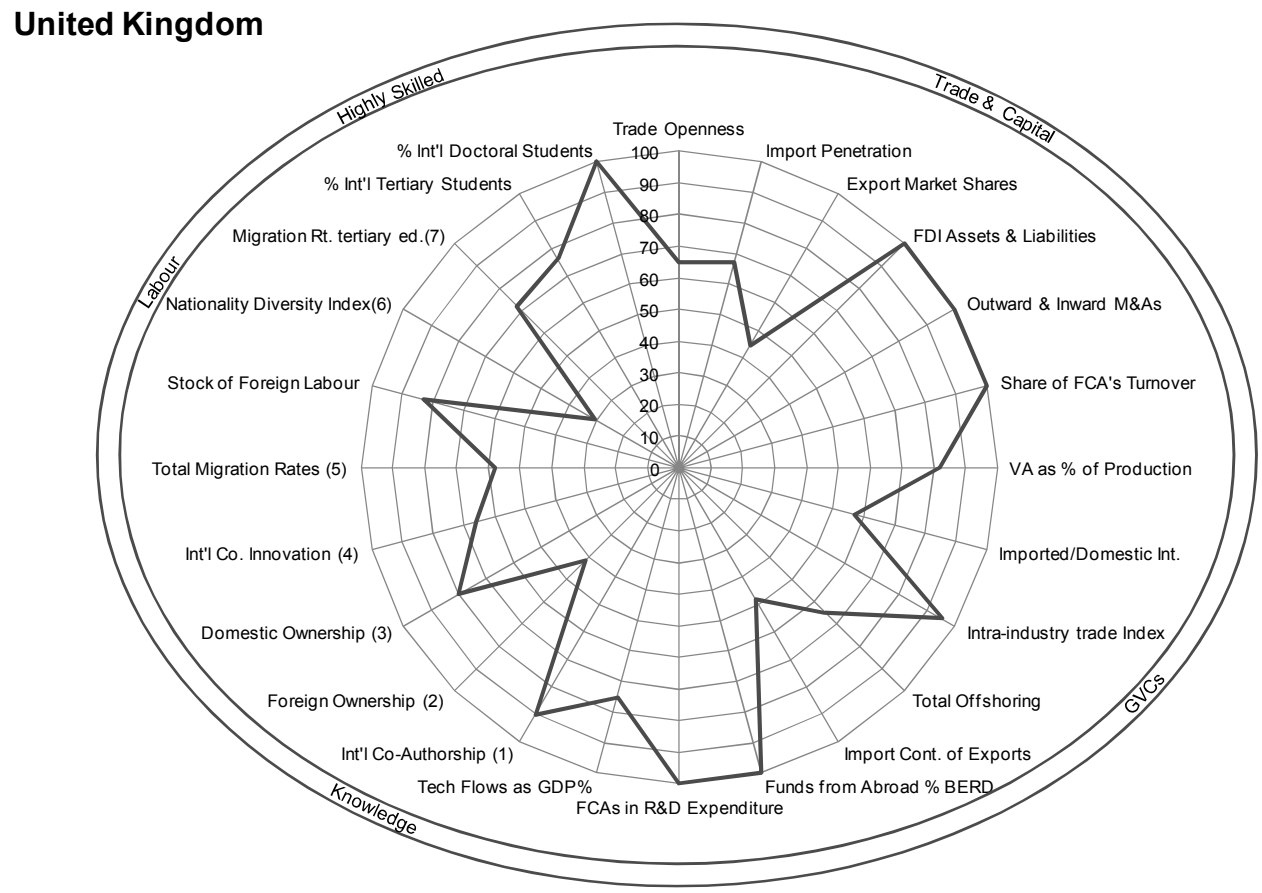




\section{ECONOMIC OPENNESS: SUMMARY}

Figure I.4 United States

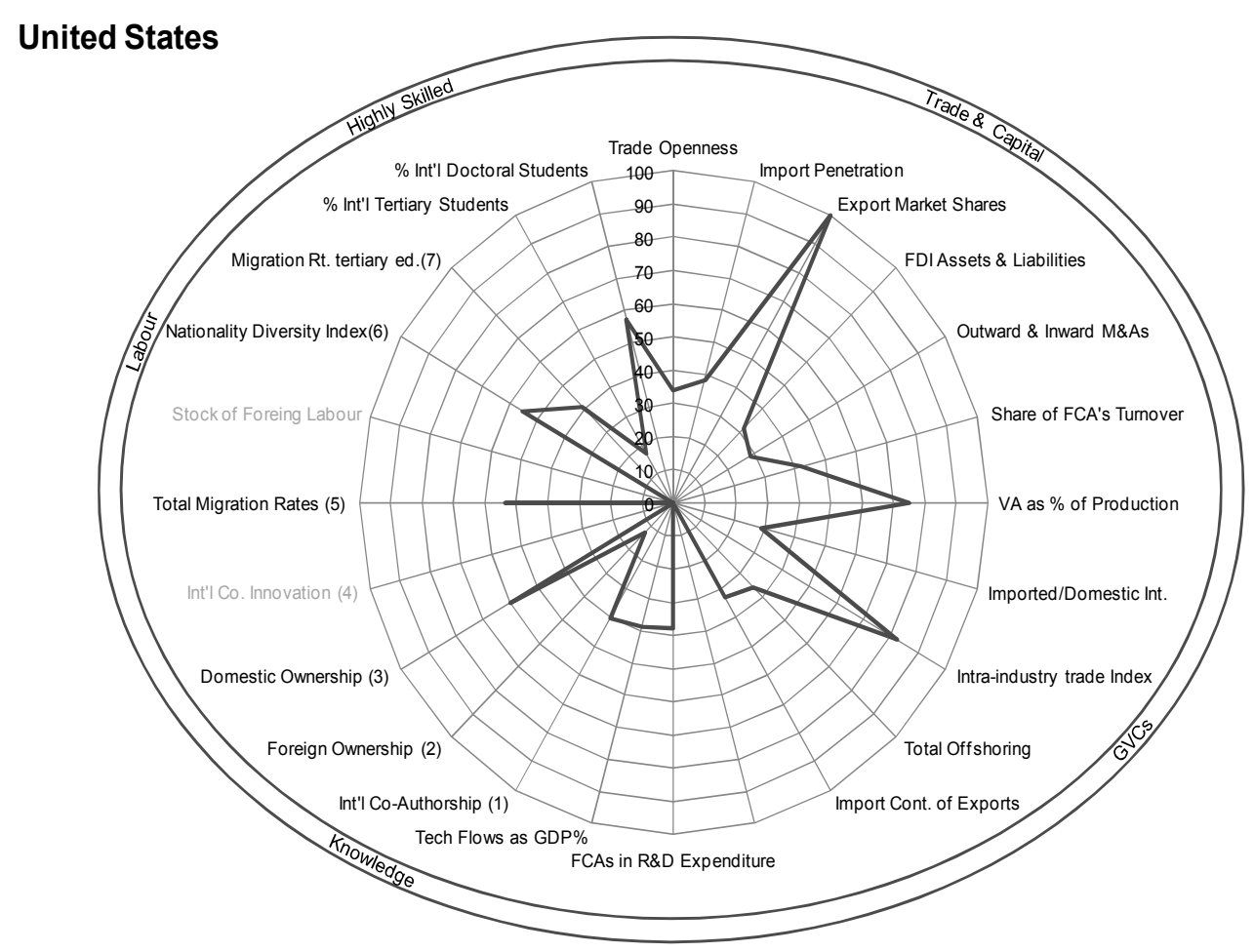

Figure I.5 Korea

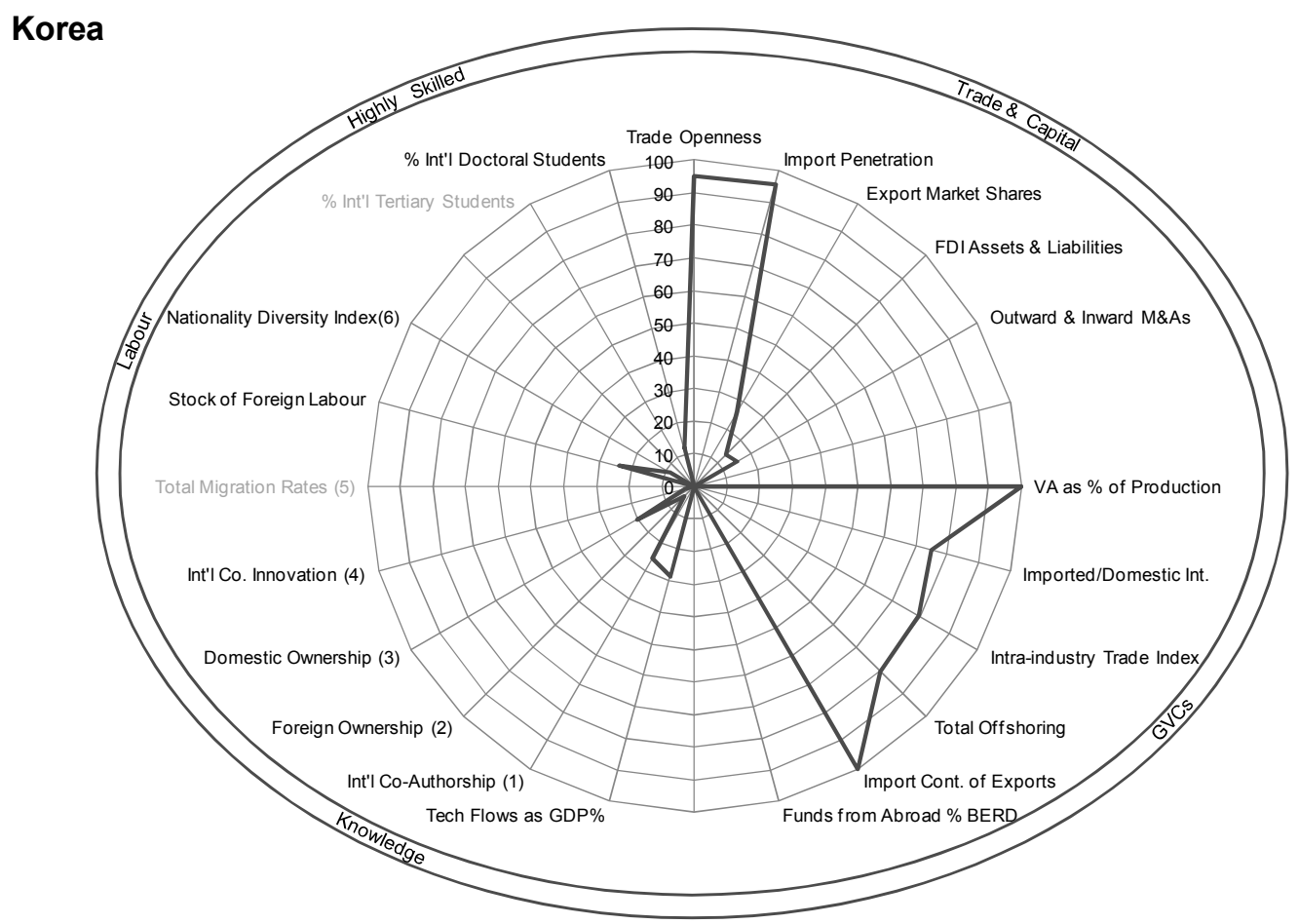


DSTI/DOC(2011)2

\section{CHAPTER 2. OPENNESS AND ECONOMIC GROWTH}

\section{Introduction}

Fostering economic growth is a top priority on the policy agenda of most countries, in particular in the aftermath of the economic crisis. Accelerating economic growth is also of key importance for emerging countries as they want to catch up and close the gap in income levels with developed countries.

Significant differences in growth performance exist between OECD countries. Since the 1990s, growth has decreased in large continental European countries and Japan, while it remained fairly strong in the United States and a number of smaller economies. The consequences of the economic crisis and the strong performance of large emerging economies have resulted in even stronger growing disparities in GDP growth across the world. Due to its consistently high growth rates over the past decade, China overtook Japan as the world's second largest economy in 2010.

Economic growth is driven by a range of factors, including capital accumulation, labour productivity growth, and technology adoption, among others. Openness and integration in the global economy are expected to have a positive impact on the growth performance of national economies. Overall, most analyses conclude that policies promoting economic openness have generated a positive effect on growth.

OECD (2005a) explores the benefits of reforms in product market regulations and increased openness and finds that GDP per capita would increase by between $2 \%$ and $5 \%$ if all external and internal barriers were reduced to the level of best practices for the OECD as a whole. Policy reforms increasing competition would spur the majority of the overall gains in GDP per capita. The lowering of barriers to FDI would generate gains of $0.75 \%$ in GDP per capita in the OECD area, while tariff reductions would lead to a rise of GDP per capita by $0.25 \%$ to $1 \%$. In the case of Japan, this research estimates gains in GDP per capita of $4.4 \%$, with $2.4 \%$ resulting from regulatory reforms, $0.7 \%$ from reductions in FDI restrictions and $1.3 \%$ from tariff cuts.

Increased openness also benefits firms and consumers by exerting a moderating impact on inflation. For example, imports from lower-cost economies can reduce trade prices and lower the mark-ups of domestic producers through increased product market competition. ${ }^{1}$ Econometric analyses of consumer and commodity prices in Pain, Koske and Sollie (2008) show that for most OECD countries globalisation led to a decline in the rate of consumer price inflation of between 0 to $1 / 4$ percentage point per year since 2000 . Although these results may seem small, they probably understate the real effect of openness on inflation, as they do not account for the impact of globalisation on the cost of capital and labour, nor for the impact on inflation expectations.

The concept of openness of an economy has many dimensions. Traditionally, the literature has defined it using several measures of international trade linkages for a country (Belke and Wang, 2005; see Box 1 for more details). However, this traditional definition is somewhat narrow and fails to account for other important aspects that have an important bearing on the connections between an economy and its external dimension. In arguing for the need to quantify the gains from openness rather than the gains from trade, Ramondo and Rodriguez-Clare (2009) hold that "[ $t]$ he notion of openness includes not only trade but all the other ways through which countries interact. Even if a country were to shut down trade, it could still benefit from foreign ideas through the activity of foreign affiliates of multinational firms [...] as well as the flow of ideas through migration, books, journals and the Internet [...]". In quantifying the overall gains from openness through both trade and multinational production, they find average gains from openness of $15 \%$ for OECD country's real incomes. 
Hence, the definition of economic openness adopted in this study refers to the circulation (inward and outward flows) of factors of production, including goods, services, people, capital and knowledge. Such a definition includes international trade but goes beyond it, and encompasses aspects of international investment, migration flows and internationalisation of research and development (R\&D), innovation and knowledge. The following paragraphs will review the theory and evidence on the link between different aspects of openness and economic growth.

\section{Trade openness}

The importance of an open trade regime in promoting economic growth is well founded in the economic literature. The causal link between trade openness and economic growth has been explored extensively both theoretically and empirically. The literature makes an important distinction between static and dynamic gains from trade. The former imply an upward shift of the average productivity level while the latter is defined as trade-related changes in the long-run rate of productivity growth.

In the case of static gains, there are several channels through which the reallocation of resources induced by openness to trade positively affects economic growth (Corcos et al., 2009; Berg and Krueger, 2003; Deardoff, 2001):

- Trade liberalisation allows a country to exploit its comparative advantage to the full extent through deepening specialisation, and therefore reap significant efficiency gains.

- Trade liberalisation may lead to a reduction of production costs thanks to increasing returns to scale, and increases the variety of intermediate and final goods for firms and consumers. It also increases the scope for learning-by-doing externalities. This market size effect is especially important for those developing countries that are too small to be competitive if they produce only for the domestic market.

- Trade liberalisation reduces the distortions of imperfect competition and contributes to achieving a better allocation of resources, as consumers have the possibility of purchasing cheaper and/or better products. Trade-induced product market competition enhances productivity for two reasons: it forces unproductive firms out the market and forces domestic firms to innovate in order outperform foreign competitors.

- Trade liberalisation increases the efficiency of foreign and domestic investment, as firms have access to better capital equipment at lower prices.

- As protection is often associated with rent-seeking activities, trade liberalisation can contribute to curbing the market power of vested interest groups.

- Trade liberalisation can act as a stimulus to governments in implementing complementary reforms.

All the above have an impact on the level of productivity, although in some cases the effect may require a long adjustment period. 


\section{Box 1. Economic openness: definition and measurement issues}

Whitman (1969) defines economic openness "in terms of the relative importance of economic flows across national (or regional) boundaries". This concept is closely associated with, but clearly distinct from, economic integration, which is measured instead "in terms of how closely a group of economies approximates a single, frictionless market, characterised in the limit by the equalisation of all prices". In macroeconomic terms, openness can be measured by looking either at the current account or at the capital and financial account. In addition, openness can be viewed both in terms of integration with the world economy and exposure to the foreign sector. These different angles imply different classifications, as summarised in the table below:

\section{Classification of measures of openness}

\section{Definition of openness}

Current account

Financial account (old capital account)

\section{Measures of integration (policy orientation)}

Trade policy orientation

e.g. tariff levels; incidence of tariffs, price distorsions

Financial account orientation

e.g. exchange rate controls; interest rate parity; savinginvestment correlation

\section{Measures of exposure (significance of foreign sector)}

\author{
Significance of foreign sector \\ e.g. exports and/or imports as a \\ ratio to GDP \\ Significance of financial flows \\ e.g. financial account flows as a \\ ratio to GDP; foreign inflows; \\ foreign activity in stock market
}

Source: Adapted from Hawkins (2003)

In international economics, openness is often associated with trade flows, and a common measure of openness is the average share of exports and imports of goods and services in GDP. However, several different indices can be used and combined, as they capture different aspects of trade openness and each has its own merits and shortcomings. For example, Spilimbergo, Londoño and Székely (1999) use seven different indices of openness, and Edwards (1998) combines nine different measures of openness. Using a computable general equilibrium (CGE) model of the world economy, Lloyd and MacLaren (2002) construct summary measures of openness.

The traditional trade-to-GDP ratio has been criticised for not providing an accurate picture of economic openness. For example, because trade is stated in gross terms while GDP is measured in value added, this index can inflate the actual magnitute of openness. This is also why the index can exceed 100, as is the case for many relatively small and open OECD economies (Belke and Wang, 2005).

In addition, the term "openness" referring to the average trade-to-GDP ratio may be misleading. A low ratio does not necessarily imply high tariff or non-tariff barriers to trade, but may be due to other factors, mainly size and geographic remotedeness from potential trading partners but also a country's history, culture, trade policy, structure of the economy (especially the weight of non-tradable services in GDP), re-exports and the presence of MNEs (intra-industry trade). In 2007 the OECD countries with the lowest ratios were the United States (29\%) and Japan (33\%). Both countries have large economies and they depend relatively less on external markets to satisfy domestic demand (OECD, 2010a). For more details about the degree of trade openness for a selection of OECD and non-OECD countries, see Chapter 1.A.

The shortcomings of the traditional approaches to defining and measuring economic openness call for a more comprehensive perspective that would include a broader range of policies that shape the cross-border economic linkages of a country and the interactions between the external and internal dimensions of its economy. 
In addition to gains affecting the productivity level of an economy (i.e. better resource allocation, deepening specialisation and higher return to investment in capital and R\&D), Nordas, Miroudot and Kowalski (2006) identifies technology spillovers as a channel through which trade may generate dynamic gains, hence having a positive impact on the long-run rate of productivity growth. The direction of knowledge spillovers tends to be from more advanced to less advanced economies, therefore the latter generally benefit the most from these dynamic gains. For example, Coe and Helpman (1995) find that total factor productivity depends not only on domestic R\&D capital, but to a great extent also on foreign R\&D capital. The more open an economy is to foreign trade, the greater the benefits of foreign R\&D will be on domestic productivity.

A large number of empirical studies have analysed these predictions of theoretical models on trade liberalisation and growth. ${ }^{2}$ This literature generally finds a strong positive correlation between trade, income and productivity, but seems to offer less conclusive evidence on the positive and causal link between trade liberalisation and productivity levels or productivity growth. ${ }^{3}$ Besides the problems of defining openness (see Box 1) and the related potential measurement error, empirical cross-country studies struggle overall with determining the direction of causation and isolating the specific effect of trade liberalisation (Winters, 2004; Bassanini and Scarpetta, 2001). The robustness of past studies have sometimes been criticised because of omitted variable bias and endogeneity. Box 2 briefly reviews the issues and possible solutions.

A number of studies have provided evidence that more open countries typically grow faster than less open ones and have higher income levels at any period of time (Edwards, 1998; Harrison, 1996; Sachs and Warner, 1995; Dollar, 1992). The OECD Growth Study (OECD, 2003) estimated a number of growth equations for 21 OECD countries (including Japan) over the period 1971-1998, with the aim of explaining the reasons for differences in growth trends among OECD countries and of identifying policies and institutional settings that may shape long term economic developments. The study finds overall that an increase in openness by 10 percentage points translates over time into an increase of $4 \%$ in per capita income.

More recently, Bouis, Duval and Murtin (2011) extend the sample of countries by including OECD member countries as well as OECD accession and large non-member countries. They find that the key results from previous OECD work are robust to the extension of the sample and largely confim that trade openness has a significant positive impact on long-run GDP per capita levels. ${ }^{4}$ 


\section{Box 2. Econometric issues with cross-country regressions and potential solutions}

Even if one accepts that there is a clear empirical link between trade and growth, the direction of causation could be questioned: does it only flow from openness to increased growth, or is there also an impact of growth on trade? The relative high level of trade openness in OECD countries would reflect patterns of growth as much as active trade liberalisation. Some studies have tried to solve the causality issue by using instruments that would not affect income other than through trade, such as a country's geographical characteristics. In a seminal paper using this methodology, Frankel and Romer (1999) find that an increase in the share of trade in GDP of $1 \%$ raises the income level by between 0.9 and $3 \%$. Therefore, the impacts of trade on income are potentially large (although only moderately statistically significant). There is however a potential issue of model misspecification. In particular, the instrumental variable approach has been criticised from the perspective that geography could in fact affect income through other channels than just trade, for examples via institutions as in Rodrik, Subramanian and Trebbi (2004) and Rodriguez and Rodrik (2001). Examples of other such channels include public health and hence the quality of human capital, quantity and quality of natural endowments, and historical experiences of colonialism, migration and war. Frankel and Rose (2002) address this concern by estimating the impact of trade openness on income with a number of variables that could appropriate some of the effects that would be instead attributed to openness in the absence of those variables. Even with these corrections, the effect of the openness variable on economic growth remains positive and statistically significant.

The economy-wide effects of trade openness on growth have been increasingly supported by recent empirical evidence on the impact of trade liberalisation at the firm level. Aggregate productivity growth is typically the result of the re-allocation of resources to higher-value added activities: to industries that are comparatively more efficient and to more productive firms. ${ }^{5}$ Bernard et al. (2007) show that industries with relatively large falls in trade costs tend to experience larger increases in productivity and offer support for the intra-sectoral reallocation mechanisms and the reduction of X-inefficiencies at the firm level. Stone and Shepherd (2011) discuss similar results for emerging countries, all suggesting an important re-allocation of resources towards more productive firms.

Research has also shown that the type of goods traded matters when assessing the impact of trade openness on productivity. In particular, the literature has singled out the importance of capital goods and intermediate goods. ${ }^{6}$ Imports of those goods may increase domestic productivity more strongly as they embody the transfer of technology, more than imports of final goods which do not impact on the domestic production process (Keller, 2004). Using data of bilateral trade in capital goods ${ }^{7}$, Eaton and Kortum (2001) find that differences in the relative prices of equipment account for over $25 \%$ of productivity differences between developing and developed coutries. They estimate that half of these differences are due to barriers to trade in capital goods, suggesting that removing those barriers could significantly boost productivity.

Miroudot, Lanz and Ragoussis (2009) estimate a production function including a variable reflecting the use of foreign inputs to gross output. They find a positive and significant contribution of the share of imported intermediate inputs to productivity: the more an industry makes use of foreign inputs, the larger the output for a given amount of production factors.

Recent evidence at the micro level shows that imports of intermediate inputs and capital goods can generate significant firm-level innovation and productivity gains, but complementary policies are needed in order to maximise those benefits. For example, Stone and Shepherd (2011) find that a $1 \%$ increase in the share of imported intermediate inputs raises a firm's productivity by $0.3 \%$, and a $1 \%$ increase in capital goods imports raises productivity by $0.2 \%$. These findings suggest that integration into global value chains by opening the economy and lowering trade costs can lead to significant productivity gains.

The majority of empirical studies on the relationship between trade openness and growth use data of trade in goods, or aggregated data of trade in both goods and services. Barriers to trade in services are very seldom included in the definition of trade openness. However, the question of the effect of openness to 
foreign services on income also deserves some attention. Openess to foreign services yields distinctive benefits. $^{8}$ In particular, attention has focussed on the productivity and growth in services sectors that provide essential inputs to other sectors of the economy.

Li, Greenaway and Hine (2003) showed that in developed countries, openness to trade specifically in services has a positive and significant effect on growth. ${ }^{9}$ Disaggragating services into three categories, the authors find that transport and tourism tend to have a negative effect on growth, but the variable capturing the effect of other services (including business services) is positive and statistically significant. This finding seems to confirm the hypothesis that imports of business services may contribute to transfer knowledge and know-how and therefore impact positively on growth via this diffusion.

Researchers have focussed in particular on two sectors to find evidence of the impact of openness to foreign services on economic growth: financial services and telecommunications (Nordas, Miroudot and Kowalski, 2006). For instance, Mattoo, Rathindran and Subramanian (2001) perform a cross-country regression of economic growth on openness to trade in those two services sectors and a number of standard growth controls. For both sectors they find that liberalisation significantly contribute to explaining economic growth and, more specifically, countries with open telecommunications and financial services sectors may experience growth rates that are on average 1.5 percentage points higher than in other countries.

In order to ensure that the economy reaps the full benefits stemming from openness, trade policy should be complemented by other measures. Stone and Shepherd (2011) discusses the relevance of complementary policies in order to optimise the gains from trade: competition policy, lowering the entry barriers for new firms, building human capital and improving access to skilled labor, improving access to factor markets, improving the macro-economic environment and reducing policy certainty.

\section{Openness to foreign direct investment}

The beneficial impacts of foreign direct investment (FDI) on economic growth are also widely recognised and relate to the expansion of productive capacity, job creation, human capital enhancement, innovation and technology diffusion, and enterprise development, all of which contribute to increases in overall income. Local capabilities are typically enhanced if FDI leads to the introduction of efficient organisational practices, machinery, and technologies. Several studies have also documented the superior performance (e.g. in productivity, innovation, $\mathrm{R} \& \mathrm{D}$, etc.) of foreign affiliates relative to domestic firms in host countries (OECD, 2011a).

Furthermore, because of the existence of externalities, (unintended) benefits might spill over from MNEs to the local economy. When these spillovers are assimilated by local suppliers and customers, the local workforce, and local firms, FDI will additionally contribute to productivity growth for the host economy (Caves, 1996). Overall, the scope for spillovers to the host economy depends on the technological strength of the parent firm, the extent to which technologies are transferred to the affiliate, and the extent of integration of the foreign firm into the host economy (OECD, 2007).

However, FDI does not generate positive externalities on the host economy automatically, and complementary policies are needed in order to ensure that those benefits do materialise. One condition for substantial spillovers is a sufficient 'absorptive capacity' of the local economy, e.g. the sophistication of local suppliers, the skill level of the workforce, and the technological sophistication of host country firms in the industry of the affiliate (Görg and Greenaway, 2004; Cohen and Levinthal, 1990). In addition, the size of spillovers is directly dependent on the degree of interaction of foreign affiliates with the local workforce, local suppliers, customers, government institutions, industry associations, educational institutions and research centres. 


\section{DSTI/DOC(2011)2}

Several studies have explored the empirical link between FDI and output growth, and support the view that FDI has a beneficial impact on the local economy ${ }^{10}$. For example, de Mello (1999) finds a positive and statistically significant effect of FDI on output growth, on a panel of 16 OECD countries and 17 (mostly Asian) non-OECD countries. ${ }^{11}$ A number of studies however found no or even a negative effect of foreign investment on productivity and growth of the local economy. A lack of absorptive capacity (broadly defined) seems to explain negative effects of FDI such as crowding out of domestic investment, external vulnerability and dependence, destructive competition of foreign affiliates and "market-stealing effect" (Wan, 2010). Alfaro et al. (2010) find that increases in the share of FDI or the relative productivity of foreign firms leads to higher additional growth in financially developed economies compared to those observed in financially under-developed economies. In addition, they also find support for the fundamental role of human capital to maximise the benefits from FDI. These results may explain why empirical studies based on micro data found no effect of foreign presence or negative productivity spillovers from MNEs in developing countries.

FDI seem to impact growth differently depending on the sector to which foreign investment flows. Alfaro (2003) finds that FDI inflows into the primary sector have a negative effect on growth, while foreign investment in the manufacturing sector has positive effects. ${ }^{12}$

In regard to FDI, policy makers often make a distinction between "good" foreign capital brought in the country via greenfield investment and "bad" investment represented by mergers \& acquisitions (M\&As) and other forms of foreign takeovers. However, this differentiation appears to have little support (OECD, 2008a). Some of the perceived negative effects of M\&As include:

- Threats to national security. This is particularly the case if the foreign takeover targets the defence industry, but also for industries that are deemed strategic for the country's international competitiveness.

- Loss of technological capabilities. This may be particularly disruptive if the technology in question is a key determinant of the local economy's comparative advantage. The majority of $\mathrm{R} \& \mathrm{D}$ activities of MNEs are still concentrated close to corporate headquarters. This seems to suggest that R\&D activities carried out in the country where the target acquisition is located might be affected following corporate restructuring and rationalisation of activities. However, FDI does not necessarily lead to a loss of technological capabilities. An MNE may decide to keep R\&D activities in the host country in order to be close to the "lead users" of the local market (OECD, 2011a).

- Negative impact on local employment. Because M\&As are often driven by considerations of economic efficiency and rationalisation, they may be followed by massive layoffs or even altogether closures of some plants, causing significant job losses.

While the overall evidence is rather mixed, empirical studies tend to suggest that the main benefits of FDI (such as productivity gains) do not depend of the mode of entry (OECD, 2008a). The beneficial effects of FDI inflows on the growth of the receiving economy highlighted above are of similar importance in the case of both greenfield investment and M\&As. At the micro level, most empirical studies conclude that cross-border M\&As have a positive impact on the target firm, in terms of productivity, operational efficiency and international competitiveness. Wages are also found to be increasing following a crossborder M\&A. Overall, cross-border M\&As are likely the have a net positive welfare effect. However, recent research shows that the benefical effects might be dependent on the origin of the acquiring firm (Chen, 2011). 


\section{Internationalisation of $R \& D$}

The beneficial impacts of inflows of FDI, in particular knowledge spillovers from MNEs, are closely related to the internationalisation of R\&D. As intangible assets are transferred through FDI and augmented through local R\&D, this can generate important positive welfare effects for host economies. OECD (2008b) points to a more efficient innovation process, better ability to learn about R\&D conducted by other companies and institutions, a quicker road to commercialisation, and a positive impact on the firm's own innovation capacity.

Host countries might benefit from inward R\&D as this will directly impact the competitiveness and productivity of foreign affiliates. This might in turn result in greater export capabilities and more expanded roles of these foreign affiliates in the multinational network of affiliates. Second, local R\&D provides training and employment opportunities to host country scientists and engineers and increases innovative capabilities of the host country, which may attract further investments by foreign investors. Third, R\&D activities provide spillovers to local firms, through demonstration effects, mobility of R\&D personnel, embeddedness in local networks involving universities and local firms, and interactions with suppliers and customers (OECD, 2008b).

Externalities in the form of disembodied knowledge spillovers to local firms depend crucially on the absorptive capacity in host countries and a technology gap between MNE and host countries that is not too large. The benefits of inward R\&D investments to host economies are more likely to arise if the host country actors have a sufficient level of technological development to learn from and absorb the technologies developed and exploited by the foreign MNEs, hence the need again for complementary policies (OECD, 2008b). In order to maximise the spillover effects, countries that receive investment in $R \& D$ activities could strengthen agglomeration effects in domestic clusters and increase local absorptive capacity.

The need for complementary policies is further stressed since inflows of R\&D activities from abroad may also generate less positive effects. These include loss of control over domestic innovative capacity, with potential impacts on the technological competitiveness of domestic firms. They could also lead to a crowding-out effect in local R\&D and the local labour market. And if the host country does not have sufficient capacity to appropriate the results of the foreign R\&D activities and/or the spillovers therefrom, it will lose economic benefit that will be exploited elsewhere (OECD, 2008b).

There are only a few empirical studies analysing the impact of inward R\&D investments on host countries; the limited evidence seems to indicate that R\&D-active MNEs are indeed more intensively embedded in host economies (relative to non-active R\&D MNE affiliates), providing the conditions for local spillovers. In contrast, several studies have analysed the effect of international $R \& D$ on the performance of the host economy, thereby focusing on the role of FDI as a channel for knowledge spillovers:

- Studies focusing on national-level spillovers: R\&D spillovers through international trade (as in Coe and Helpman, 1995), through FDI (as in van Pottelsberghe de la Potterie and Lichtenberg, 2001) and through international patenting (as in Eaton and Kortum, 1996);

- Studies focusing on firm-level (or establishment-level) spillovers related to FDI and patents (Branstetter, 2006; Peri and Urban, 2006; Hu, 2004; Veugelers and Cassiman, 2004; Braconier, Ekholm and Midelfart Knarvik, 2001).

Overall, these studies point to the key role played by the internationalisation of R\&D and foreign affiliates in enhancing total factor productivity. For example, using micro data from the Survey of Japanese 
Business Structure and Activities prepared by the METI, Kiyota (2006) analyses the effects of local and international R\&D spillovers on productivity growth at the firm level. He finds that the effects of international $R \& D$ spillovers through foreign ownership are positive and significant. In addition, purchases of foreign patents also have a positive and significant impact on productivity growth.

The phenomenon of internationalisation of business R\&D is closely related to the broader trend of open innovation. As company's innovation activities are becoming international, they are increasingly embracing open innovation, i.e. collaborating with external partners, whether suppliers, customers or universities, to keep ahead of the game and get new products or services to market before their competitors (OECD, 2008c). The most important benefit of open innovation to companies is that it provides a larger base of ideas and technologies, while it allows to explore new growth opportunities at a lower risk. Open technology sourcing offers companies higher flexibility and responsiveness without necessarily incurring huge costs. MNEs' innovation eco-systems or networks often represent the nodes between regional or national systems of innovation across borders, and thus link various actors in the science and technology field across different countries.

\section{Mobility of highly skilled workers}

Another important aspect of openness refers to the mobility of highly skilled workers, in particular of human resources in science and technology (HRST). The inflow of talented individuals from abroad may prove to be necessary to achieve and sustain high rates of productivity and output growth in the OECD knowledge economies; the more since a number of OECD countries are expected to face severe skill shortages in the coming years.

Forecasts of the World Economic Forum (2010) indicate that OECD countries like Germany, Italy and Japan will be the most affected, with their economically active population shrinking between $0.7 \%$ to $1.3 \%$ annually between 2020 and 2030. In particular, the study singles out Japan as an economy that will face acute skill shortages in many industries. The report suggests that in addition to investing in the education and training of the domestic supply of skills, OECD countries should also attract highly skilled migrants by designing appropriate migration policies.

Existing research has largely focused on the analysis of specific categories of highly skilled migrants (e.g., HRST) and finds evidence of the benefits of foreign HRST for receiving countries (OECD, 2008d; Guellec and Cervantes, 2001). For instance, Stephan and Levin (2001) find that a disproportionate number of foreign-born and foreign-educated individuals made exceptional contributions to science and engineering in the United States. They conclude that the United States has benefitted greatly from immigration of foreign-born talent and from investment in higher education in foreign countries. Recent results using US data from the National Survey of College Graduates (NSCG) suggest that skilled immigrants have a positive effect on the host country's total factor productivity and per capita GDP growth (Hunt, 2010).

An open migration regime may also lead to increased inflows of migrant entrepreneurs. (OECD, 2010d) reviews some of the positive impacts of migrant entrepreneurship on the host economy. For example, a foreign-born SME owner creates on average between 1.4 and 2.1 additional jobs in the host economy. Hunt (2010) shows that in the United States college-educated immigrants outperform collegeeducated natives in activities that are likely to increase total factor productivity, including the creation of successful companies. In addition, several studies find that migrant entrepreneurs have a positive impact on trade between home and host country. Estimated effects vary considerably, and range between $0.1 \%$ and $3.5 \%$ of increased trade due to a $10 \%$ increase in total migrant stock in the host country (Hatzigeorgiou, 2010). 
Conventional wisdom holds that the transfer of highly educated people from one country to another (commonly referred to as "brain drain") will lead to a loss of productive and innovative capacity of the sending country. More recently, "brain circulation" has attracted policy attention since the temporary and circulation migration between home and abroad and may be beneficial to the sending countries. Individuals may transfer the knowledge they acquire to their home country and maintain networks abroad; they often return to the home country after a period abroad and will likewise transfer knowledge. In order to maximise the benefits from brain circulation, countries need to implement policies that ensure sufficient absorptive capacity. In particular, returning highly skilled professionals should be able to integrate in the local labour market at a level that is appropriate for their skills and knowledge (OECD, 2008d).

\section{Outward openness}

Benefits accruing to the sending country are not only limited to human capital (of highly skilled), but may also arise from other factors of production (capital, R\&D, labour, etc.). The removal of barriers to outward flows (for goods and services, capital, $\mathrm{R} \& \mathrm{D}$, etc.) therefore may directly benefit local firms and consumers. Nevertheless, following the increasing globalisation there is considerale debate in countries that investment abroad might displace domestic investment and employment.

The internationalisation of production and the emergence of global value chains (GVCs) have raised fears about the offshoring of activities and jobs to foreign countries, especially those that enjoy lower production costs. However, most of the vast literature that has explored this issue concluded that the overall impact of internationalisation of production on the domestic labour market is relatively small and often has a termporary character; nevertheless significant differences may arise across occupations and skills groups (Molnar, Pain and Taglioni, 2008). Furthermore, offshoring of activities and investment abroad benefits the home country in terms of productivity, innovation and competitiveness. Firms that offshore (labour-intensive) jobs to low-cost countries may end up saving domestic jobs since offshoring strengthens their international competitiveness. The tasks that are moved offshore increase the productivity of the activities that were not relocated (Grossman and Rossi-Hansberg, 2008; Grossman and RossiHansberg, 2006).

Focusing specifically on MNEs, empirical studies have found evidence that there is a strong and positive correlation between the domestic and foreign activity level of MNEs. Herzer (2010) evaluates the impact of outward FDI on economic growth in the home country for the United States and reports a robust positive relationship between outward FDI and growth, including for outward investment flows towards lower cost countries. Kokko (2006) surveyed the literature on the impacts of outward FDI on the home economy of developed countries' MNEs through the following channels:

- Exports: most studies find a positive, albeit small, effect of outward FDI on home country exports. Exports of final goods are often replaced by exports of intermediate goods (from the home country headquarters to affiliates abroad), suggesting that MNEs'exports from home and host countries are complements rather than substitutes.

- Employment: earlier studies focusing on employment instead of trade seem to suggest that increases in affiliate employment tend to reduce parent employment. However, this seems to be explained by a contemporaneous shift in labour demand from "blue-collar" workers to "whitecollar" employees, which would reflect the fact that MNEs export production activities while concentrating management and R\&D at home. But research on Swedish and Japanese MNEs have cast doubt on these shifts in employments. And more recently, Desai, Foley and Hines (2009) reported that a $10 \%$ increase in foreign investment is associated with a $2.6 \%$ increase in domestic investment in the United States. The effect of foreign operations on domestic 
employments seems to be dependent on a number of factors, such as the type of activities offshored, the industrial structure, the competitiveness of home and host country, etc.

- Investment: the evidence is rather mixed, with some studies reporting crowding out effects between domestic and foreign investments, while others finding no evidence of substitution between investment at home and abroad. A number of other studies even show positive effects of foreign investment on domestic investment because of the positive impact on firm profitability.

- Knowledge spillovers: outward investment seem to generate a positive impact on the home economy because of reverse spillovers, especially in so-called "asset-seeking" or "home-base augmenting" FDI, i.e. technology sourcing investments. New discoveries arising from the global innovation network might thus directly benefit the home country. Using references in Swedish patent data, Globerman, Kokko and Sjöholm (2000) find that outward FDI is a channel for diffusion of foreign technology to both home country MNEs and SMEs. The results for Italian MNEs in Falzoni and Grasseni (2005) suggest a positive effect on firm productivity from their outward foreign investments in developed countries.

Obashi et al. (2010) recently investigated the effects of outward FDI on firm behaviour and performance (in terms of employment, wages and total factor productivity) in Japan. The analysis is carried out over two dimensions: $i$ ) differences between horizontal FDI and vertical FDI, ${ }^{13}$ and ii) differences between firms conducting production activities and firms performing non-production activities.

They find that horizontal FDI barely affects the firm's performance at home; TFP, wages and the number of production workers do not change significantly while the overall (production and nonproduction) number of workers does increase in the long run. As to vertical FDI, wages in production firms are observed to increase reflecting the growing specialisation in skilled labour-intensive activities. However, the employment level in production activities does not vary in the long run, nor does TFP (except for an increase in production activities in the short run). These results dispel the conventional wisdom holding that outward FDI will inevitably lead to job losses; instead they show that openness to outbound investment flows may generate gains in the wages of educated and trained workers.

A survey of the business perception on the benefits of R\&D offshoring among $158 \mathrm{EU}$ companies revealed that two thirds of the respondents considered that R\&D offshoring had improved the cost efficiency of product innovation processes. More than $60 \%$ of respondents believed that R\&D offshoring had improved their companies' ability to learn about R\&D conducted by other firms and institutions. The main benefits cited by respondents included: cost savings; access to skilled labours; strategic alliances and networks with other companies, institutions, competitiors or competitors; market proximity; possibilities to acquire new technologies (Ltt Tutkimus Oy, 2007). These results suggest that outward internationalisation of R\&D activities may contribute significantly to companies' operational efficiency, productivity and growth.

\section{Conclusion: Openness can generate sizeable benefits for the local economy}

This section has provided a brief overview of openness-induced economic impacts on the local economy. Although several methodological and data constraints rarely allow performing a fully-fledged cost-benefit analysis, a convincing amount of evidence shows that openness generates a net positive welfare effect. From a review of the vast theoretical and empirical literature, it can be concluded that economies overall benefit from increased openness although some costs are incurred especially to those sectors, activities and categories of individuals that benefit the most from protection. This suggests that governments need to complement their policies to foster openness with structural adjustment policies, to enable reallocation of resources to other sectors of the economy. 
A second important conclusion from this review is that openness should preferably be interpreted rather broadly, reflecting the broad character of current globalisation. On top of the traditional channels of trade (goods and services) and FDI (capital), globalisation increasingly includes the circulation of people (including the highly skilled), R\&D, technology and knowledge. In addition, economies not only benefit from inbound flows but also significantly from outbound flows due to spill over and positive effects returning to the host economy. Effective policies on openness relate then not only to opening the domestic economy to economic actors from abroad, but also promoting and stimulating domestic firms to deploy international activities.

The third important observation is that the economic benefits of openness do not occur automatically. There is a need for complementary policies to ensure that firms and workers adjust to the growing openness of the domestic economy and consequently that aggregate benefits for the host economy are optimised. 


\section{CHAPTER 3. POLICIES SUPPORTING OPENNESS}

\section{Introduction}

As noted throughout this report, economic openness does not necessarily yield automatic benefits, and complementary government policies may be needed to ensure that the national economy draws benefits from greater openness. Governments may wish to pay particular attention to three issues: $i$ ) designing and implementing policies to open the economy; ii) complementing openness with policies that help the economy adjust to liberalisation; and iii) engaging in policies that ensure that the economic benefits stemming from openness are optimised.

This section describes some of the policies that governments can use to increase the degree of openness of the economy and reap its subsequent economic benefits. It illustrates how countries have implemented specific policies towards openness in presenting some case studies from selected OECD countries. These case studies show how policies promoting openness can be instrumental in generating domestic and foreign investment and innovation. ${ }^{14}$

\section{Promoting trade and investment liberalisation}

Trade and investment liberalisation is at the heart of policies to enhance and maintain openness, as a very large share of all exchanges between economies occurs through trade and investment. Figure 1 presents the "Barriers to Trade and Investment" domain from the 2008 OECD Product Market Regulation (PMR) indicators, including all OECD countries that are also members of the G20 as well as three other G20 countries for which data were available (China, India and the Russia Federation). Overall, this indicator shows that barriers to trade and investment are low in Japan relative to other G20 countries. However, specific trade and investment-related components of this composite index vary quite significantly, and are explored below.

Two case studies on the gains of trade and investment liberalisation and regional economic integration are presented at the end of this sub-section (Box 3 and 4). 
Figure 1. OECD product market regulations: Barriers to trade and investment, 2008

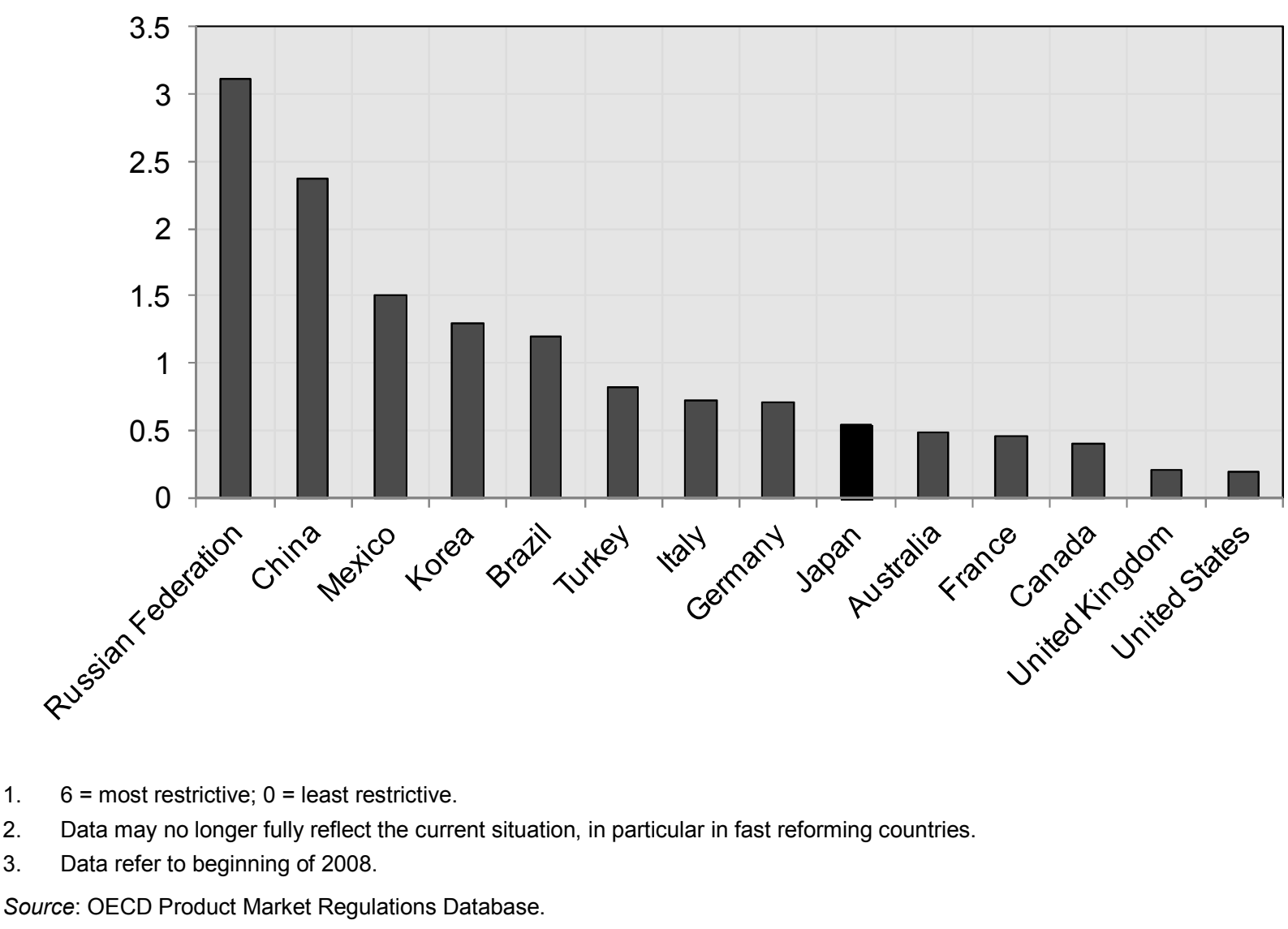

\section{Trade policy}

Trade liberalisation is fundamental to ensuring openness of an economy. Although the concepts of trade openness and trade liberalisation are closely related, they are also different. While trade openness is a measure of performance, trade liberalisation is policy-driven, and can thus be directly influenced by governments. Trade openness can be seen as a potential outcome of active trade liberalisation. In addition, this distinction allows separating the impacts of trade from the impacts of trade liberalisation. As noted by Nordas, Miroudot and Kowalski (2006), some countries are "naturally" open because of location and endowments of resources. Small countries are generally more integrated in world trade in relation to their GDP, as they tend to specialise in a limited number of sectors and, to satisfy domestic demand, they need to import and export more goods and services than larger countries. But in many instances, governments actively take steps in order to open the economy through liberalisation measures, irrespective or their size, geography or resource endowments.

A comparative analysis of indicators of trade liberalisation shows that Japan has gone a long way in strengthening its integration into the world trading system. Its average tariffs are low relative to other G20 countries, it has facilitated trade and it has been promoting multilateral and regional trade liberalisation through WTO and regional trade agreements negotiations. However, foreign operators still face significant non-tariff measures when exporting to Japan, as shown by the World Bank indicators of trade restrictiveness (see below). 
Trade liberalisation policies may be measured though indicators of tariff and non-tariff barriers, participation in regional trade agreements (RTAs), and trade facilitation measures. There is a large body of theory and empirical evidence showing that reduction of levels of protection, harmonisation with international standards and procedures, and transparency of national laws and regulations boost a country's competitiveness and act as catalyst for increased trade. In addition, removal of export restrictions and proactive export promotion policies can help countries diversify their exports by encouraging trade in goods where there exists a comparative advantage or by creating learning opportunities that result in new forms of comparative advantages and therefore attract export-oriented investment (Brenton et al., 2009).

The level of external tariffs is the most obvious indicator of trade liberalisation. As a policy instrument, tariffs are generally transparent and easily measurable. These characteristics also make tariff reductions easier to negotiate compared to the elimination of other border or behind-the-border measures. In addition, information on tariff schedules can be made readily available to foreign economic operators, thus facilitating their trading operations.

Figure 2. World average MFN applied tariff rate, 1986-2009

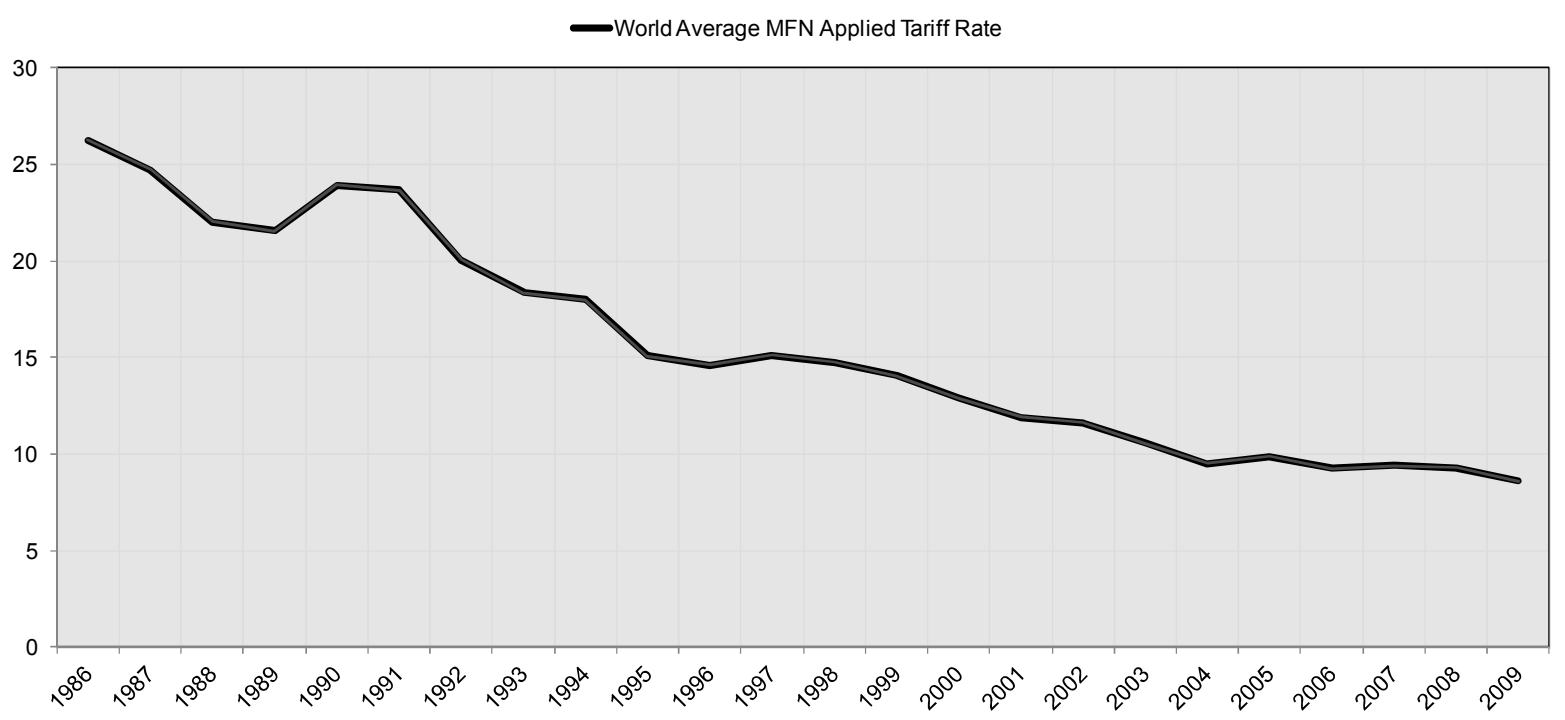

Source: UNCTAD TRAINS database (through WITS); WTO IDB database (through WITS); WTO IDB CD ROMs, various years and Trade Policy Review -- Country Reports in various issues, 1990-2005; UNCTAD Handbook of Trade Control Measures of Developing Countries -- Supplement 1987 and Directory of Import Regimes 1994; World Bank Trade Policy Reform in Developing Countries since 1985, WB Discussion Paper \#267, 1994 and World Development Indicators, 1998-2006; The Uruguay Round: Statistics on Tariffs Concessions Given and Received, 1996; OECD Indicators of Tariff and Non-Tariff Trade Barriers, 1996 and 2000; and IMF Global Monitoring Tariff data file 2004.

Average world tariff levels have steadily decreased, thanks to subsequent rounds of trade liberalisation negotiations in the framework of the General Agreement on Tariffs and Trade (GATT) and then the World Trade Organisation (WTO) - see Figure 2. However, significant differences remain in the level of tariffs across G20 countries, especially for agricultural goods. Figure 3 shows average mostfavoured-nation (MFN) applied tariffs for G20 countries. ${ }^{15}$ This indicator is calculated as the average of the MFN applied tariff rates available at HS 6-digit product level in a country's customs schedule. ${ }^{16}$ Japan's average tariffs are low and generally aligned with those of its main trading partners. However, Japan's tariffs on agricultural goods are on average higher than those in other G20 countries with the exception of Korea, Turkey and India. 
Figure 3. MFN applied tariff (AV+AVE) - Simple average, 2006-2009 (latest)

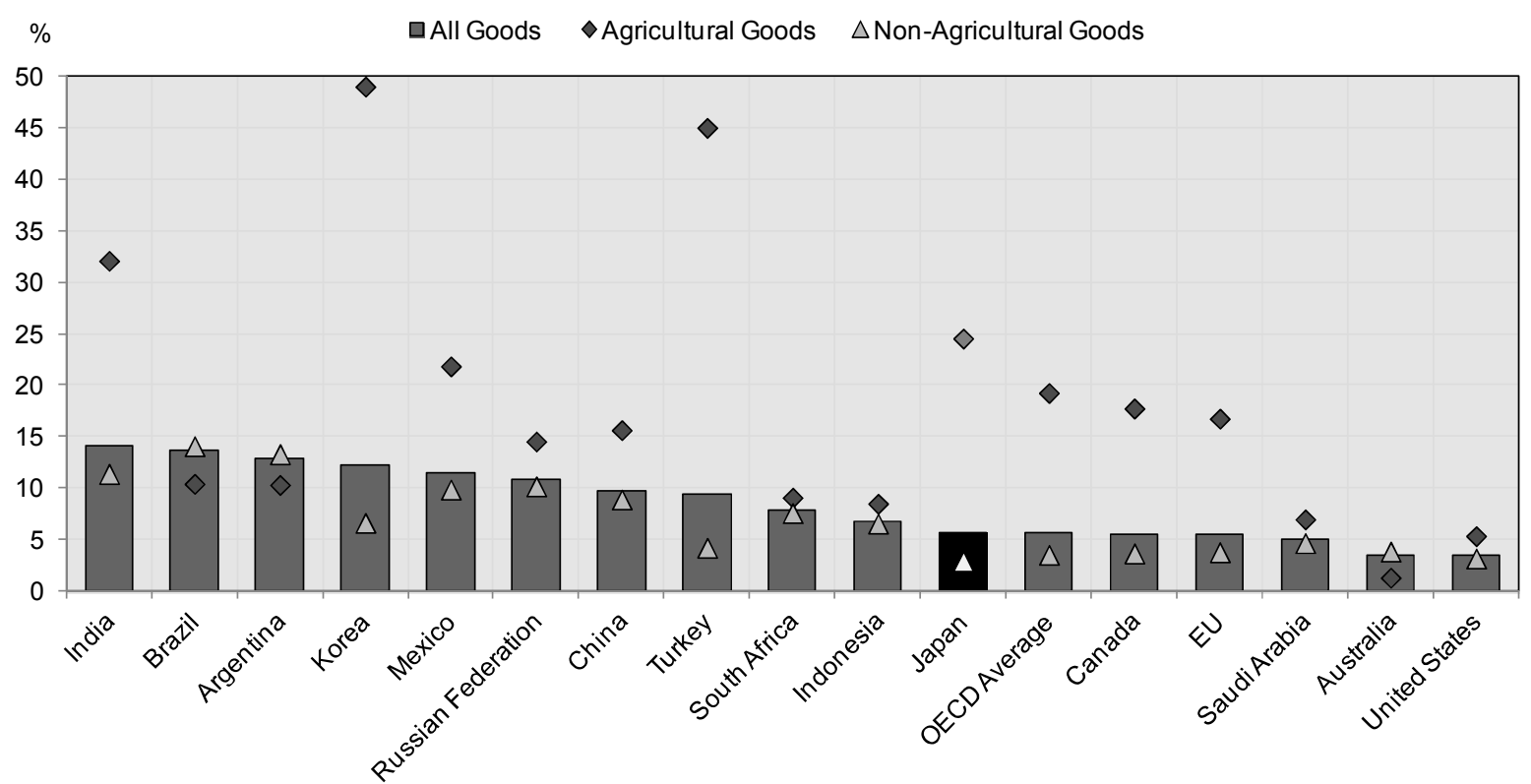

Source: World Bank World Trade Indicators.

The potential benefits deriving from tariff reductions can be offset by the presence of non-tariff measures (NTMs). To date, trade experts have not reached a consensus on the classification of NTMs (OECD, 2005b). This is mainly due to the fact that, unlike tariffs, NTMs are often difficult to identify and their effects on trade flows cannot always be quantified. In addition, no list can be fully exhaustive, because governments are continuously designing new laws, regulations and administrative requirements that can intentionally or unintentionally create obstacles to trade.

The magnitude of non-tariff barriers relative to simple tariff protection can be assessed by comparing values of the tariff trade restrictiveness index (TTRI) and the overall trade restrictiveness index (OTRI), as the latter includes also NTMs (Figure 4). While Japan has a relatively low level of tariffs, it is one of the OECD countries in the G20 with the highest level of overall protection (second only to Mexico). 
Figure 4. Trade barriers in $\mathbf{G 2 0}$ countries

Overall Trade Restrictiveness Index (OTRI) and Tariff Trade Restrictiveness Index (TTRI), 2006-2009 (Latest)

口OTRI (MFN applied tariff+NTMs) - All Goods $\quad$ \TTRI (MFN applied tariff) - All Goods

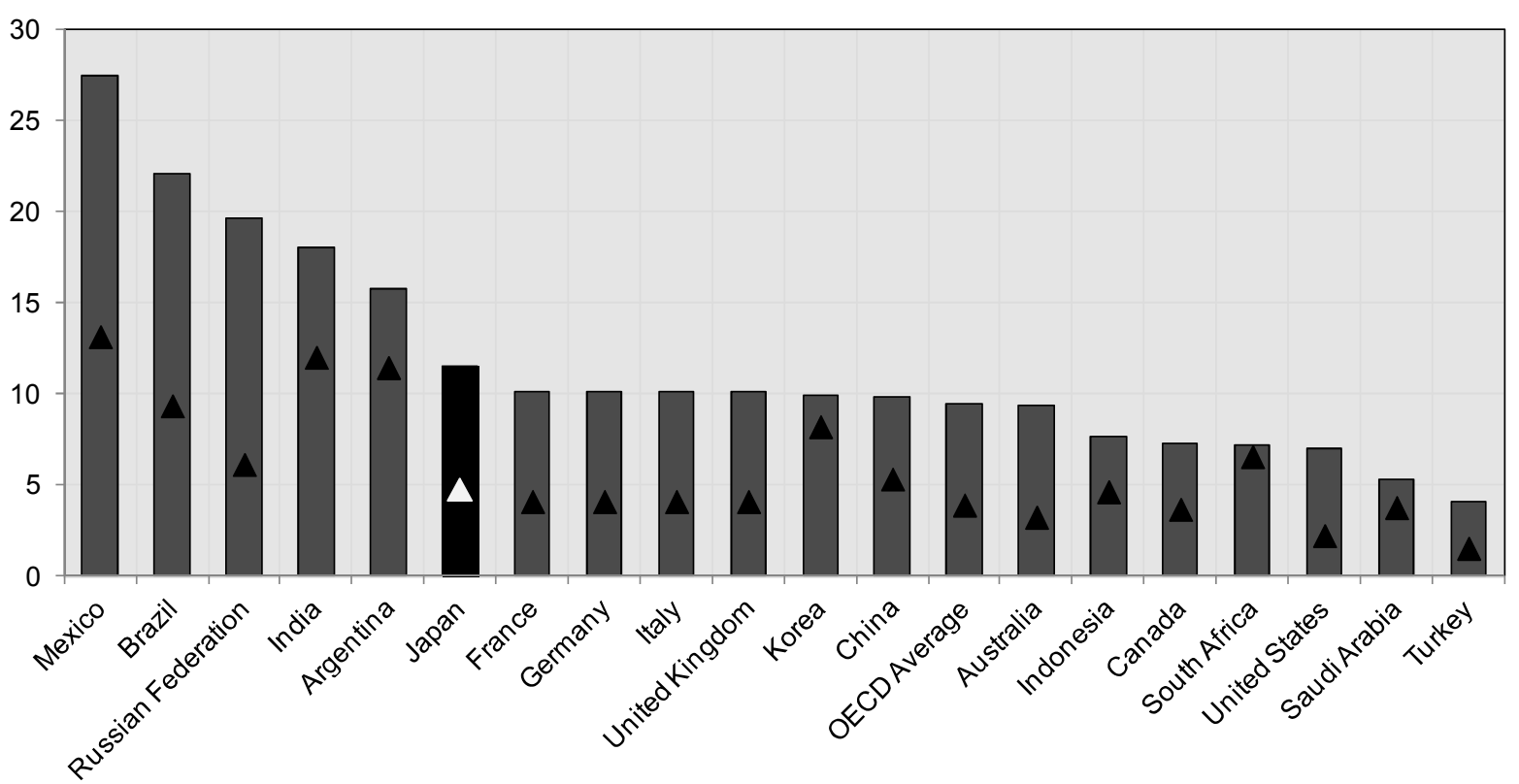

1. The Tariff Trade Restrictiveness Index (TTRI) calculates the equivalent uniform tariff of a country's tariff schedule that would keep domestic import levels constant. The Overall Trade Restrictiveness Index (OTRI) calculates the equivalent uniform tariff of a country's tariff schedule and non-tariff measures (NTMs) that would keep domestic import levels constant.

Source: World Bank World Trade Indicators.

Trade facilitation may also bring significant benefits to importers and exporters. The costs associated with trade procedures and requirements can be very high: (OECD, 2009a) estimates that trade transaction costs can amount to up to $15 \%$ of the value of traded goods. ${ }^{17}$

Among G20 countries, Japan ranks quite high in terms of trade facilitation. Table 1 shows indicators on trading across borders for G20 countries included in the World Bank Doing Business Report. Countries are ranked on the basis of the ease of trading across borders, which may be interpreted as a crude measure of trade facilitation. ${ }^{18}$ By this metric, countries that appear higher in the ranking have a lower level of administrative barriers to trade. Of the OECD countries that are also members of the G20, only Korea, Germany, the United Kingdom and the United States had higher rankings than Japan in 2010. Three OECD Enhanced Engagement countries (India, Brazil, and South Africa) are among those G20 countries where import and export activities are the most burdensome and costly. The Russian Federation has the lowest ranking as regards trade facilitation, with a rank of 162 out of 183 surveyed economies. 
Table 1. Trading across borders, 2010

\begin{tabular}{|c|c|c|c|c|c|c|c|}
\hline & Rank & $\begin{array}{l}\text { Documents to } \\
\text { Export (number) }\end{array}$ & $\begin{array}{l}\text { Time to export } \\
\text { (days) }\end{array}$ & $\begin{array}{c}\text { Cost to export } \\
\text { (USD per container) }\end{array}$ & $\begin{array}{l}\text { Documents to } \\
\text { import (number) }\end{array}$ & $\begin{array}{l}\text { Time to import } \\
\text { (days) }\end{array}$ & $\begin{array}{c}\text { Cost to import } \\
\text { (USD per container) }\end{array}$ \\
\hline$\overline{\text { Russian Federation }}$ & 162 & 8 & 36 & 1850 & 13 & 36 & 1850 \\
\hline South Africa & 149 & 8 & 30 & 1531 & 9 & 35 & 1807 \\
\hline Argentina & 115 & 9 & 13 & 1480 & 7 & 16 & 1810 \\
\hline Brazil & 114 & 8 & 13 & 1790 & 7 & 17 & 1730 \\
\hline India & 100 & 8 & 17 & 1055 & 9 & 20 & 1025 \\
\hline Turkey & 76 & 7 & 14 & 990 & 8 & 15 & 1063 \\
\hline Italy & 59 & 4 & 20 & 1245 & 4 & 18 & 1245 \\
\hline Mexico & 58 & 5 & 12 & 1420 & 4 & 12 & 1880 \\
\hline China & 50 & 7 & 21 & 500 & 5 & 24 & 545 \\
\hline Indonesia & 47 & 5 & 20 & 704 & 6 & 27 & 660 \\
\hline Canada & 41 & 3 & 7 & 1610 & 4 & 11 & 1660 \\
\hline Australia & 29 & 6 & 9 & 1060 & 5 & 8 & 1119 \\
\hline France & 26 & 2 & 9 & 1078 & 2 & 11 & 1248 \\
\hline Japan & 24 & 4 & 10 & 1010 & 5 & 11 & 1060 \\
\hline United States & 20 & 4 & 6 & 1050 & 5 & 5 & 1315 \\
\hline Saudi Arabia & 18 & 5 & 13 & 580 & 5 & 17 & 686 \\
\hline United Kingdom & 15 & 4 & 7 & 950 & 4 & 6 & 1045 \\
\hline Germany & 14 & 4 & 7 & 872 & 5 & 7 & 937 \\
\hline Korea & 8 & 3 & 8 & 790 & 3 & 7 & 790 \\
\hline
\end{tabular}

Source: World Bank Doing Business.

Promoting trade liberalisation through the integration in multilateral and regional trade agreements is another important aspect of a country's trade policy. The multilateral approach in the framework of the WTO is generally deemed to be the best channel to enhance trade liberalisation. However, the current round of WTO negotiations that was launched in 2001 (the Doha Development Agenda) has progressed very slowly and a final agreement is still elusive. Partly as a consequence of this slow pace of advancement, an increasing number of WTO members have engaged in bilateral regional trade agreements (RTAs). ${ }^{19}$

Although bilateral RTAs are not a new phenomenon, their number has been increasing in recent years. Of the RTAs that have been notified to the WTO, 209 were in force at the time of writing. Thirty six additional agreements are either being negotiated or are awaiting ratification, after having been signed. ${ }^{20}$ This phenomenon has become so widespread that a 2005 report on the future of the multilateral trading system commissioned by the then Director-General of the WTO noted that the most favoured nation clause is no longer the rule but rather the exception in the multilateral trading system. ${ }^{21}$ There is no consensus on whether RTAs act as "building blocks" facilitating the creation of a multilateral trading system, or as "stumbling blocks" to multilateral trade liberalisation. In any case, the WTO allows their existence under the condition that they cover substantially all trade.

Although Japan traditionally gave priority to multilateral negotiations, it has engaged in regional or bilateral trade negotiations in recent years. Figure 5 shows the number of RTAs already notified to the WTO by G20 countries as well as those for which an early announcement has been made (meaning that they are still under negotiations or were signed but have not yet been ratified). Japan has a number of agreements that is higher than the average of G20 countries. Japan's RTAs are called Economic Partnership Agreements (EPA). This term underlines the willingness of Japan to go beyond simple trade liberalisation and encompass other aspects of economic integration and openness including investment, workers' mobility as well as other forms of economic and technical co-operation. 
Figure 5. Number of RTAs in $\mathbf{G 2 0}$ countries

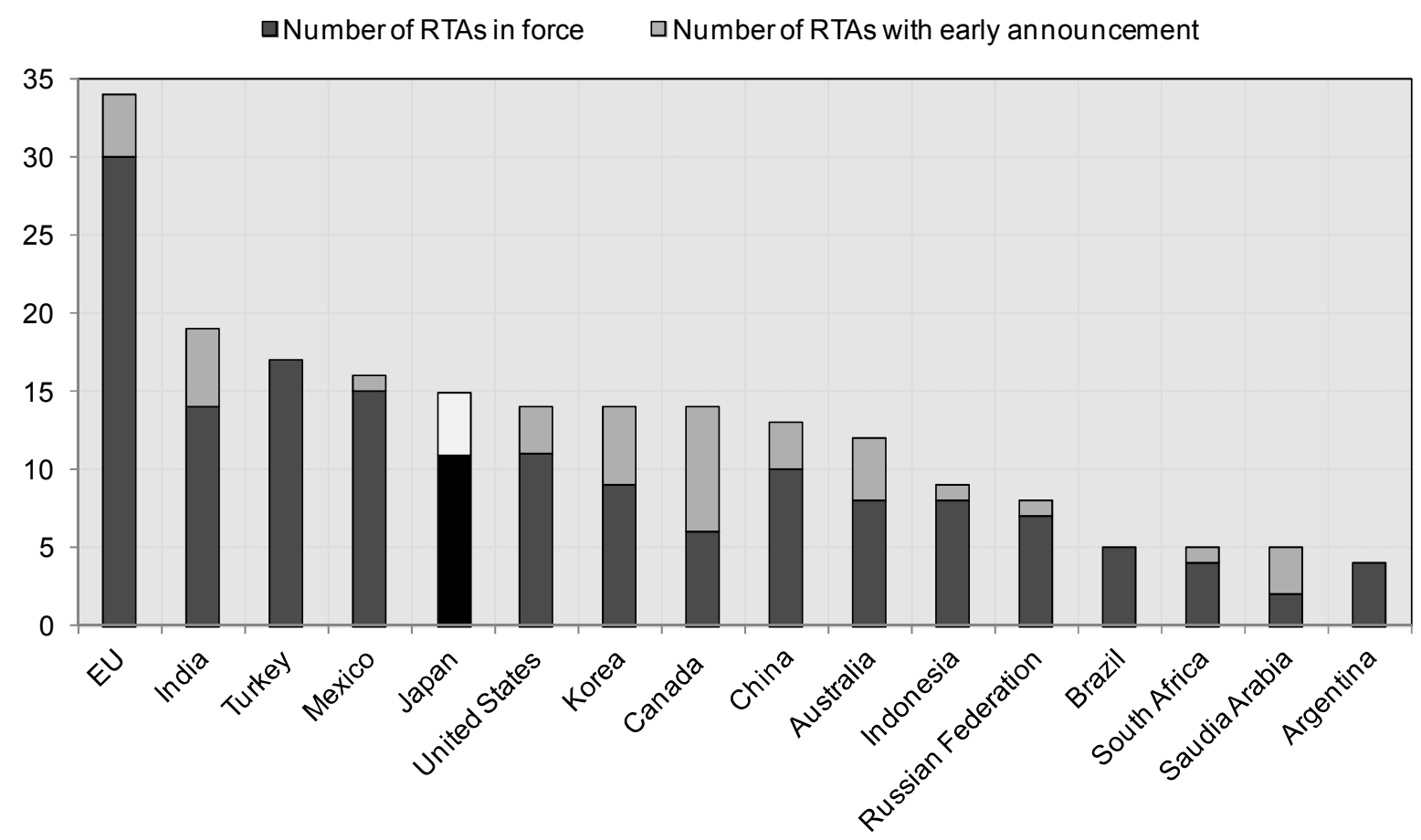

Source: WTO RTA-IS.

In terms of outward orientation, export restrictions may reduce openness by distorting a country's trade prices and quantity (Kim, 2010). WTO Trade Policy Reviews typically cover the following exportrestrictive measures: export prohibitions, export quotas, export licensing, export duties and levies, and minimum prices. Japan has a relatively liberal export regime, as it only applies export licenses, as many other G20 countries $^{22}$ (see Table 2). 
Table 2. Export restrictions in $\mathbf{G} 20$ countries

2006-2009 (Latest)

\begin{tabular}{|c|c|c|c|}
\hline Export license usage $^{1}$ & Export tax usage $^{2}$ & $\begin{array}{l}\text { Presence of export } \\
\text { surrender requirements }\end{array}$ & $\begin{array}{l}\text { Presence of export } \\
\text { repatriation } \\
\text { requirements }\end{array}$ \\
\hline $\begin{array}{l}\text { Australia } \\
\text { Brazil } \\
\text { Canada } \\
\text { China } \\
\text { France } \\
\text { Germany } \\
\text { India } \\
\text { Indonesia } \\
\text { Italy } \\
\text { Japan } \\
\text { Korea Rep. } \\
\text { Mexico } \\
\text { Russian Federation } \\
\text { South Africa } \\
\text { United States }\end{array}$ & $\begin{array}{l}\text { Argentina } \\
\text { Brazil } \\
\text { Canada } \\
\text { China } \\
\text { France } \\
\text { India } \\
\text { Indonesia } \\
\text { Mexico } \\
\text { Russian Federation } \\
\text { Turkey }\end{array}$ & $\begin{array}{l}\text { Argentina } \\
\text { Brazil } \\
\text { India } \\
\text { South Africa } \\
\text { Turkey }\end{array}$ & $\begin{array}{l}\text { Argentina } \\
\text { Brazil } \\
\text { China } \\
\text { India } \\
\text { Korea Rep. } \\
\text { Russian Federation } \\
\text { South Africa } \\
\text { Turkey }\end{array}$ \\
\hline
\end{tabular}

1. Export licence usage indicates if a country requires exporters to obtain licences for products, excluding weapons, nuclear materials, endangered species, and dual use goods.

2. Export tax usage indicates if a country imposes export taxes.

3. Presence of exports surrender requirements indicates if a country imposes requirements that a percentage of export earnings are remitted to the government and converted into local currency.

4. Presence of export repatriation requirements indicates if a country imposes requirements that exporters repatriate a percentage of their revenue.

Source: OECD based on World Bank World Trade Indicators.

In some cases it might be difficult for a country to strengthen its exports, even in an area where it has a comparative advantage. Hence, it may wish to design and implement proactive export promotion policies, aimed at addressing specific problems associated with exporting (OECD, 2005c). The presence of an effective export promotion agency can be instrumental in improving the penetration of local companies in foreign markets. While there are major methodological challenges in attributing increased export earnings to spending on such agencies, some research suggests a positive and sizeable relationship (Ledermann, Olarreaga and Payton, 2006). Export promotion services and programmes can be grouped into four broad categories: country image-building (including promotional events and policy advocacy), export support services (including trade fairs and exporters missions), and market research and publications (Ledermann, Olarreaga and Payton, 2006).

The Japan External Trade Organisation (JETRO) has been quite successful in promoting Japanese exports. Part of this success is due to a set of characteristics that distinguish JETRO from other export promotion agencies, for example (Sakurai, 2007):

- JETRO puts priority on research of foreign countries and employs many researchers to this 
effect. JETRO also attaches high importance to the provision of information to Japanese businesses.

- JETRO maintains close relations with the central government, regional governments and industry organisations.

In addition, since its inception JETRO has been continuously evolving by adapting its function to the increasing openness of Japanese trade (Figure 6).

Figure 6. Changes in Japanese trade and investment: Evolution of JETRO

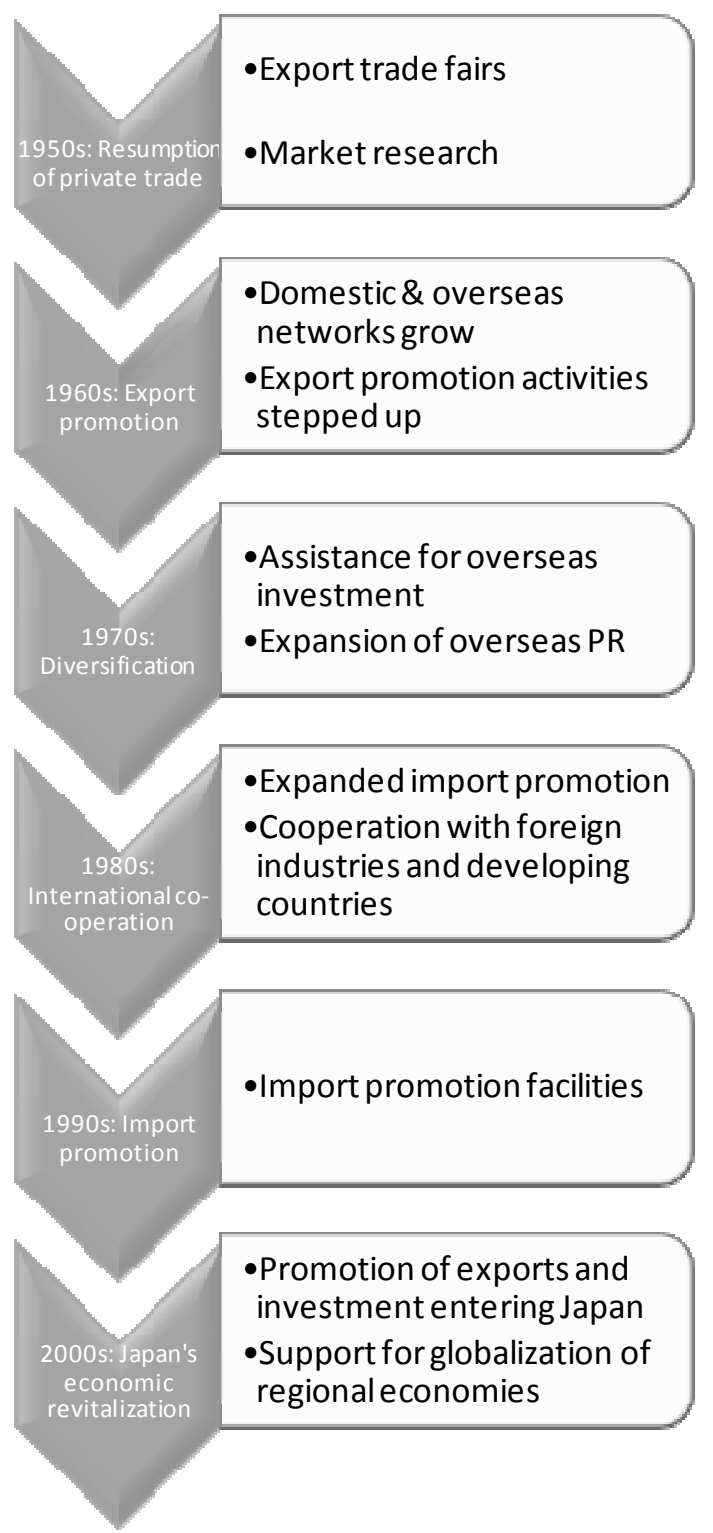

Source: JETRO (www.jetro.go.jp/en/jetro/profile/pdf/jetro.pdf). 


\section{Investment and investment promotion policies}

Ensuring inbound and outbound flows of capital is another important aspect of economic openness that may yield significant benefits to the national economy. A liberal investment regime is only one among many elements that contribute to shaping the overall investment climate. Nevertheless, Kalinova, Palerm and Thomsen (2010) note that a low level of restrictions to foreign investment does appear to be positively correlated with investment attraction, and more restrictive countries tend to receive less FDI relative to the size of their economy (Figure 7).

Figure 7. FDI stocks and FDI index

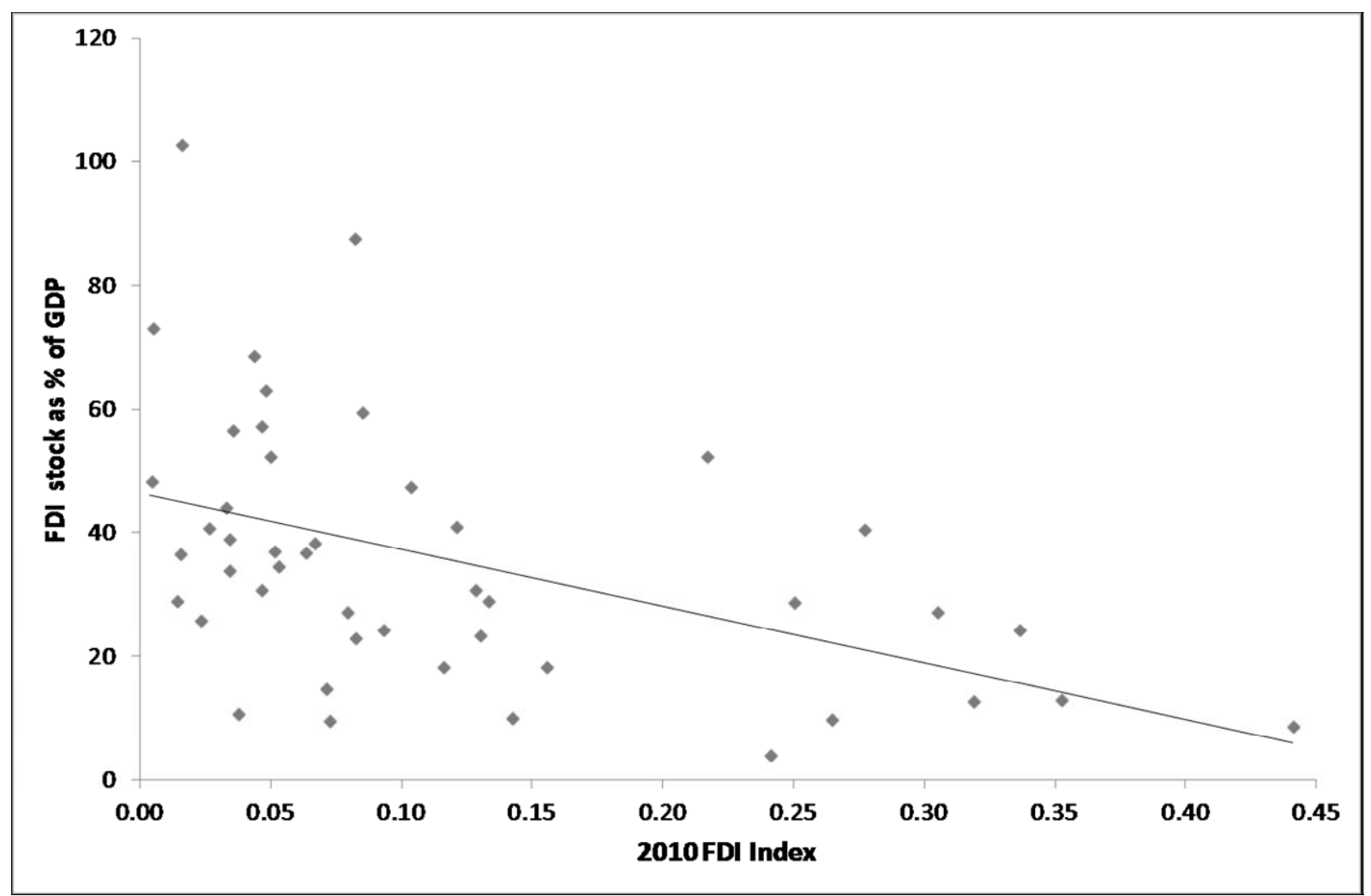

Source: Kalinova, Palerm and Thomson (2010).

Investment liberalisation has been on a continuous trend over the past decades and has become a widespread phenomenon not only in the OECD area but also in emerging, transition and developing economies. Several countries are not only engaged in opening up their economies to inflows of foreign capital, but they also actively encourage such inflows through targeted investment promotion strategies.

The OECD has been at the heart of international efforts to maintain open, transparent and nondiscriminatory investment regimes. Member governments have agreed to establish binding legal instruments in order to enhance their commitment to those principles. ${ }^{23}$ In addition, OECD countries have engaged in a process of policy co-ordination to limit the use of unnecessary restrictive measures and maintain an open investment regime. For example, in 2006 the OECD launched a Freedom of Investment Process, with the objective of helping governments to reconcile the need to preserve and expand an open international investment environment with their duty to safeguard the essential security and interests of their people. The process is very broad in terms of participation and so far has resulted in the publication of a number of instruments, such as the Guidelines for Recipient Country Investment Policies Relating to 
National Security and the OECD Declaration on Sovereign Wealth Funds and Recipient Country Policies, both released in 2008 .

At the G20 level, countries have generally maintained open and liberal investment regimes in the face of the economic crisis, although macroeconomic imbalances may still pose a threat to the process of investment liberalisation. G20 members committed to resist protectionism and promote global trade and investment in subsequent summits throughout 2008 and 2009. In particular, they have mandated the OECD, UNCTAD and WTO to monitor policy developments and report periodically on those commitments. The fourth report issued in November 2010 concluded that "G20 members have continued to honour their pledge not to retreat into investment protectionism. On the contrary, the majority of investment measures taken during the review period carry on the trend towards investment liberalisation and facilitation" (OECD and UNCTAD, 2010).

International investment agreements (IIAs) are important instruments to ensure openness, transparency and predictability of investment frameworks. The most common type of such agreements are bilateral investment treaties (BITs), whose main purpose is to promote and protect investment from one contracting party in the territory of the other contracting party, as usually stated in their titles. Although BITs differ in the legal provisions they include, they are often characterised by a number of key principles, including: broad definition of the term "investment"; inclusion of certain general standards of treatment of foreign investment; more specific standards of protection regarding expropriation and compensation, transfer of funds, and the protection of foreign investment in case of civil strife; national and MFN treatment (although this is frequently limited to the treatment of foreign investment after admission); and ability of States as well as foreign investors to resort to international arbitration (UNCTAD, 2004). IIAs are also instrumental in promoting outward FDI, as they ensure protection as well as fair and equitable treatment of national investors in partner countries.

Japan is one of the countries with the lowest number of BITs and total IIAs (among the G20 countries, only Saudi Arabia and Brazil have negotiated and concluded less IIAs ${ }^{24}$; see Figure 8 ). This reflects the fact that Japan has traditionally preferred a multilateral approach to investment liberalisation and, as a consequence, was slower in negotiating preferential agreements. However, this trend has recently changed and Japan has been engaged in several negotiations of BITs or other types of agreements containing investment provisions. 
Figure 8. G20 Members' International Investment Agreements

Total BITs and other IIAs as of 15 October 2010

口Bilateral Investment Treaties (BITs) $\quad$ OOther IIAs

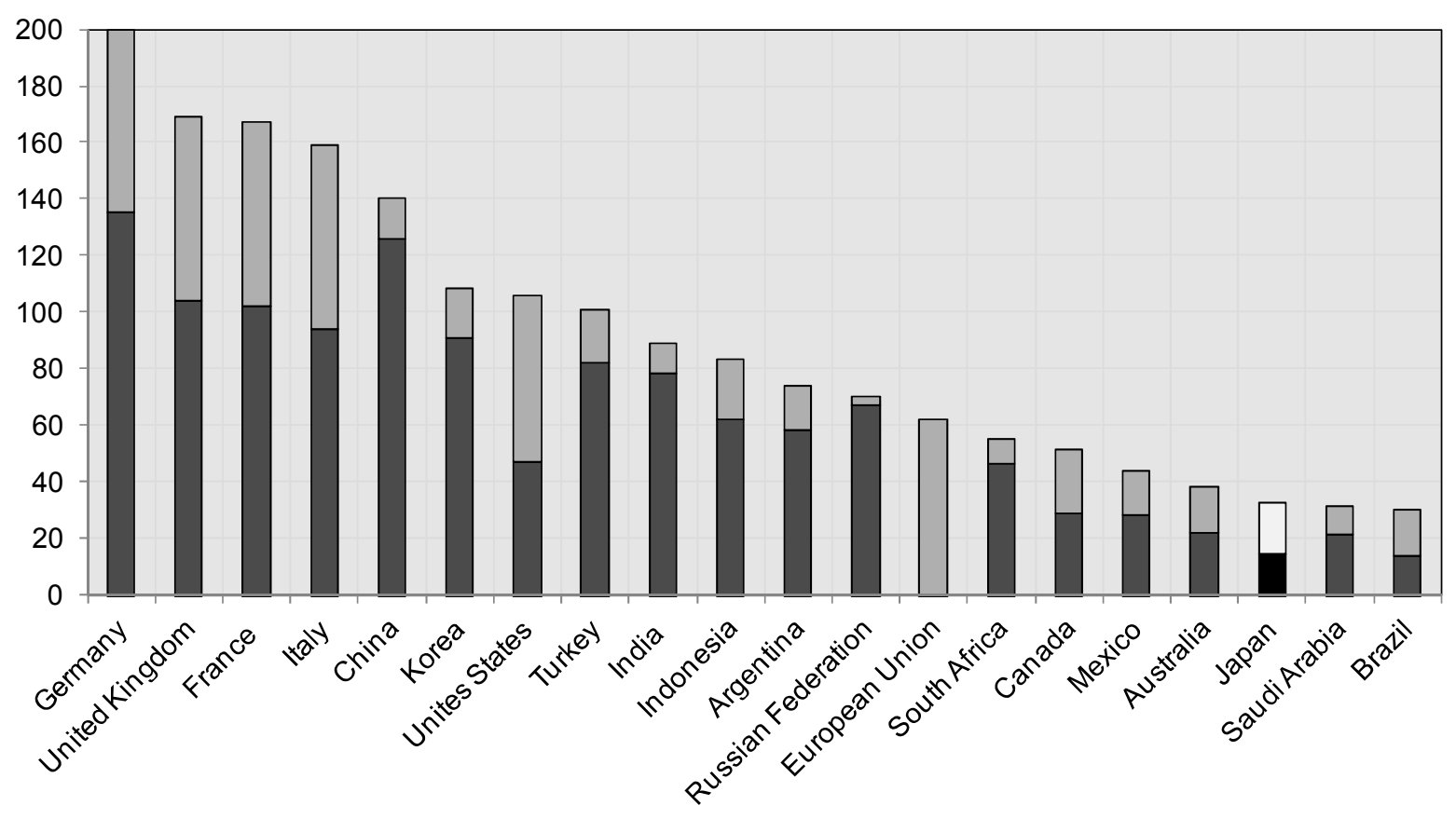

Source: OECD; UNCTAD (2010).

The degree of liberalisation of a country's foreign investment regime may be measured through the OECD FDI Restrictiveness Index (the FDI Index). ${ }^{25}$ This index only covers overt regulatory restrictions to FDI and not other aspects of the regulatory framework. It does not assess the actual enforcement of restrictions, nor does it combine regulations with perceptions of the business climate or implementation issues. Yet, the FDI Index assesses how countries' policies towards FDI affect their attractiveness to foreign investors. Hence, it can help to account variations in countries' success in attracting FDI (Kalinova, Palerm and Thomsen, 2010; Nicoletti et al., 2003).

In the G20 framework, Japan is among the countries with the highest level of restrictions to FDI (Figure 9). It scores significantly higher than the OECD average in being relatively closed to foreign investment, and among those OECD member countries that also participate in the G20, it displays the second highest level of restrictions, after Mexico. This high level of restrictiveness is mainly driven by the persistence of significant foreign equity limits: Japan has the second most restrictive foreign equity regime among all G20 countries, after Indonesia. Since 2006 the OECD has been recommending to the Japanese government that it should ensure that the market for M\&A is fully open to all firms and limit foreign ownership restrictions that are based on national security and strategic reasons (OECD, 2010d). 
Figure 9. FDI Index by country, 2010

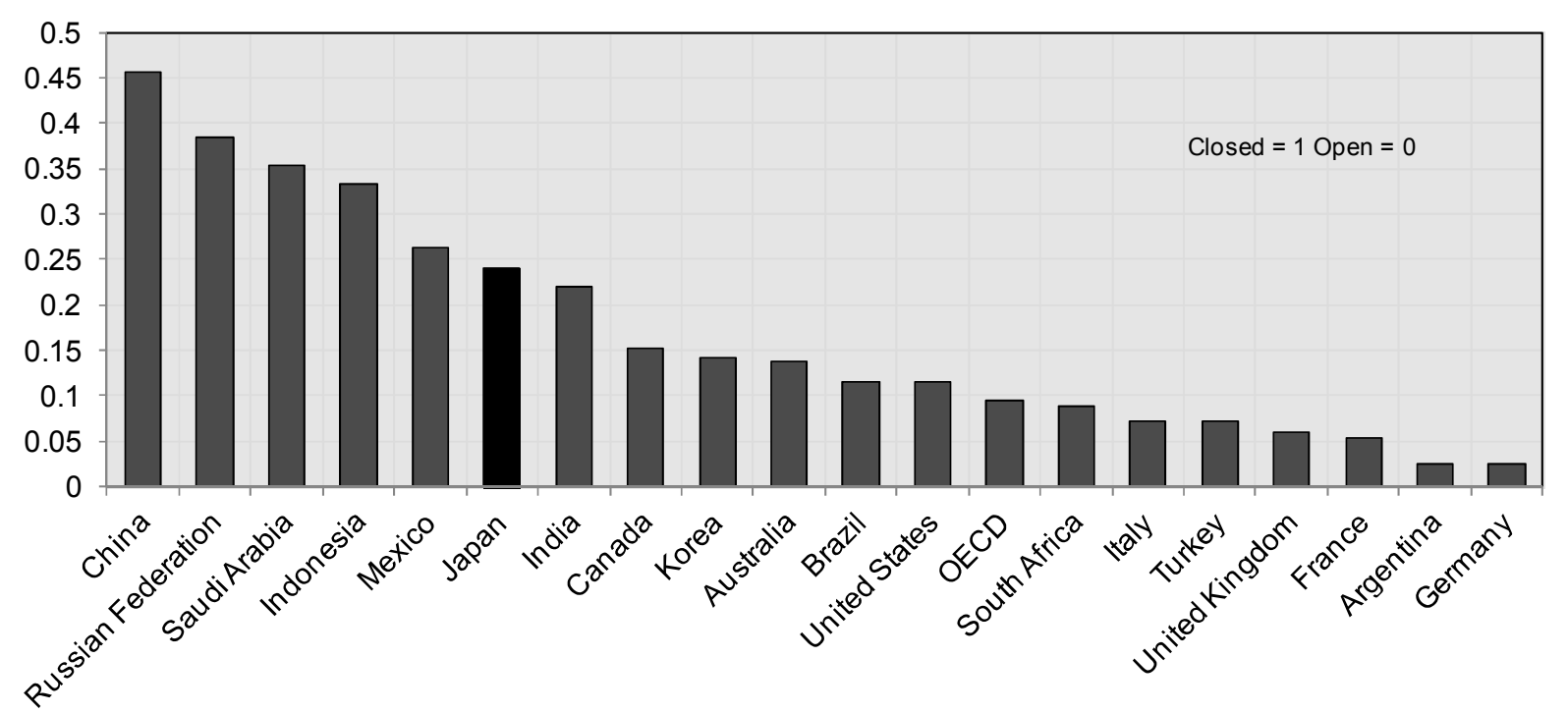

Source: Kalinova, Palerm and Thomson (2010).

Emerging markets have become increasingly attractive for international investment. Results of the World Investment Prospects Survey indicate that the BRICs represented four out of the five top most attractive countries for the location of FDI in 2009 (Figure 10). The United States confirms its lead in terms of investment attractiveness among OECD countries; only 5.7\% of respondents mentioned Japan as a top destination.

Figure 10. Attractiveness of $\mathbf{G} 20$ countries for the location of FDI

$\%$ of company responses

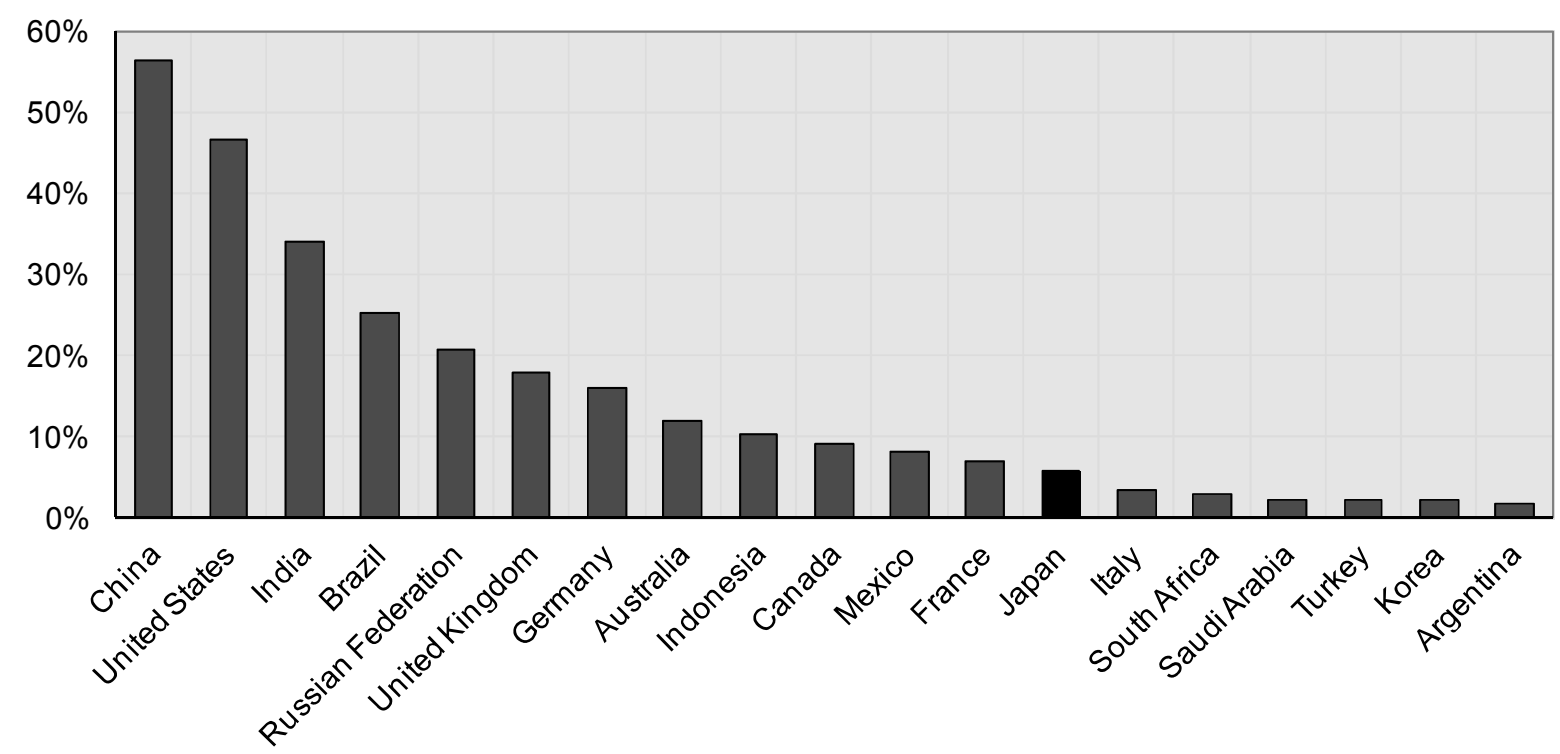

1. This percentage is calculated by the number of times the country has been mentioned, divided by the number of responding companies. Figures may add up to more that $100 \%$ due to the possible multiple responses.

Source: World Investment Prospects Survey, UNCTAD (2009). 
In recent decades international investments have increasingly been in innovation related activities, and this investment has been mainly driven by MNEs. While different internationalisation modes are available for companies, FDI through equity investment often remains the preferred alternative, especially when the investment is aimed at acquiring core competencies. The UNCTAD World Investment Prospects Survey (UNCTAD, 2009) showed that R\&D and headquarters services have become more internationalised in recent years. MNEs play a major role in the internationalisation of $R \& D$ and innovation with their growing investments in $R \& D$ (abroad): the largest $R \& D$ spending MNEs position themselves among the top 10 countries investing in R\&D in 2008 and the aggregate spending of the world's eight largest MNEs in 2008 was larger than the R\&D investments of all individual countries, except for the United States and Japan.

While the majority of R\&D investments are still concentrated in home countries close to MNEs' headquarters, foreign affiliates of MNEs play an important role within multinational networks. R\&D investments by foreign affiliates in the OECD area more than doubled between 1997 and 2007 (reaching USD 89.3 billion). The United States, Germany and the United Kingdom attracted the largest investment projects in $\mathrm{R} \& \mathrm{D}$, although their relative importance decreased over the period considered.

Recent data on international investment projects show that emerging countries in the G20 attracted considerable investment in innovation related business functions, such as headquarters and R\&D (Figure 11). Among OECD countries in the G20, the United States and the United Kingdom (and France and Germany to a lesser extent) also attracted quite significant investments, while the number of greenfield projects in innovation related activities in Japan was relatively low.

Figure 11. Number of greenfield projects in R\&D

$\%$ of world total, January 2003 to June 2010

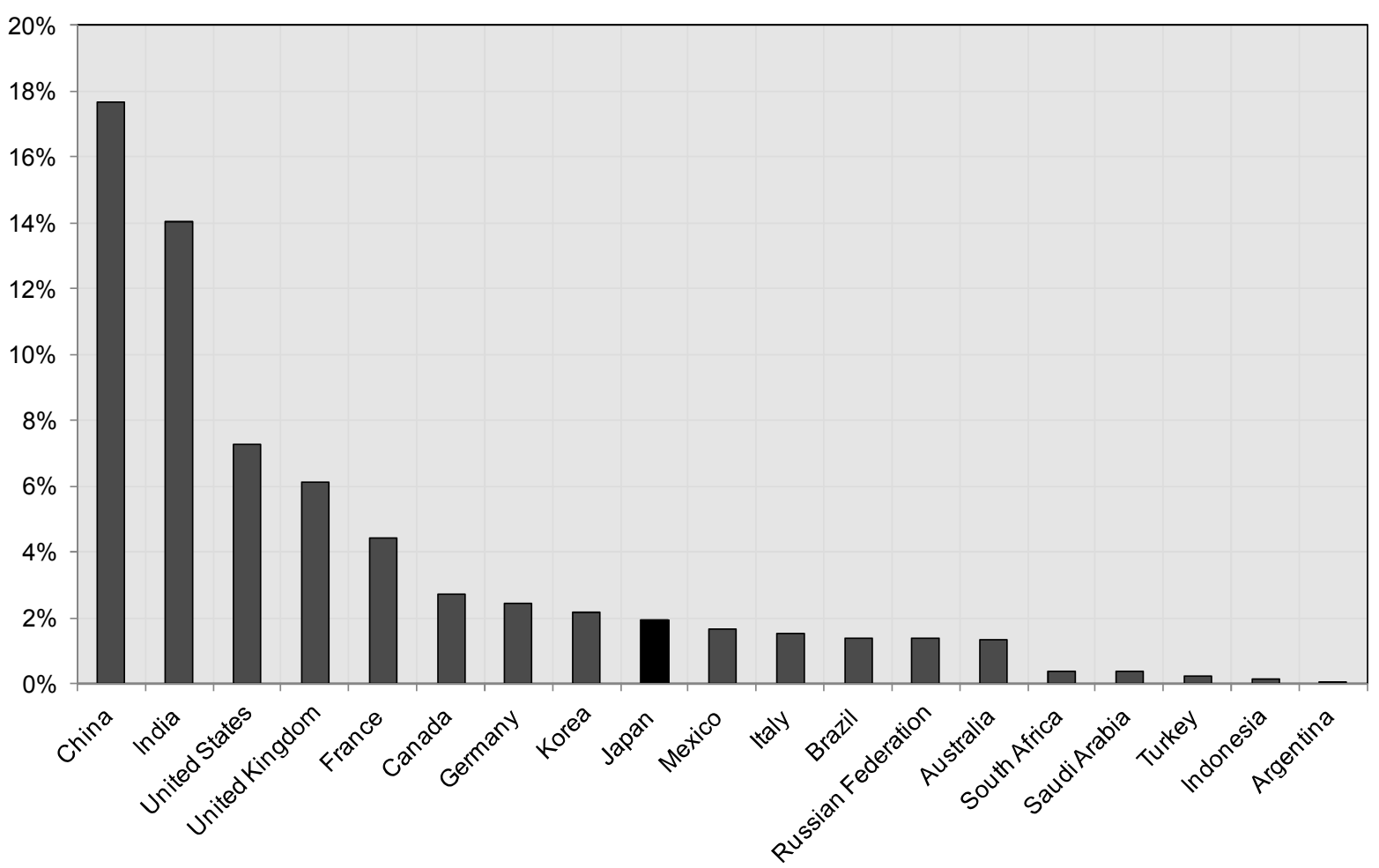

Source: FDI Markets database. 


\section{DSTI/DOC(2011)2}

Attractiveness for international investments is a policy priority in most countries: developed countries hope that these new investments compensate for their decreasing comparative advantage in more labour intensive activities, while emerging countries consider these activities as an important leverage for their own economic development. In terms of the right policy mix, attractiveness for investment in innovation requires a close co-ordination/integration of innovation policy and inward investment promotion policy. Innovation policy aims to foster the innovation performance and outcomes of host countries, while investment promotion attempts to create a positive image of the country as a location for international investment. An attractive marketing of a host country that is not based on strong economic fundamentals will, however, be rapidly perceived as non-credible by potential investors.

By targeting specific types of investors, formulating marketing and information instruments and providing tailored services, investment promotion can result in better outcomes. Investment Promotion Agencies (IPA), typically in charge of these policies, should work closely with other government ministries and agencies in charge of science, technology and innovation, industrial, trade, education and labour policy, etc. (OECD, 2011a).

Evidence shows that most countries use either an industry approach or a business functions approach in formulating their attraction strategies, or most commonly a combination of the two. For example, results of an OECD 2009 survey and a review of Investment Promotion Agencies' Annual Reports and websites shows that France focuses on innovation related activities, high-tech manufacturing and high added value services. In addition, since 2003 the country has been implementing a global attractiveness policy and attraction of talents, skills and expertise are considered as a major priority of this policy. In the case of Korea, the main objective of the investment promotion agency is to promote the country as a regional hub in North-East Asia, acting as a link between Pacific and continental economies. High added value activities are also considered as a priority.

In recent times Japan has used both a business function and industrial approach in its strategies to attract investment. The "Industrial Structural Vision 2010" has among its objectives to attract high addedvalue functions from abroad (e.g. Asian headquarters of multinational enterprises; investment in R\&D). In addition, the strategy identifies a number of important sectors for investment: infrastructure; environmental and energy-saving technologies; cultural industries (including fashion, digital contents, food and tourism); medical care, and other advanced technology areas (e.g. robotics, IT, nanotechnology, and biopharmaceutical). 


\section{Box 3. Openness to trade and investment: Chile}

Several international rankings of country's competitiveness and economic performance show that Chile has displayed increasingly strong economic growth as well as openness to trade and investment. In 2010 the country joined the OECD, the first South American country to do so. Chile's GDP growth averaged 7\% in the period 20052008. Chile's economy was ranked the 10th freest in the world in the Heritage Foundation's 2010 Index of Economic Freedom, with trade and investment freedom contributing substantially to this result.

Like several other countries in Latin America, Chile adopted an import substitution industrialisation strategy (ISIS) between the 1930s and 1970s, and this resulted in modest economic growth. For example, in the decade 1960-1970 the country experienced an average annual growth rate close to $0 \%$. The national economy was kept closed from the rest of the world, through high tariff and non-tariff measures, state intervention (also industry nationalisations) and price controls. In particular, trade policy recurred to the typical instruments of ISIS, including import tariffs, import and export quotas, import permits, noninterest-bearing import deposits, and a system of multiple exchange rates. The economy was highly concentrated on the copper sector, which accounted for $70 \%$ of exports in 1970 .

The direction of economic policy changed dramatically from 1973, as the country was steered decisively towards a market-oriented economy. Reforms were inspired by a group of young economists, the "Chicago boys" (as they had been trained at the University of Chicago in the United States). They pushed for an ambitious plan of macroeconomic stabilisation, fiscal, tax and financial reform, and privatisation.

Trade and investment policy liberalisation was a key component of the reform agenda. All trade restrictions other than tariffs where immediately removed in 1973. Tariffs were reduced from an average of $94 \%$ to a uniform rate of $10 \%$ between 1973 and 1979. In addition, the FDI regime was completely liberalised in 1974 and foreign capital was actually encouraged to flow into the country, especially in some industries. An economic recession hit the country in 1981, and led to the reversal of some of the liberalisation policies that had been introduced in the previous decade. For example, the uniform tariff rate was raised to $20 \%$ in March 1983 and to 35\% in September 1984. However, this proved to be only a temporary reversal, and the path of trade liberalisation was steadily taken again as of 1985. This resulted in continuous tariff cuts and the introduction of export promotion policies.

Since 1990, subsequent democratic governments have maintained and furthered trade and investment openness. Average MFN applied rates were cut from 15\% in 1990 to $6 \%$ in 2003 (and have since remained at that level). In addition, the country engaged in a series of free trade agreements negotiations, first with other Latin American countries (Mexico, Andean Community, Central America and Mercosur) and then with other important trading partners such the European Union and the United States. The decade of the 2000s witnessed an increasing involvement of Chile with Asian countries, which resulted in preferential trade agreements with Korea (2003); China (2005); Japan (2007). As of January 2009, Chile had one of the largest numbers of agreements and preferential partners in the world, with a total of 21 RTAs signed with 57 trading partners (WTO, 2009).

Export promotion policies also played an important role in diversifying exports and providing an incentive to exporters to introduce new products and move away from traditional ones. This has been the case especially since 1990, as export promotion policies have been brought into line with WTO Agreements and the drawback mechanisms were modified or withdrawn. In the same period, ProChile (the export promotion agency) has continued to be active in operating programmes aimed at promoting exports and broadening the export base.

Chile has also maintained a liberal investment regime. In the late 1990s measures were put in place to discourage short-term inflows, but these capital controls were abolished in 2001. In the 2010 OECD FDI Restrictiveness Index Chile had a score of 0.081 , which was below the OECD average (on a scale ranging from $1=$ closed to $0=$ open).

Thanks to the maintenance of macroeconomic stability and the continuous process of trade and investment liberalisation, Chile's economy grew at sustained positive rates over the past decades, in parallel with the increasing rate of openness of the economy (see figure below). In addition, the country significantly managed to diversify its export structure, both in terms of goods and geographic destinations. In particular, Chile has been increasingly engaging its partners in preferential trade agreements, especially in Latin America and Asia. 


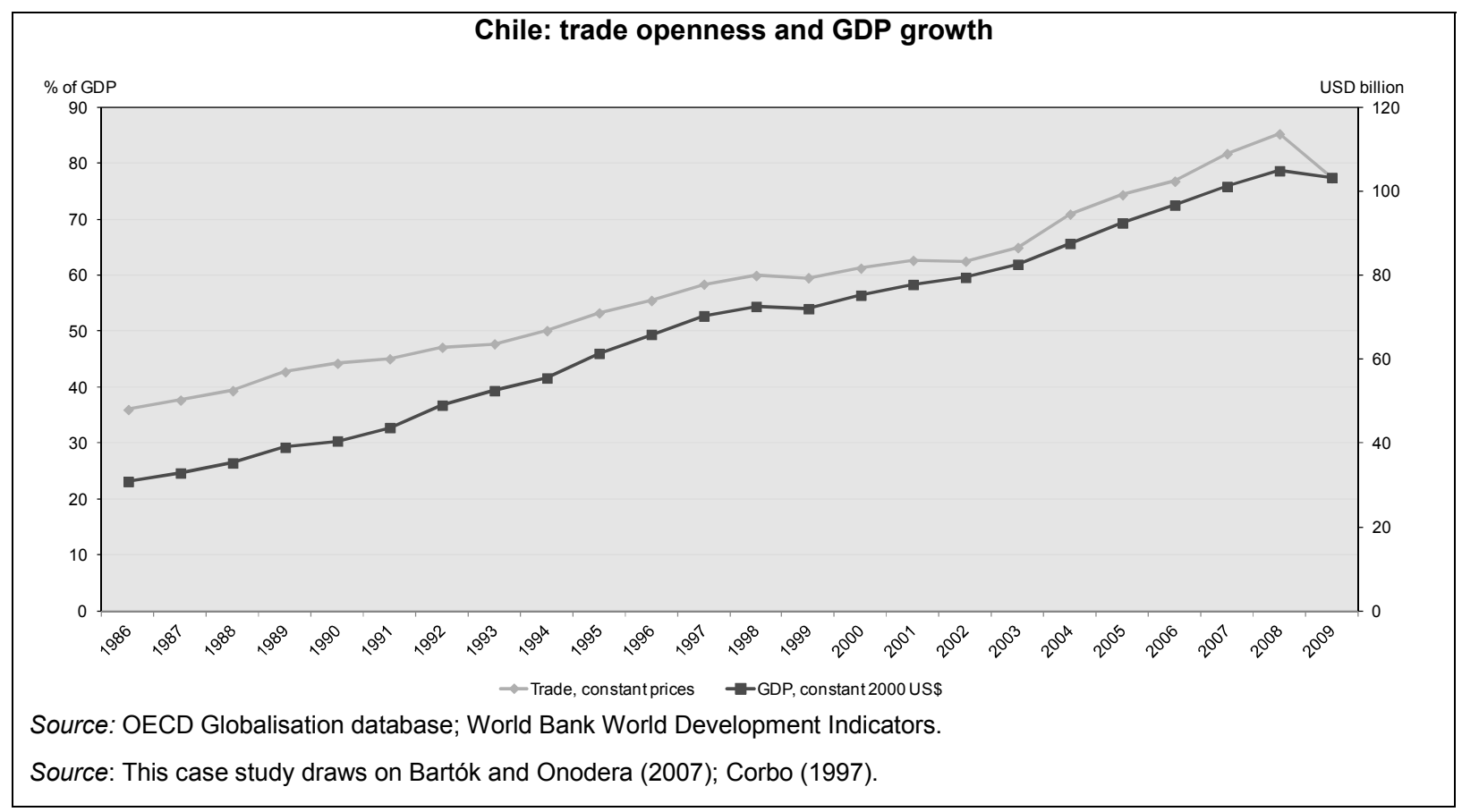

\section{Box 4. The gains from regional economic integration: the European Union}

The European Economic Community was created in 1957 by the Treaty of Rome. Since then, it has grown from 6 to 27 member states (17 of which now share a common currency), it removed all tariffs in intra-regional trade and strove to eliminate internal non-tariff barriers. Over time it evolved in the European Union (EU) with the goal of creating an "ever closer union" among the peoples of Europe and laid down the "four freedoms" for an internal market where goods, services, people and capital can move freely. Regional integration has produced remarkable gains for the economies of the member states, and brought prosperity and a single market for goods among 500 million consumers that works fairly well.

In particular, the single market has delivered major benefits for EU citizens. By removing barriers to trade, it has given consumers a better range of goods and services, often at lower prices and higher quality. For businesses, it has created a larger pool of suppliers, helping them to be more competitive on world markets. The harmonisation of technical standards and the principle of mutual recognition for goods mean that most of the time businesses now have to comply with only one set of rules. European Commission estimates suggest that the first two decades of the internal market have generated a permanent rise of around $2 \%$ in the level of EU GDP and have boosted employment by almost 1\% (Ilzkovitz et al., 2007). Other studies (HM Treasury, 2007; Notaro, 2002) have shown that it has contributed to a quadrupling of foreign direct investment within Europe, an increase in foreign direct investment into Europe as foreign companies try to take advantage of the internal market, higher productivity in various sectors of the economy and a reduction in price-cost margins.

Increased regional economic integration has also been one of the main drivers of the impressive increase in intra-EU trade. Over the period $1960-2000$ intra-EU trade grew by $1200 \%$ in real terms $(6.7 \%$ per annum), compared with $730 \%$ growth of the EU countries' trade with the rest of the world (Badinger and Breuss, 2004). Using a gravity model, Badinger and Breuss (2004) estimate the relative contribution of income growth, income convergence, and the reduction of tariffs and trade costs to the growth of intra-EU trade. They find that while income growth was the main force, European integration and GATT/WTO liberalisation also played a substantial trade-creating role, accounting for approximately one-quarter of the growth of intra-EU trade. Similarly a diagnostic test simulating the effects of EU membership by the HM Treasury (2005) estimated that trade between member states was boosted by $38 \%$ by EU membership, with only $5 \%$ of trade diverted from non-member countries. In addition, the simulation finds a positive "Single Market effect" of $9 \%$, with a caveat that the latter effect may actually be underestimated. The figures below show trends in exports of goods and services and FDI in the EU, as well as changes in the "border effect" on trade. 
DSTI/DOC(2011)2

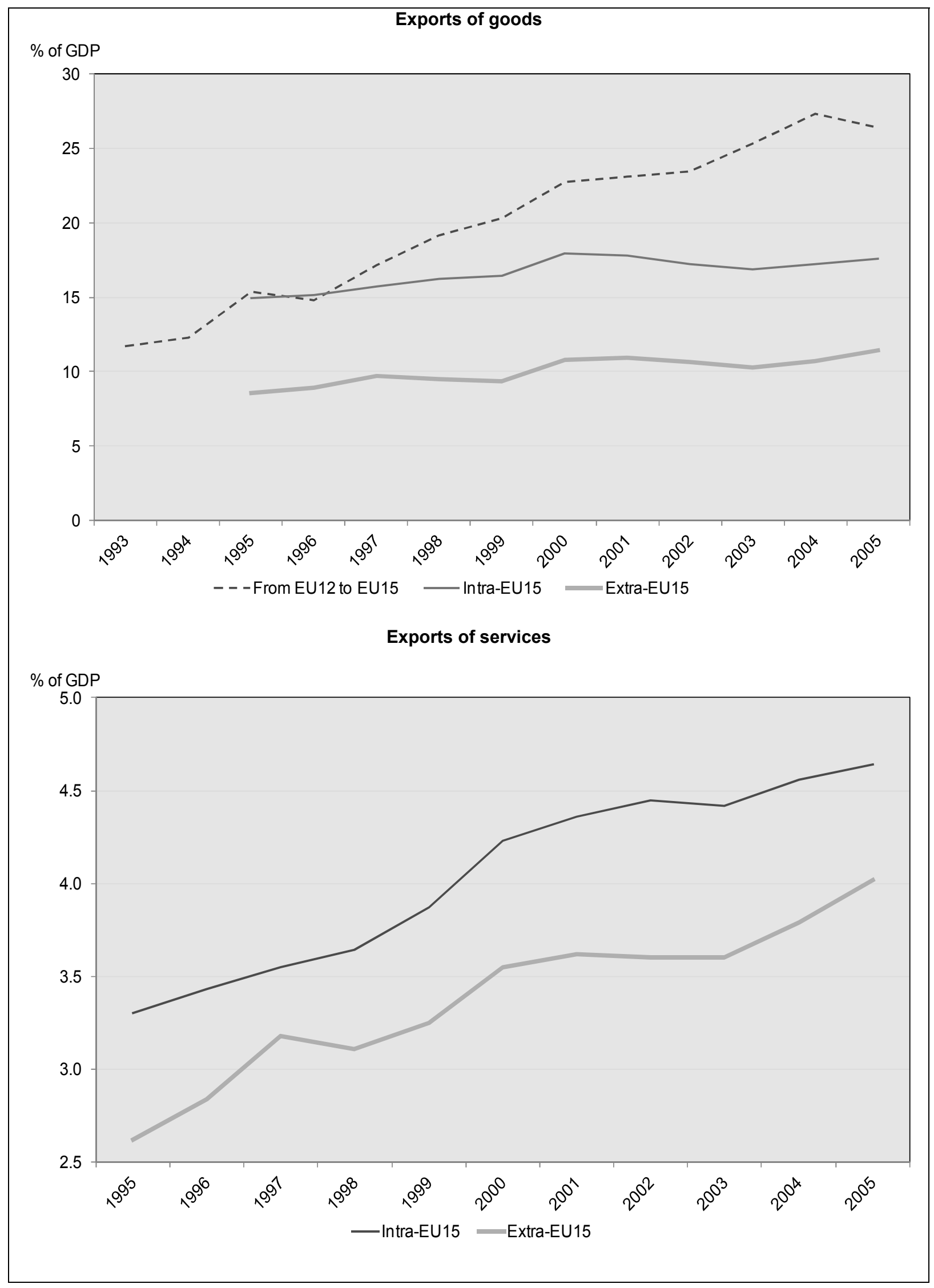




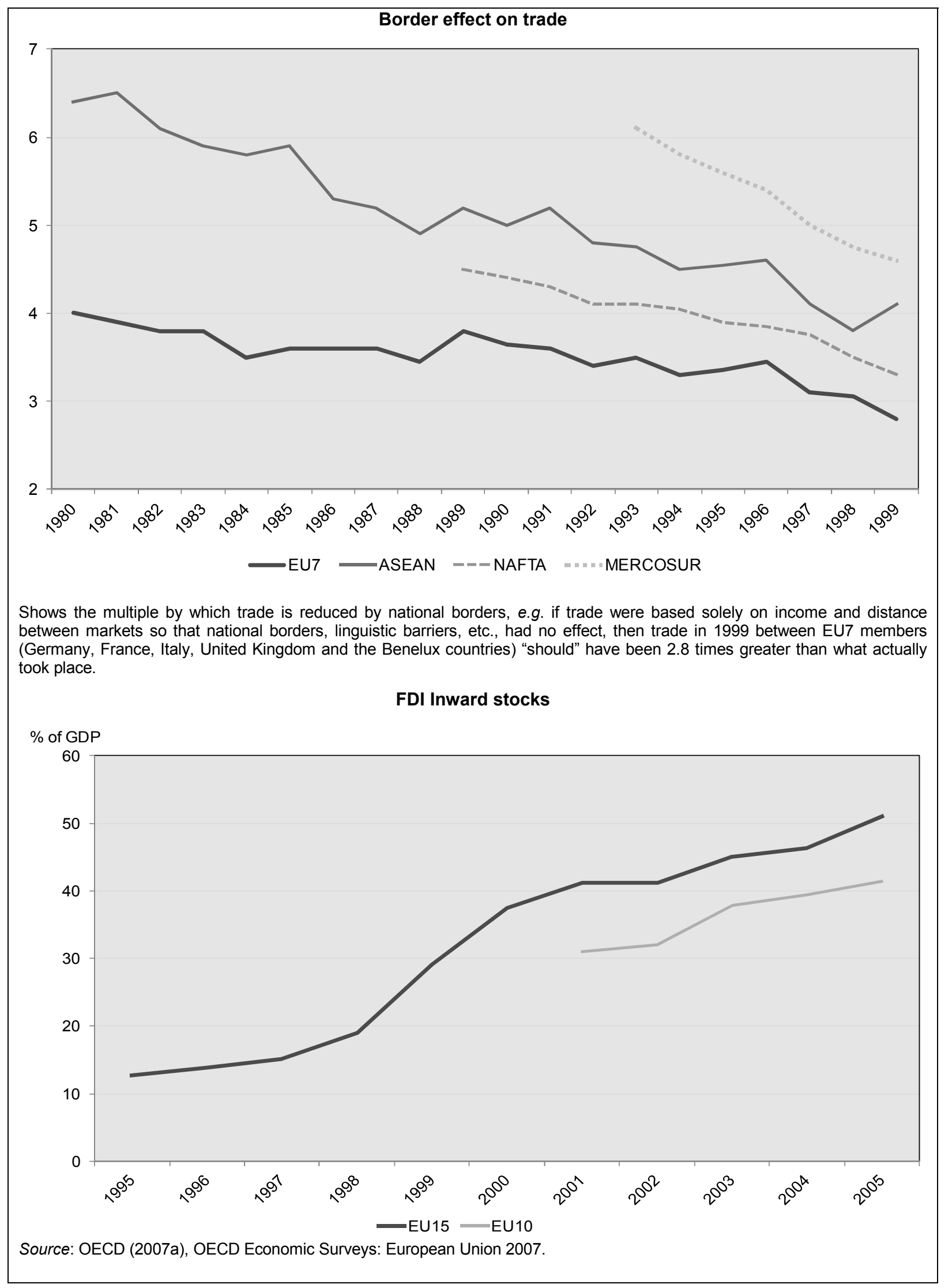


In addition to the "hard" gains deriving from regional integration, thanks to its economic weight the EU plays an important role in the global trade system and in international economic governance. For example, not only have standardisation, technical regulations and conformity assessment been instrumental in removing barriers within the EU internal market through harmonisation and mutual recognition. The EU has also adopted a policy of harmonisation of technical regulations and standards with accession and "neighbouring" countries, while it favours convergence towards international standards in agreements with more remote countries such as Mexico and Chile (Lesser, 2007). The EU is also a leading participant in international standardisation, and has a strong commitment to it. The EU also has a strong influence in the preparation of international standards, as EU member states' interests are aligned thus helping the Union's effectiveness in international standardisation fora (CEN and CENELEC, 2010).

Source: This case study draws mainly on OECD (2009b), OECD Economy Surveys: European Union; OECD (2007), OECD Economy Surveys: European Union.

\section{Tax policy}

Governments need to find a balance between the desire to offer a competitive tax environment for FDI and the need to ensure that an appropriate share of domestic tax is collected from MNEs. In doing this, concerns over the international competitiveness of the tax system together with claims by business groups that accommodating treatment is available elsewhere may run counter to possible revenue requirements and fair domestic competition arguments which call for the same tax treatment of domestic and foreignowned business.

The influence of tax on inbound FDI is complex and depends on a number of factors which are difficult to measure. Corporate taxation may have a negative effect on investment by reducing its after-tax return. This affects both domestic and foreign investment. In addition to domestic tax rates, the tax treatment of cross-border income may also have an impact on FDI. Hajkova et al. (2006) find that a one percentage point increase in the effective corporate tax rate of the host country reduces its FDI stocks by $1 \%$ to $2 \%$. Estimates vary significantly, however, with most studies finding decreases in FDI inflows in the range of $0 \%$ to $5 \%$ for the same increase in tax rates. This variation partly reflects differences between the industries and countries being examined, or the time periods concerned. Some recent studies find, for example, that FDI is becoming increasingly sensitive to taxation, reflecting the increasing mobility of capital as non-tax barriers to FDI are removed (OECD, 2007b).

However, both the empirical literature and business perception surveys have consistently shown that taxation is only one of many aspects of the business environment that investors consider when making their location decisions. In fact, government support cannot easily compensate for the negative effects of other factors on investment location decisions (OECD, 2011a). In addition, tax competition between countries may eventually lead to a "race to the bottom" and to significant welfare losses. And although OECD countries have implemented several fiscal schemes to attract foreign investment, in particular in $R \& D$ activities, there is only little evidence on the impacts of such incentives.

OECD analysis of the tax policy mix/structure shows that corporate income taxes are the most harmful for growth as they discourage investment in capital and productivity improvements. They may also create distortions by creating advantages for specific activities. OECD (2010e) issued the following recommendations:

- Reducing corporate income tax may be preferable to reducing personal income tax on dividends and capital gains when the objective is to reduce distortions that hold back the level of domestic investment and to attract FDI. 
- Lowering the corporate tax rate and removing differential tax treatment may also improve the quality of investment by reducing possible tax-induced distortions in the choice of assets.

- Providing greater certainty and availability in the application of corporate income taxes may lead to higher investment and growth performance.

The Tax Policy chapter of the OECD Policy Framework for Investment (PFI) may also be used by governments to assess advantages and disadvantages of alternative tax policy choices and design options in meeting the objective of offering an attractive tax system while maintaining an adequate level of tax revenues.

Over the past decade OECD countries have undertaken several reforms of their tax systems. In particular, the objectives of most corporate tax reforms have been to promote competition and avoid economic distortions. Reforms have typically involved cuts in statutory rates or broadening of the tax base in order to improve efficiency, while maintaining the level of tax revenues (OECD, 2010e).

Several indicators may be used to measure the tax burden of FDI. However, the comparison of tax rates and regimes across countries is not straightforward, since different tax rates can be considered. The most popular comparison is based on statutory "headline" corporate income tax rates (CIT). Others are based on tax codes and are ex-ante or "forward looking"; others are based on tax payments and are "backward looking". The two most widely used forward-looking indicators are the effective marginal tax rates (EMTR) and the effective average tax rates (EATR). Both measure the wedge between the pre-tax rate of return earned by a company and the post-tax rate of return earned by its foreign parent. But while EMTR applies to a marginal investment project that earns the minimum required rate of return after tax, the EATR applies to an infra-marginal investment project that earns some economic rent (Hajkova et al., 2006). In the context of international competition to attract FDI, the EATR is in principle the relevant rate for analysing discrete investment choices, such as where to locate. This is because the EATR is the proportionate difference of the net present value of a profitable investment project in the absence of tax and the net present value of the same investment in the presence of $\operatorname{tax}(\mathrm{OECD}, 2007 \mathrm{c})$.

Statutory tax rates may differ significantly from effective tax rates, to the extent that taxable profits differ from true economic profits. Figure 12 and Figure 13 show statutory CIT rates and EATR for OECD countries that are also in the G20, respectively. ${ }^{26}$ In both cases, Japan displays the highest average corporate tax rate. The latest OECD Economic Surveys of Japan stressed that as part of a comprehensive tax reform, Japan should consider broadening the corporate tax base, which would then provide scope for cutting rates by lowering the proportion of firms that do not pay taxes (OECD, 2009c; OECD, 2008e). 
Figure 12. Corporate income tax rate, 2010

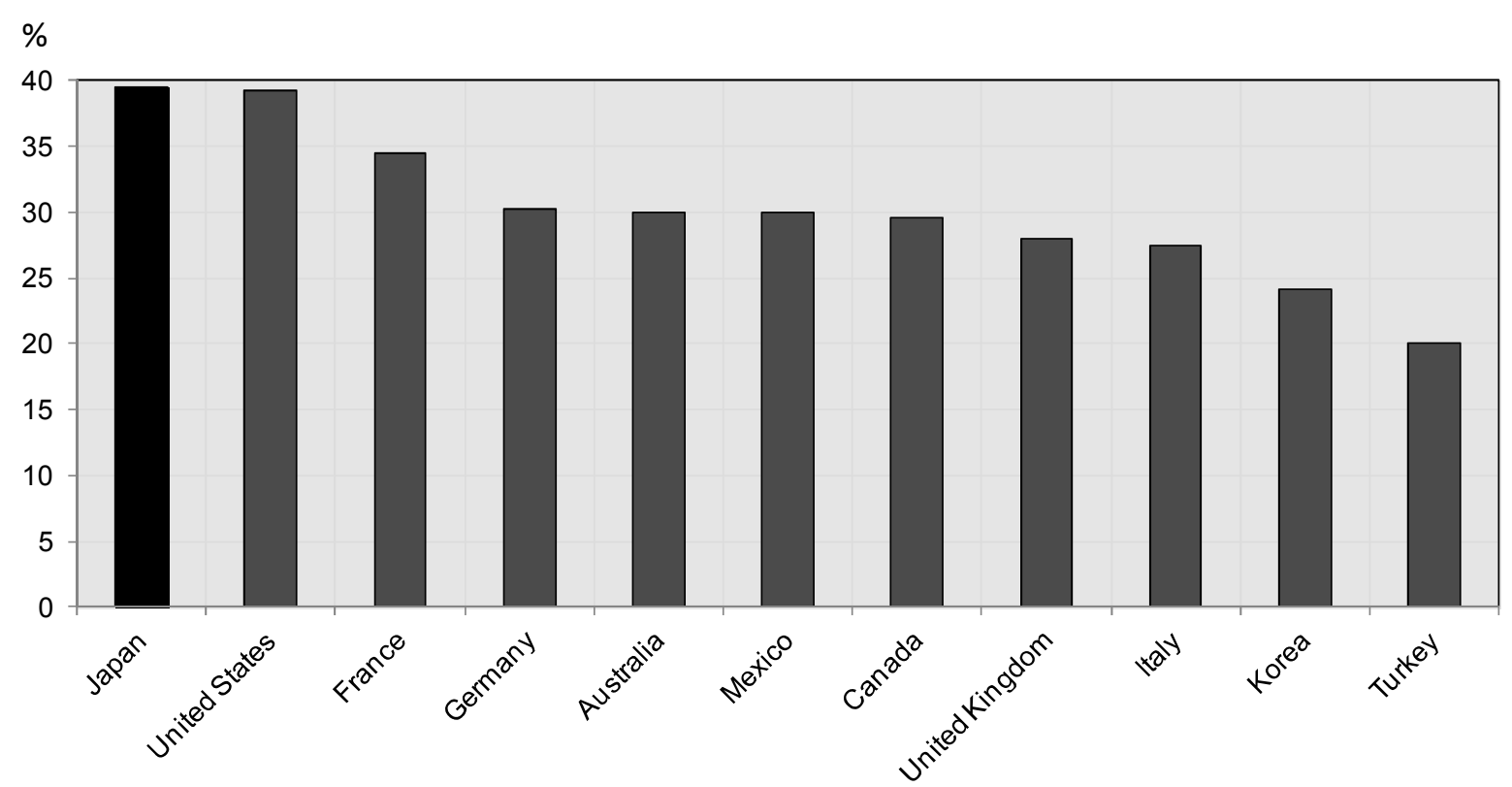

1. This shows the basic combined central and sub-central (statutory) corporate income tax rate given by the adjusted central government rate plus the sub-central rate.

Source: OECD Tax Database.

Figure 13. Effective average tax rate

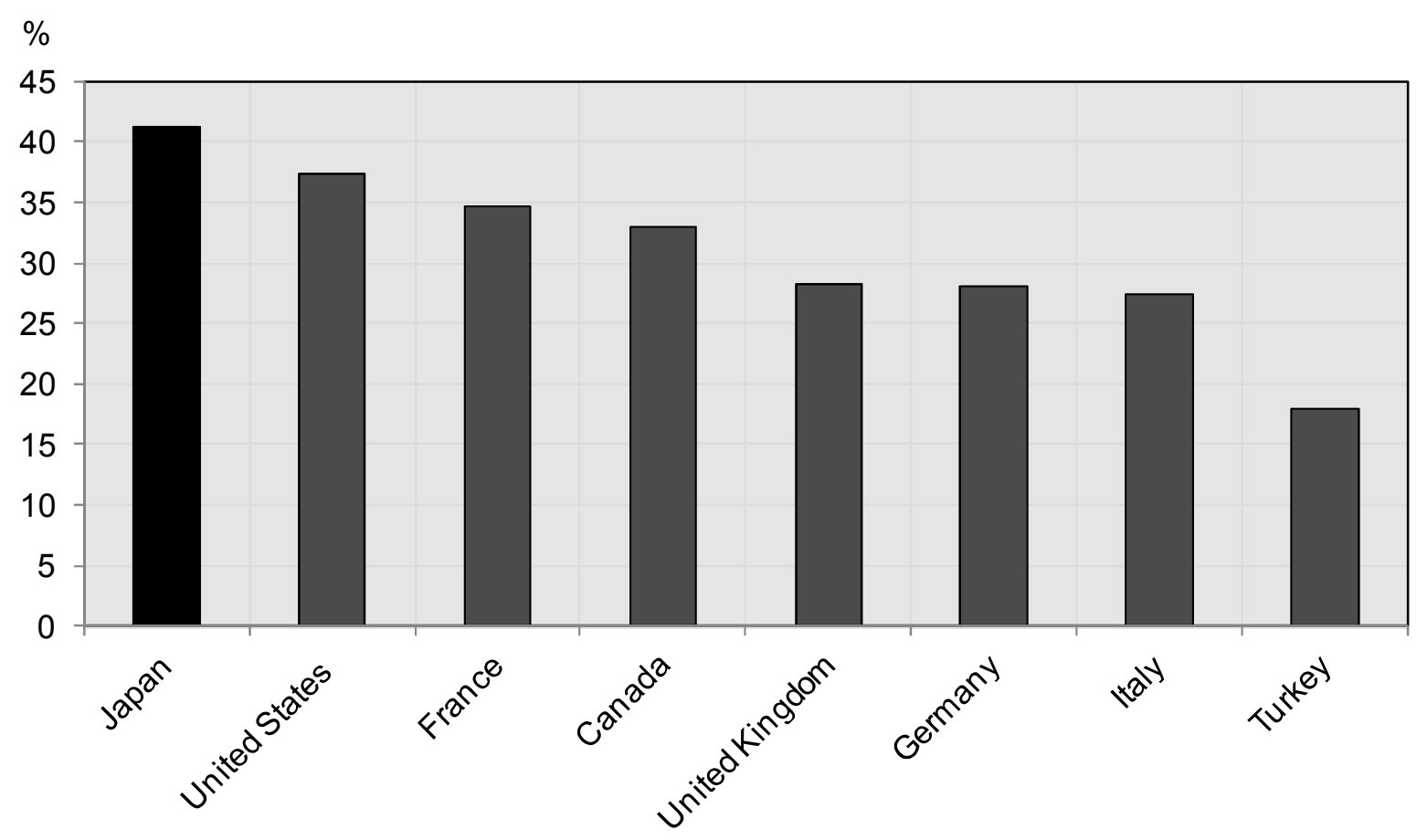

Source: ZEW (2009). 


\section{DSTI/DOC(2011)2}

The complexity of the tax system, and the resulting tax compliance costs for businesses, is another aspect that bears on FDI attraction. International investors look for certainty, predictability, consistency and timeliness in the application of tax rules, and in many cases these considerations are as important as the effective tax paid. Although a certain degree of complexity in the tax system is to be expected, the added expense incurred in understanding and complying with the tax system would tend to discourage foreign investors and make the business environment less friendly. Johansson et al. (2008) note that measuring the complexity of the tax system is not easy, and no representative cross-country tax indicator has been developed to that effect. Nevertheless, a cautious approach in the design of corporate taxation is to aim for a simple tax system.

\section{Policies to foster the internationalisation and openness of $R \& D$ and innovation}

International co-operation in innovation and $R \& D$ activities has become an important competitive factor for companies in recent years. MNEs in particular increasingly engage in international co-operative arrangements, such as cross-border strategic alliances (Dunning and Narula, 2004).

National science, technology and innovation (STI) policies increasingly need to account for these new forms of R\&D internationalisation. This is to ensure that the national economy benefits from the integration in international R\&D and innovation networks as well as in global value chains (GVCs). OECD (2006b) lists a number of policy considerations in regard to the internationalisation of R\&D and innovation:

- Economic fundamentals are important. Inward R\&D investment is closely related to policies that influence attractiveness for FDI in general. Factors such as political stability, public infrastructure, market size and development, tax rates and labour market conditions are decisive in decisions to locate R\&D.

- An adequate $R \& D$ policy for facing the challenge of internationalisation of $R \& D$ should not be designed in isolation from other policies. An effective R\&D policy implies co-ordination among various policy makers, linking R\&D with other policy areas, particularly research and technology development (RTD), innovation, education, economic affairs and foreign affairs.

- Measures to build an innovation-friendly environment and increase a country's scientific and technological capacities also help to attract foreign R\&D. A strong and vibrant academic and industrial research base, effective protection of intellectual property rights and a well-trained workforce are major determinants of MNE investment in R\&D but also promote the growth of domestic enterprises.

- The creation of a framework of local conditions that foster R\&D is crucial. Increasing the local $\mathrm{R} \& \mathrm{D}$ force can create the necessary absorptive capacity to profit from the presence of FDI in $\mathrm{R} \& \mathrm{D}$, to attract FDI in $\mathrm{R} \& \mathrm{D}$ and to foster international networking. The provision of a strong local infrastructure for business, in particular for R\&D is very important.

Fostering the internationalisation of R\&D and tapping into foreign sources of knowledge are at the core of several STI policy initiatives in OECD countries. These include: programmes for linking domestic firms to foreign sources of research and innovation; schemes for attracting foreign firms and FDI (such as R\&D tax incentives); initiatives supporting the internationalisation of domestic public research institutions (OECD, 2010f). 
DSTI/DOC(2011)2

Table 3. Internationalisation of knowledge: priority level and measures taken between 2008 and 2010

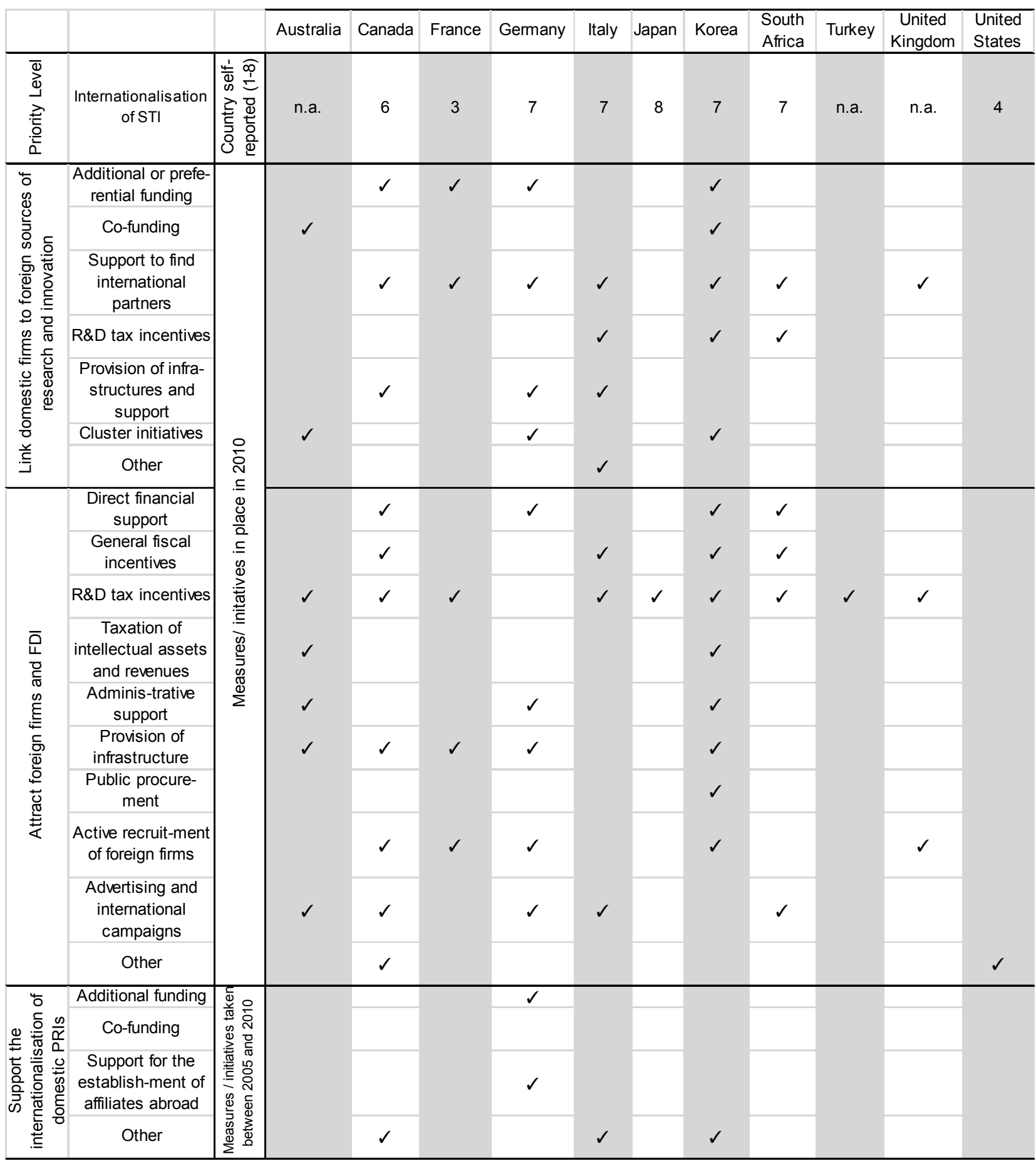

1. Self-reported ranking of national STI priorities based on a scale whereby $1=$ least important and $8=$ most important.

Source: OECD (2010f).

Levels of policy priority given to the internationalisation of national STI vary markedly from one country to the other (see Table 3 for an overview of OECD member countries that are also in the G20 and South Africa). Among the countries in this sample, Japan reports the highest level of importance to STI internationalisation. But policy priority does not necessarily translate into increased openness: the United 
States is an open and internationalised country although it reports a lower priority to STI internationalisation.

In spite of the strong policy priority placed on STI internationalisation, reportedly Japan did not introduce any significant measure to link domestic firms to foreign sources of research and innovation during 2010. In terms of attracting foreign firms and FDI (which is an indicator of the degree to which a country may benefit from knowledge spillovers and additional R\&D investment from multinationals), Japan recently introduced R\&D tax incentives, in line with many other G20 countries (see Box 5 for more details).

\section{Box 5. R\&D Tax incentives: rationale, measures and recent changes in Japan}

Tax incentives represent an important tool to foster R\&D. As of today more than 20 OECD governments provide fiscal incentives to support business R\&D, up from 12 in 1995 and 18 in 2004. One of the main rationales behind the use of fiscal incentives for R\&D is that they may contribute to sustaining national competitiveness. In a world where MNEs are increasingly internationalising their R\&D activities governments also compete in attracting R\&D activities of these corporations. Generous incentives through R\&D tax incentives can make a country a relatively more attractive location for R\&D investments than its competitors.

Governments may choose among various tools to foster business R\&D. They can offer direct support via grants or procurement or they can use fiscal incentives, such as R\&D tax incentives. For example, the United States rely more on direct support through competitive R\&D contracts, while Canada and Japan mostly use indirect support to foster industrial R\&D.

The OECD produced internationally comparable quantitative estimates of R\&D-related tax expenditures (i.e. forgone tax revenue) by central governments. While international comparisons are not perfect due to the heterogeneity of tax incentives and methods used in estimating them, this indicator shows that in each of the United States, Japan, Canada and Korea, forgone revenues as a result of tax incentives for R\&D amounted to more than USD 2 billion in 2008. More countries are now using tax incentives than a decade ago and the schemes are more generous than ever. Non-OECD G20 countries such as Brazil, China, India and South Africa also provide a generous and competitive tax environment for investment in R\&D.

In Japan, the government established a permanent volume-based credit of $8-10 \%$ (12\% for SMEs) in fiscal year 2003 for total R\&D expenditures within $20 \%$ of corporate income tax. In this system, firms are allowed to carry forward the unused portion of their R\&D tax credit only if they increase the amount of R\&D expenditures during the next fiscal year. In FY 2006, the government abolished a special depreciation of equipment for "developmental research". In FY 2008, the government modified its tax incentive system to allow firms to claim an additional credit $5 \%$ for the increase in R\&D expenditures or an additional credit $0.2 \%$ multiplied by the amount of $R \& D$ expenditures exceeding the equivalent of $10 \%$ of average sales, both within an additional $10 \%$ of corporate income tax. In FY 2009, the government, as a measure to address the economic crisis, temporarily increased the limitation of total tax credits up to $30 \%$ of corporate income tax for FY 2009 and 2010; and allowed firms to carry forward the exceeded tax credits in those fiscal years to 2012.

Source: OECD (2010b); OECD (2010f).

In order to make the most of globalised knowledge flows, countries need to foster co-operation across sectors, fields and borders. The development of STI platforms and open infrastructures is a key priority in this respect. Most countries give high priority to policies aiming to improve physical STI infrastructure and to link public research to industry and society. Both rank as top priorities for Japan, where collaboration in industry and science is weaker than in many other OECD countries (OECD, 2010f). In 2008-2010, Japan introduced measures to improve ICT networks, develop public-private partnerships (PPPs) and encourage public research diffusion. For example, the Innovation Network Corporation of Japan provides capital and managerial support to PPPs to next generation businesses in promising new technologies. 
Policies aimed at the development of clusters may help capitalise countries' strengths and thus increase the degree of openness of the national innovation system, as international and local firms may be attracted to specific activities and skills which exist in specific regions or locations (OECD, 2008c). In many OECD countries (including Japan), cluster initiatives are at the crossroad between STI policies on the one hand and industrial and enterprise policies on the other hand (OECD, 2007d). Recently Japan has begun a reform to foster regional activities and revitalise urban areas, in particular by supporting regional autonomy through the autonomous settlement regions and by expanding the physical infrastructure. Japan promotes the development of regional networks for business creation, co-operation for commercialisation and business matching with clusters in other regions (OECD, 2010f).

A transparent and enforceable intellectual property rights (IPRs) regime is important to ensure openness to international R\&D and innovation. Collaboration with foreign external partners can raise some issues regarding the protection of intangible assets and intellectual property (patents, trademarks, designs, trade secrets etc.). A survey of 300 senior executives identified potential theft of intellectual property as the most significant risk to developing global innovation networks (The Economist Intelligence Unit as reported in OECD, 2008c). Weak protection of IPRs undermines incentives to invest in innovation, facilitates counterfeiting and piracy, reduces the potential for technology transfer and limits the formation of markets for knowledge (OECD, 2011b). The risk of leakage of proprietary know-how to local competitors has traditionally favoured maintaining R\&D at home and encouraged investors to undertake projects abroad focusing on sales/distribution rather than R\&D (Javorcik, 2004). In addition, empirical studies on the impact of IPR protection on foreign investment in R\&D have found mixed results, but tend to show that IPR protection has a positive impact on inward R\&D (see for an overview OECD, 2008c).

One key issue for policy makers is to establish a system that provides rights to control use of an invention via IPR and diffuse knowledge about the invention (OECD, 2010f). Excessively strong IPR may hamper the appropriate use of protected knowledge and discourage follow-on research as well as research in adjacent areas (OECD, 2011b). Functioning knowledge networks and markets represent a means to trade and exchange knowledge within open networks of innovation, and may therefore facilitate the internationalisation of R\&D and innovation. As other OECD countries, Japan has recently introduced reforms in its IPR legislation, as well as specific IPR support towards SMEs.

Box 6 presents a case study of government strategies and programmes to support the internationalisation of R\&D and innovation in Sweden and Finland.

\section{Box 6. Internationalisation of R\&D and innovation: Sweden and Finland}

Governments are increasingly considering internationalisation and openness when designing national strategies and operational programmes in the fields of R\&D and innovation. In the OECD context, Sweden and Finland are good examples of countries that have integrated the need to promote the internationalisation of national actors in their programmes in support of innovation. Both are small, open and knowledge-intensive economies that face the challenge of integrating their national innovation systems in global networks. Their experience may provide useful lessons to countries that have larger markets for R\&D and innovation outcomes, and yet wish to reap the benefits from interacting with global networks of businesses and academia.

In Sweden, VINNOVA is a government agency under the Ministry of Enterprise, Energy and Communications whose main aim is to increase the competitiveness of Swedish researchers and companies. Every year VINNOVA invests EUR 220 million in new and ongoing projects, and the total value of projects amount to EUR 440 million thanks to co-financing. What distinguished VINNOVA from other government innovation agencies in OECD countries is a focused approach to redress systemic failures in national innovation systems. Another important feature of VINNOVA is the emphasis it places on promoting collaboration among different innovation actors, including companies, universities, research institutes and other organisations in the Swedish innovation system.

The need to promote the openness of Swedish R\&D and of the national innovation system has emerged as a result of several factors. Sweden is a small economy whose share in world R\&D is shrinking, but it also suffers 
from what has been named the "Swedish paradox", i.e. high expenditure in R\&D and innovation in the Swedish national innovation system not translating into commensurate innovation outcomes (Edquist, 2010).

VINNOVA has been playing an active role in promoting the internationalisation of Swedish R\&D and innovation through a dedicated strategy adopted in 2009 aiming at strengthening Swedish research and competitiveness through increased European and global co-operation (Boekholt et al., 2010). The internationalisation strategy involves (Schwaag-Serger, 2008):

- $\quad$ Strengthening the international dimension in the agency's operations (e.g. benchmarking and policy learning; internationalisation programmes).

- Increasing participation in the European Research Area .

- $\quad$ Running bilateral programmes with the United States, China, India and Japan.

- $\quad$ Building internationalisation competences (for example on research and innovation hubs and strategic emerging markets).

VINNOVA has also been one of the leading institutions in promoting the internationalisation of regional innovative clusters. For example, between 2002 and 2005 it managed the Visanu programme jointly with Nutek (Swedish Agency for Economic and Regional Growth) and Invest in Sweden Agency. As it was felt that Sweden had already made considerable investment in "hard" innovation infrastructure (such as universities and incubators), in the past, the programme was oriented more towards "soft" investment (OECD, 2007d). Visanu consisted of three main components: i) process support, to regional innovation systems and clusters chosen on the basis of their capabilities to increase international competitiveness; ii) knowledge development; and iii) international promotion to attract foreign investments and international competencies (Brundenius, Göransson and Ågren, 2008). Hence, fostering the inward and outward openness of regional innovation systems was a key driver of Visanu. The process of selecting the clusters that would participate in Visanu was also quite innovative: instead of being competitive, it was based on dialogue, requiring that clusters be well-established, clearly company managed and have the potential to be internationally competitive (OECD, 2007d). According to internal data collection, more than 1200 companies, mainly small or medium-sized, were part of the network activities of Visanu.

A similar focus on internationalisation may be found in programmes in support of innovation in Finland, in particular those of Sitra (The Finnish National Fund for Research and Development) and Tekes (The Finnish Funding Agency for Technology and Innovation). Sitra is a public organisation but acts independently from government control. According to Edquist, Luukkonen and Sotarauta (2009), Sitra has an important role of policy experimentation in the Finnish innovation system, by adding diversity to the system, and can help to avoid the risk of too one-sided ideas, policies and funding opportunities. Sitra's main objective is to promote Finland's economic growth, sustainable development as well as international competitiveness and co-operation. Sitra's programmes can have a thematic and/or geographic focus. In many cases, they aim at creating the enabling conditions for Finnish companies to integrate into global value chains and to increase Finland's attractiveness as an investment destination.

For example, the "Growth Programme for the Mechanical Industry 2008-2011" has aimed at promoting the establishment of three to five international system suppliers to the Finnish mechanical and metal products industries; providing information on models of collaboration between supplier companies and their customers and on the development of technologies in the global market; and promoting co-operation between Finnish and international companies in the mechanical and metal products industries. Examples of completed activities with a geographical focus include the "Russia Programme 2004-2007" and the "India Programme 2004-2008". Both programmes had among their objectives an increase in the collaboration between Finnish companies and companies based in Russia and India, respectively.

Tekes is the main organisation for the financing of R\&D and innovation in Finland and is implementing the Finnish National Innovation Strategy, which has a strong international focus. Every year, Tekes finances some 1 500 business research and development projects, and almost 600 public research projects at universities, research institutes and polytechnics. It grants around EUR 600 million towards innovative projects aimed at generating new know-how and new kinds of products, processes, and service or business concepts. In regard to Tekes' international activities, Asia has been of the most important area of focus for the agency. In particular, Tekes has promoted science and technology co-operation with Chinese and Japanese partners, as well as activities with India and Singapore (Tekes, 2010). The agency has offices in China, Japan and the United States. 
In addition, Tekes contributes to building global networks of innovation actors as part of the FinNode Innovation Centre network. FinNode is a community of Finnish public and non-profit organisations to boost international R\&D co-operation and business and operates in China, Japan, Russia and the United States. According to its website, FinNode is an "access node to hook up with partners in Finland - whether [...] business contacts, cutting-edge research or R\&D resources". In addition to Tekes, other partners involved in the network include the Academy of Finland, FinPro (organisation promoting the internationalisation of Finnish firms), the Ministry of Foreign Affairs, and VTT (the Technical Research Centre of Finland). FinNode is steered by the Ministry of Employment and the Economy.

The establishment of Aalto University in 2010 has been considered one of the best examples of Finland's large scale, holistic approach to innovation (Kao, 2009). This institution was created from the merger of three existing universities: the Helsinki's School of Economics, the University of Art and Design, and the University of Technology. The latter school was then divided into four new schools as of 1 January 2011. The university's endowments are mainly made up of private donations and funding from the Finnish government, with total capital expected to reach EUR 700 million during 2011. Among others, Tekes provides financing for a number of research projects.

Aalto University adopts an open approach to innovation, based on a multidisciplinary collaborative environment allowing research groups, enterprises and public bodies to work together. The university brings together experts from different fields (e.g. design, media, technology...), a model of collaboration based on the idea that innovation comes from cross-disciplinary efforts (Kao, 2009). The university is increasingly engaging in collaboration with international networks of research institutes and businesses.

\section{Labour market policies}

The link between labour market regulations and economic openness can be observed especially in its link to attracting foreign capital. A survey of FDI determinants of MNEs with production operations located in the UK shows that labour market flexibility was identified as representing a moderate or high degree of importance. $61.4 \%$ of all respondents identified labour market flexibility as a "very important" or "vitally important" determinant of FDI, although this was identified as second-level factor (Whyman and Baimbridge, 2006). In addition, Hajkova et al. (2006) found a robust and statistically significant impact of strict labour market policies on FDI, with expected negative signs. In their model, labour market policies are captured by two indicators: tax wedges on labour income and the OECD indicator of employment protection legislation (EPL).

Tax wedges on labour represent the difference between what the employers pay out in wages and social security charges and what employees take home after tax and social security deductions. They may represent an important obstacle to job creation and people's willingness to work. Figure 14 shows an overview of average tax wedges across OECD countries that are also in the G20. At 29.3\% in 2009, Japan's tax wedge is well below the values of large EU countries and OECD average and on par with the United States. This suggests a relatively positive contribution of labour taxation to the country's openness to foreign capital. 
Figure 14. Average Tax Wedge, 2009

Single person at $100 \%$ of average earnings, no child

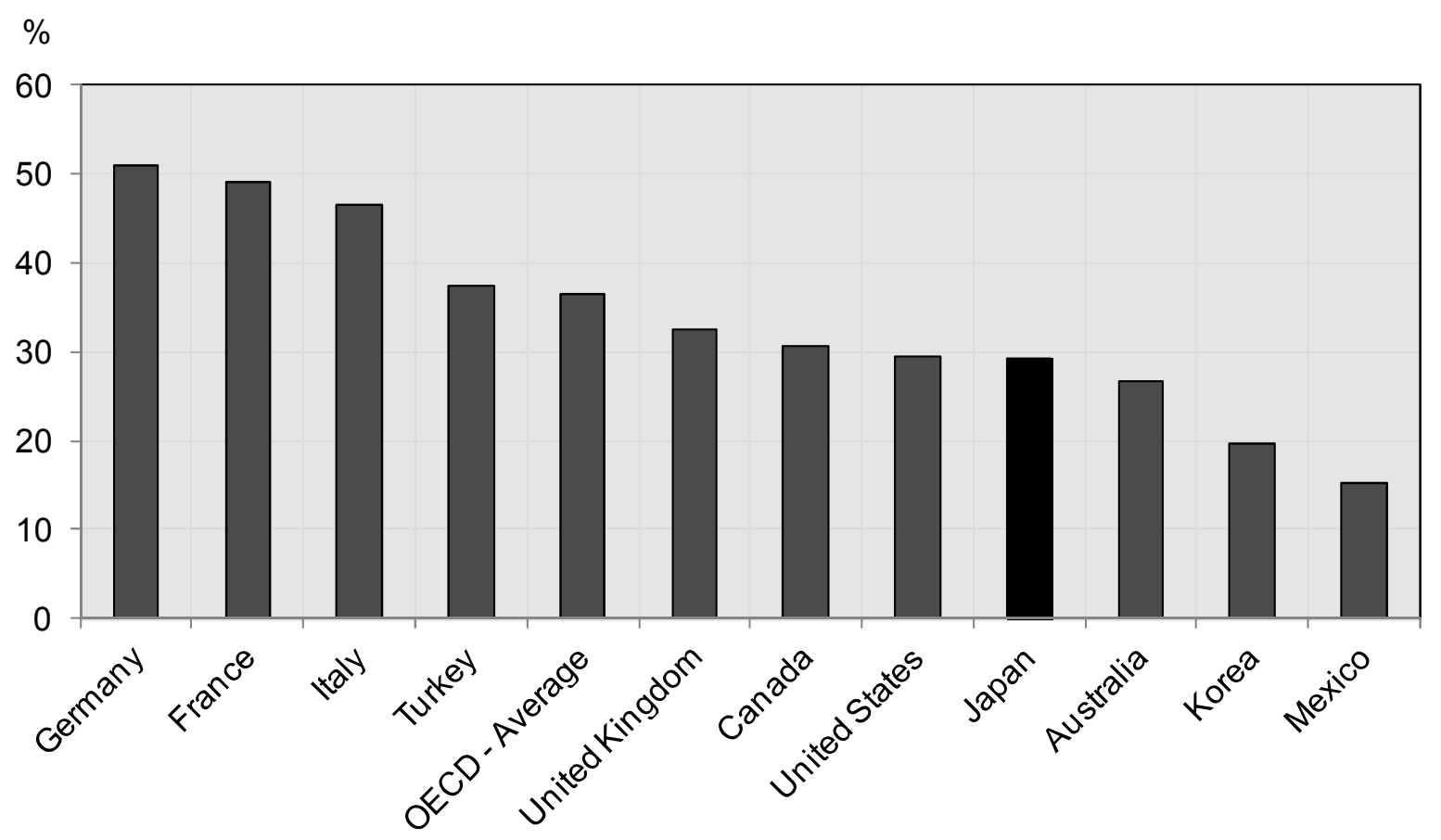

Source: OECD (2010g).

Employment protection legislation (EPL) includes the restrictions imposed on firms when hiring and firing workers. Strict EPL has an ambiguous effect on total unemployment: it reduces job destruction on the one hand, but it may also result in lower job creation on the other hand. Overall, a high level of EPL is expected to have negative effects on the labour market. For example, it may result in reducing productivity and innovation. Bassanini and Venn (2007) find that strict statutory employment protection for regular contracts appears to dampen productivity growth, most likely by restricting the movement of labour into emerging, high-productivity activities, firms or industries.

Figure 15 presents an overview of the OECD indicators of employment protection for all G20 countries, except for Argentina and Saudi Arabia for which comparable data is not available. These indicators measure the procedures and costs involved in dismissing individuals or groups of workers and the procedures involved in hiring workers on fixed-term or temporary work agency contracts. The level of employment protection in Japan is relatively low and below the OECD average. 
Figure 15. Employment protection in selected G20 countries, 2008

Scale from 0 (least stringent) to 6 (most stringent)

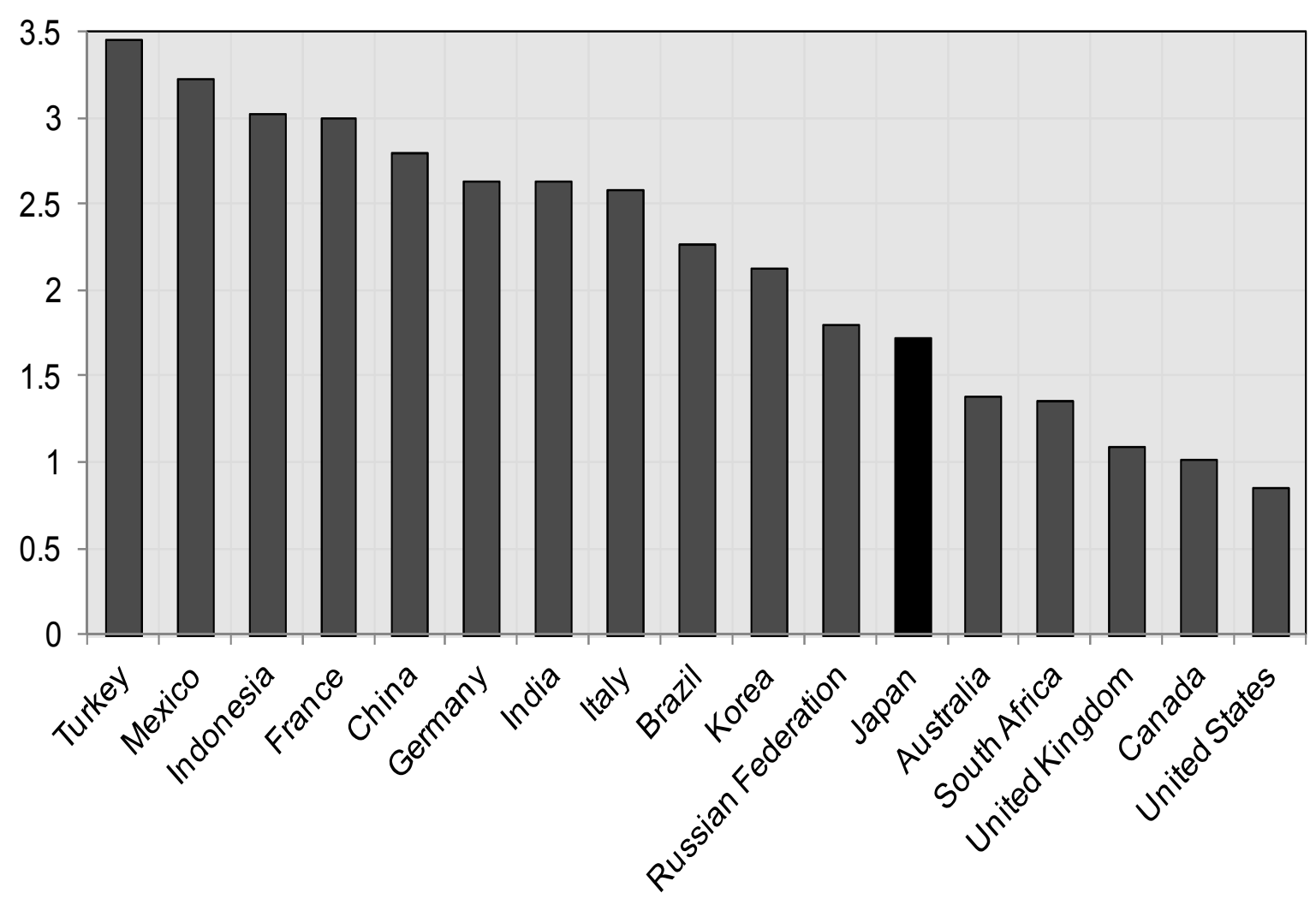

Source: OECD Indicators on employment protection.

Box 7 presents a case study of labour market reforms in support of economic openness in Germany.

\section{Box 7. Increased openness through labour market reforms: Germany}

After a period of economic difficulties following the reunification of the Western and Eastern parts of the country, the economy of Germany rebounded strongly in the 2000 s and managed to weather remarkably well the financial and economic crisis. Among other factors, labour market reforms introduced under the so-called "Agenda 2010" have been credited as playing a role in maintaining an open economy, attracting investment and sustaining exports.

Political reunification in 1990 had a major impact on Germany's economy, both by acting as a drag on its performance and by worsening pre-existing structural deficiencies. Higher wages and inflation reduced Germany's international competitiveness and its export performance. In addition, massive fiscal transfers linked to reconstruction and fiscal support in the Eastern part of the country contributed to a deterioration of public finances. During the 1990s, Germany's economic performance was somewhat sluggish, with GDP growth below the OECD level and high unemployment rates. In addition, total economy unit labour costs remained high (although stable) throughout the decade (see Figures below). 
DSTI/DOC(2011)2

GDP growth, Germany and OECD, 1990-2009

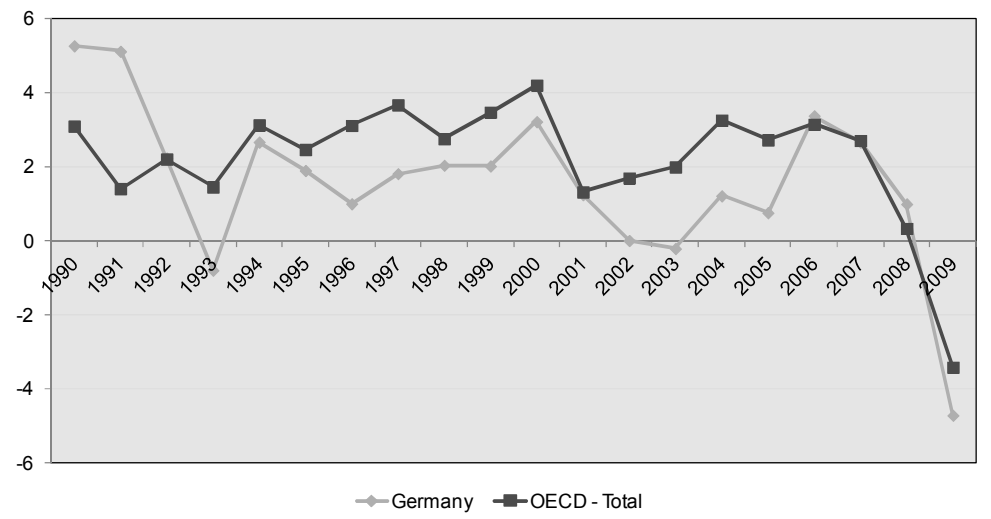

Source: National Accounts of OECD countries, Main Aggregates.

Annual Harmonised Unemployment Rate (HUR), 1991-2010

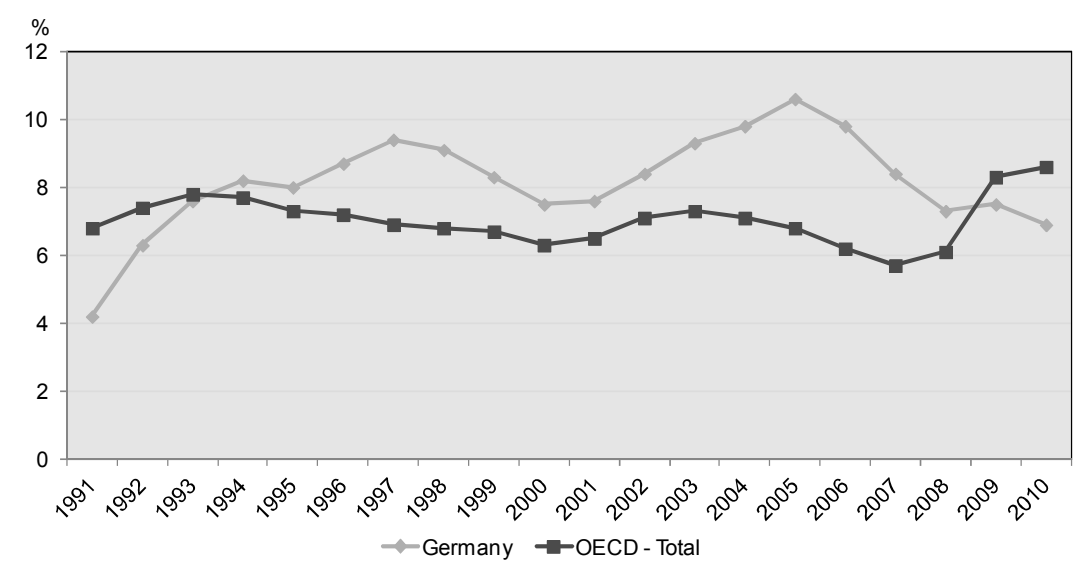

Source: OECD Labour Force Statistics (Main Economic Indicators).

Unit Labour Costs, Total Economy

Index OECD base year $(2005=100)$

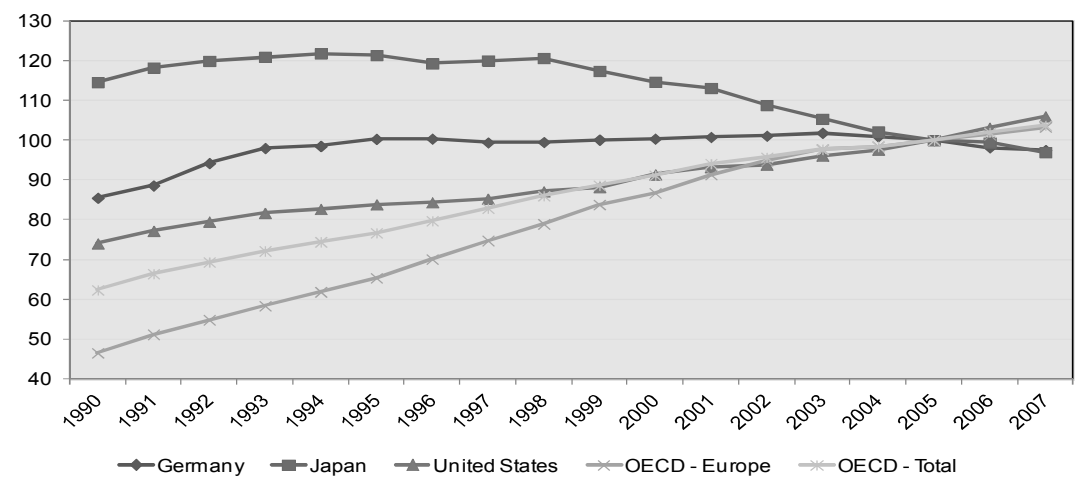

Source: OECD Main Economic Indicators.

78 
In this environment, during 2003-2005 the government implemented the "Agenda 2010" reform programme, aimed at tackling the reputed causes of Germany's economic stagnation through labour market, social security and taxation reforms. In particular, the following labour market reforms were introduced on the labour supply side (the Hartz laws):

- Improve integration of job seekers by creating new opportunities for temporary work, self-employment and employment in households, and new job contracts with lower social security contributions (Hartz III, 2003).

- $\quad$ Turn the Federal Employment Agency into a modern service provider, with responsibility for managing unemployment benefits and finding placements for jobless (Hartz III, 2004).

- Increase the employment prospects and work incentives for welfare recipients, by merging the former unemployment assistance (granted to former recipients of unemployment benefits who had exhausted their unemployment insurance benefit claim) and the former social assistance (paid to individuals not eligible for the unemployment assistance) to form the so-called unemployment benefit II (Hartz IV, 2005).

In 2006, a significant cut in unemployment benefit duration for long-term unemployed older workers was introduced, although in 2007 it was decided to lengthen the benefit duration again somewhat, while simultaneously intensifying activation of older workers. In addition, in 2007 it was decided that the retirement age would be gradually increased to 67 years until 2029 starting in 2012 with persons born in the year 1947 or later.

These structural reforms appear to have yielded significant benefits to the Germany economy and contributed to restoring its competitiveness. Before the economic crisis, the Hartz reforms contributed to an increase in labour utilisation. GDP growth picked up in 2006 and unemployment rates steadily decreased until falling below the OECD average in 2009. To some extent the reforms may also explain why during the recent economic crisis, the increase in the unemployment rate was below the OECD average (although the fall in German GDP was above average). The reduction in the generosity of unemployment benefits and the shortening of the duration of unemployment insurance benefit payments are estimated to have lowered the non-accelerating inflation rate of unemployment (NAIRU) by around $1 / 2$ percentage point. This effect may have been spread over several years and therefore have countered some of the adverse impacts of the crisis by lowering structural unemployment. ${ }^{1}$

Agenda 2010 may also partly explain Germany's export strength of recent years. By exerting restraints on wages, reforms contributed to keep unit labour costs in check, thus promoting the country's international competitiveness. ${ }^{2}$ In 2008 , the level of real wages (deflated with the GDP deflator) was virtually the same as in 2001.

Notes:

1. An inward movement of the Beveridge curve between January 2008 and January 2009 points to increased efficiency of the labour market through an improvement of the matching process. However, other factors played a decisive role in tempering the unemployment effects of the crisis: for examples hours worked have been reduced significantly.

2. However, Marin (2010) observes that the lowering of Germany's relative unit labour costs also owes greatly to offshoring and/or outsourcing part of the production to the new EU member states in Eastern Europe, Russia and Ukraine.

Source: This case study draws on OECD (2010h); OECD (2008f); OECD (2006c); OECD (2004); Schneider and Zimmermann (2010); The Economist (2010); European Commission (2008); Deutsche Welle (2003).

\section{Policies to encourage skilled labour migration and mobility}

Migration can play an important role in sustaining long term economic growth in OECD countries, and overly restrictive immigration laws may prevent significant gains for the host economy from materialising. Long-term demographic trends provide the most compelling argument in this regard. OECD (2010i) forecasts that if migration rates stay at their current levels, the working age population in OECD countries will rise by $1.9 \%$ between 2010 and 2020, compared to $8.6 \%$ growth between 2000 and 2010 . Economic benefits of migration include: integration into international networks, increase in entrepreneurial activity, and improved integration of both sending and receiving countries into the international division of labour, among others (Huber et al., 2010). 
In the economic literature, the impacts of migration on the receiving country has been analysed along a number of different dimensions, including: immigrant assimilation in the labour market; displacement effects in the labour market; immigration and public finances (Kerr and Kerr, 2011). Contrary to conventional wisdom, most empirical studies found that immigration does not have significant negative impacts on native wages or employment. ${ }^{27}$ Some studies even found positive effects: for example, Ottaviano and Peri (2005) find that immigration in the United States during the 1990s had a sizeable beneficial effect on the wages of United States-born workers. Also going against the popular belief that immigrants may represent a large fiscal burden for the receiving country, most empirical analyses found net positive effects of immigration on public finances. In any case, these effects are found to be small, be they positive or negative. In Rowthorn (2008), estimates of the net fiscal contribution of immigration normally lie within the range of $\pm 1 \%$ of GDP.

A recent survey of business executives by the IMD Business School for the World Competitiveness Yearbook ranks Japan as one of the G20 countries where immigration laws prevent companies from employing foreign labour (Figure 16). This suggests that Japan may not be reaping fully the potential benefits deriving from tapping into sources of foreign labour.

\section{Figure 16. Immigration laws preventing companies from employing foreign labour}

Immigration laws do not prevent your company from employing foreign labour

IMD WCY Executive Survey based on an index from 0 to 10

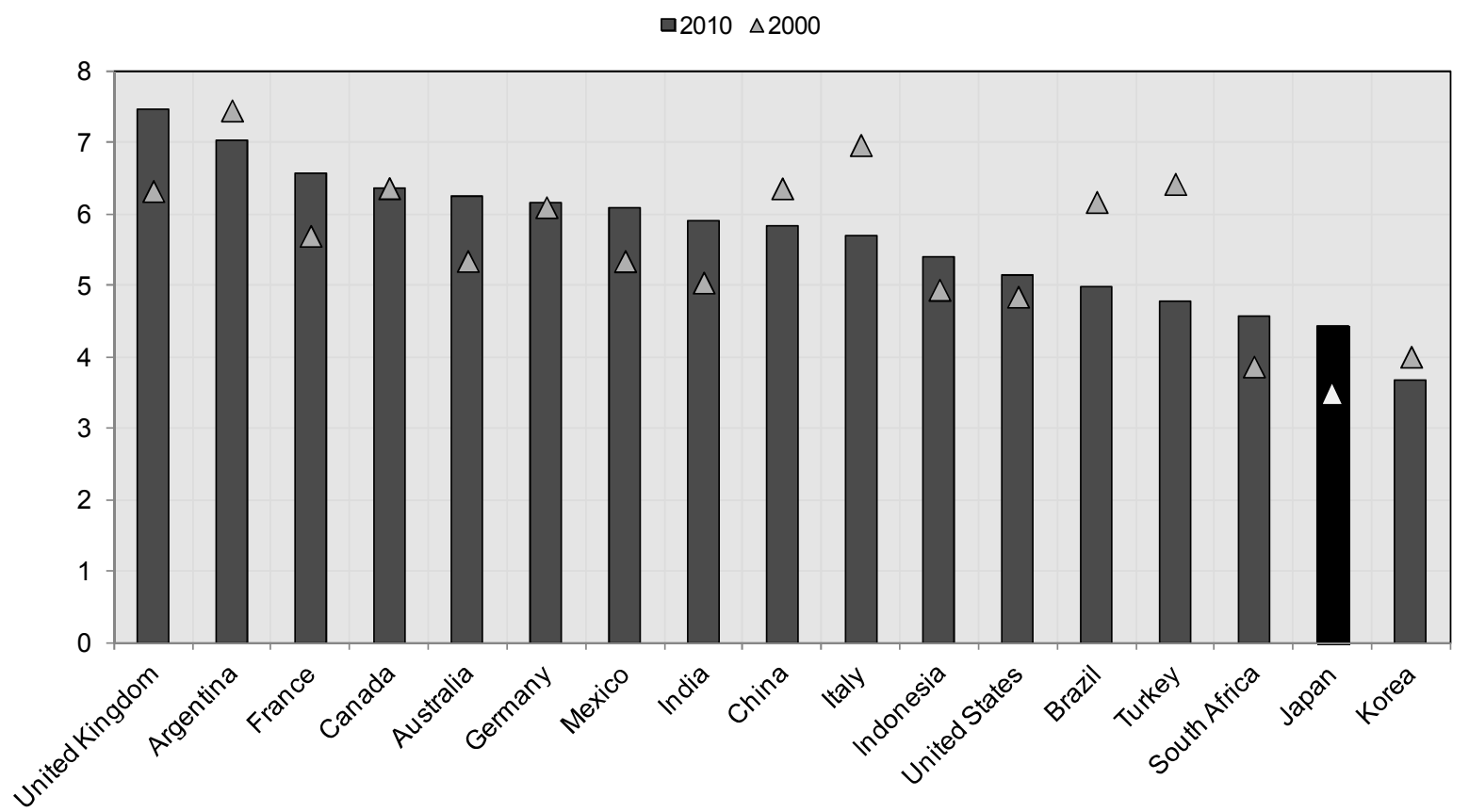

Source: IMD World Competitiveness Yearbook, Updated May 2010

Ensuring international mobility of workers is a priority in most OECD and non-OECD countries, and several governments have implemented policies both to retain and attract human resources in science \& technology (HRST) and to accompany national talent out and back. One reason driving these policies is that many countries, especially in the OECD, are expected to experience significant skills shortages of highly-skilled labour in the coming years. Fostering immigration is seen by many as a way to address this challenge. In addition, policy makers in OECD countries are increasingly focusing on selective migration 
policies, as competition to attract and retain highly qualified workers among OECD and perhaps nonOECD countries intensifies (Chaloff and Lemaitre, 2009).

In OECD countries, policies to facilitate the migration of highly skilled workers fall into two main categories: demand-driven systems of recruitment (through employer requests); and supply-driven systems (by inviting candidates to apply and selecting them on the basis of certain characteristics, for which points are assigned). In Japan (as in most European countries and Korea), migration of the highly skilled is mostly driven by employers, hence a foreign highly skilled worker needs to be offered a job before he can enter the country to work (Chaloff and Lemaittre, 2009).

Countries may also offer special migration schemes for highly skilled workers. For example, international students may be allowed to work during their studies, or remain in the host country as foreign workers after having graduated. In Japan and most European countries, students must find a job related to their field of study (with preference given to scientific or technical skills) after graduation before they can be considered for immigration. Another targeted way to encourage inflows of foreign workers with relatively limited constraints is through intra-corporate transfers within multinational firms, which may be facilitated by special government schemes. For example, Japan grants renewable permits for one or three years. Chaloff and Lemaitre (2009) note that in the case of Japan, such intra-company transfers are an important channel for inflows of highly skilled workers in an otherwise closed labour market: in 2006, there were more than 14000 of such expatriates working in Japan. By comparison, in the same year inflows of foreign workers amounted to 81374 people, and the total stock of foreign labour to 178761 people. $^{28}$

OECD (2008d) reviews OECD country's strategies regarding the mobility of HRST, and finds that Japan and the United Kingdom have the most formalised mobility strategies. These include government policies and programmes to encourage the inward and outward international mobility of HRST, including doctoral holders, doctoral students and researchers, but also mobility websites and diaspora strategies. Table 4 shows an overview of those strategies for selected OECD countries, the European Commission and South Africa. Although Japan did have an explicit mobility strategy, it lacked specific tools such as a website or a programme to exploit the potential of the diaspora to act as a channel of knowledge flows to the home country.

Mobility strategies translate into operational programmes, which vary significantly in intensity and breadth across OECD countries. While some countries focused on one or few areas with a wide range of programmes, others adopted a broader approach with varying numbers of incentives (OECD, 2008d). Relative to the other countries in the sample, Japan offered a high number of incentives across a very broad range of programmes.

Table 5 shows immigration policies targeted at facilitating inflows of HRST for selected OECD countries, South Africa and the European Commission, in addition to measures implemented in the framework of general high-skill migration policies. Japan is among the countries providing facilitated immigration procedures for HRST, together with Canada and the United Kingdom. It also offers multipleentry visas, which ensures ease of return and circularity of HRST workers. In addition, fostering global talents and increasing acceptance of highly-skilled personnel is one of the key objectives of the "New Growth Strategy" adopted by the government in 2010. In particular, Japan is considering the adoption of a "points-based system", in which the country's authorities evaluate the suitability of migrants on the basis of certain criteria. This system has been adopted in the United Kingdom, Canada, Australia, New Zealand and Denmark. 
DSTI/DOC(2011)2

Table 4. Mobility strategies

\begin{tabular}{|c|c|c|c|}
\hline & $\begin{array}{c}\text { Strategy to encourage mobility of } \\
\text { HRST }\end{array}$ & $\begin{array}{l}\text { Webpage or organisation providing } \\
\text { information to inflows of HRST }\end{array}$ & Diaspora strategy \\
\hline Australia & $\begin{array}{l}\text { Initiatives in place to promote } \\
\text { international research collaboration, } \\
\text { including mobility of researchers. }\end{array}$ & $\begin{array}{l}\text { Mobility portal established in } \\
\text { conjunction with FEAST (Forum for } \\
\text { European-Australian S\&T } \\
\text { Cooperation) - www.mobility.org.au }\end{array}$ & \\
\hline Canada & $\begin{array}{l}\text { Mobility is central to a national } \\
\text { strategy to make Canada one of the } \\
\text { world's top countries for R\&D and to } \\
\text { build an innovative and competitive } \\
\text { economy. }\end{array}$ & & \\
\hline Japan & $\begin{array}{l}\text { Yes - "Strategic Promotion of the } \\
\text { International Activity of Science and } \\
\text { Technology" - Ministry of Education, } \\
\text { Culture, Sports, Science and } \\
\text { Technology (MEXT). High priority on } \\
\text { strengthening collaboration with } \\
\text { Asian countries and } \\
\text { internationalising universities. }\end{array}$ & & \\
\hline Korea & $\begin{array}{l}\text { Enhancing international mobility of } \\
\text { researchers in two categories: } \\
\text { Korean natives who go abroad for } \\
\text { study and research; and the inflow } \\
\text { of foreign researchers. }\end{array}$ & $\begin{array}{l}\text { No central website, but individual } \\
\text { websites for each programme. }\end{array}$ & $\begin{array}{l}\text { Web portal has been established } \\
\text { for knowledge exchange among } \\
\text { Korean researchers worldwide. } \\
\text { Also distinguished scientists } \\
\text { residing abroad are invited to visit } \\
\text { Korea and establish networks with } \\
\text { domestic researchers. }\end{array}$ \\
\hline South Africa & $\begin{array}{l}\text { Various mechanisms exist to } \\
\text { encourage inward and outward } \\
\text { mobility of researchers, doctoral } \\
\text { students and HRST, mostly } \\
\text { managed by the National Research } \\
\text { Foundation (NRF). }\end{array}$ & $\begin{array}{l}\text { NRF website (particularly the link to } \\
\text { the South African Research Chairs } \\
\text { Initiative) provides information on } \\
\text { inflows of HRST } \\
\text { (www.nrf.ac.za/sarchi/). }\end{array}$ & $\begin{array}{l}\text { Platforms such as the African } \\
\text { Union - African Diaspora } \\
\text { Ministerial Conferences are used. } \\
\text { Also, the Department of Science } \\
\text { and Technology holds "South } \\
\text { Africa Days" in several } \\
\text { destinations abroad where there } \\
\text { is South African talent. }\end{array}$ \\
\hline United Kingdom & $\begin{array}{l}\text { Yes. International mobility of } \\
\text { students and researchers is } \\
\text { embedded in "A Strategy for } \\
\text { International Engagement in } \\
\text { Research and Development", } \\
\text { published by the Global Science } \\
\text { and Innovation Forum (GSIF). See } \\
\text { www.berr.gov.uk/files/file34726.pdf. }\end{array}$ & $\begin{array}{l}\text { Yes. Primary site is Network UK- } \\
\text { the researcher's mobility portal } \\
\text { (www.britishcouncil.org/eumobility). }\end{array}$ & $\begin{array}{l}\text { The GSIF Strategy for International } \\
\text { Engagement in Research and } \\
\text { Development recognises that the } \\
\text { United Kingdom should } \\
\text { encourage and promote an } \\
\text { alumni network of researchers } \\
\text { who have been working in the } \\
\text { United Kingdom. A new } \\
\text { International Fellowships } \\
\text { Scheme, with linked alumni } \\
\text { engagement and operated in } \\
\text { partnership by the Royal Society, } \\
\text { British Academy, Royal Academy } \\
\text { of Engineering and Research } \\
\text { Councils UK, was launched in } \\
2008 / 09 \text {. }\end{array}$ \\
\hline $\begin{array}{l}\text { European } \\
\text { Commission }\end{array}$ & $\begin{array}{l}\text { Yes. See European Commission } \\
\text { COM(2001)331 (20/6/2001). Aim of } \\
\text { strategy is to develop an open, trans- } \\
\text { European labour market for } \\
\text { researchers. }\end{array}$ & $\begin{array}{l}\text { Yes. Primary site is the European } \\
\text { Researcher's Mobility Portal. }\end{array}$ & $\begin{array}{l}\text { The European Commission has } \\
\text { proposed to network all EU } \\
\text { researchers working abroad, } \\
\text { beginning with the United States } \\
\text { (http://cordis.europa.eu/eralink/), } \\
\text { followed by other countries, such } \\
\text { as Japan. }\end{array}$ \\
\hline
\end{tabular}

1. From June 2008, the principal website is the EURAXESS portal (http://ec.europa.eu/eracareers/index_en.cfm).

Source: OECD (2008d), based on OECD Questionnaire on the International Mobility of Researchers (2007); Pilot Questionnaire (2006) for Australia, Canada and South Africa. 
Table 5. Immigration to facilitate policy inflows of HRST

\begin{tabular}{|c|c|c|c|}
\hline & $\begin{array}{c}\text { Facilitated procedures } \\
\text { for HRST }\end{array}$ & Special visas for HRST & $\begin{array}{c}\text { General highly skilled } \\
\text { migration policy }\end{array}$ \\
\hline Australia & & $\begin{array}{c}\text { Yes - Business Long-Stay } \\
\text { visa, Educational visa, } \\
\text { Visiting Academic visa. }\end{array}$ & Yes \\
\hline Canada & $\begin{array}{l}\text { Yes - Canada Chairs } \\
\text { applicants exempt from } \\
\text { Labour Market Opinion } \\
\text { requirement. }\end{array}$ & $\begin{array}{c}\text { Yes - Off-campus Work } \\
\text { Permit }\end{array}$ & Yes \\
\hline Japan & Yes & Multiple-entry visa available & \\
\hline Korea & & $\begin{array}{c}\text { Yes - Science Card, IT Card, } \\
\text { Gold Card }\end{array}$ & \\
\hline South Africa & & $\begin{array}{l}2002 \text { Immigration Act } \\
\text { provides for work permits for } \\
\text { foreign experts }\end{array}$ & \\
\hline United Kingdom & $\begin{array}{c}\text { Yes - no work permit } \\
\text { requirements for certain } \\
\text { students. }\end{array}$ & $\begin{array}{c}\text { Sponsored Researcher work } \\
\text { permit category for non-EEA } \\
\text { nationals }\end{array}$ & Yes \\
\hline European Commission & & $\begin{array}{l}\text { Scientific Visa (EC Directive } \\
2005 / 71)\end{array}$ & \\
\hline
\end{tabular}

Source: OECD (2008d), based on OECD Questionnaire on the International Mobility of Researchers (2007). Pilot Questionnaire (2006-2007) for Australia, Canada and South Africa.

As noted by Chaloff and Lemaitre (2009), it is not sufficient to allow and facilitate the immigration of highly-skilled workers, as these people must also want to settle and work in the immigration country. The following factors may have a bearing on the mobility of the highly-skilled: wage levels, quality of life, existing communities, languages, likelihood of extension of permanent residency, and access to labour market of family members. According to the perception of company executives interviewed by the IMD for the World Competitiveness Yearbook, Japan's business environment does not score very high in terms of attracting foreign highly-skilled people (Figure 17). 
Figure 17. Business environment is attractive to foreign highly-skilled people

Foreign high-skilled people are attracted to your country's business environment

IMD WCY executive survey based on an index from 0 to 10

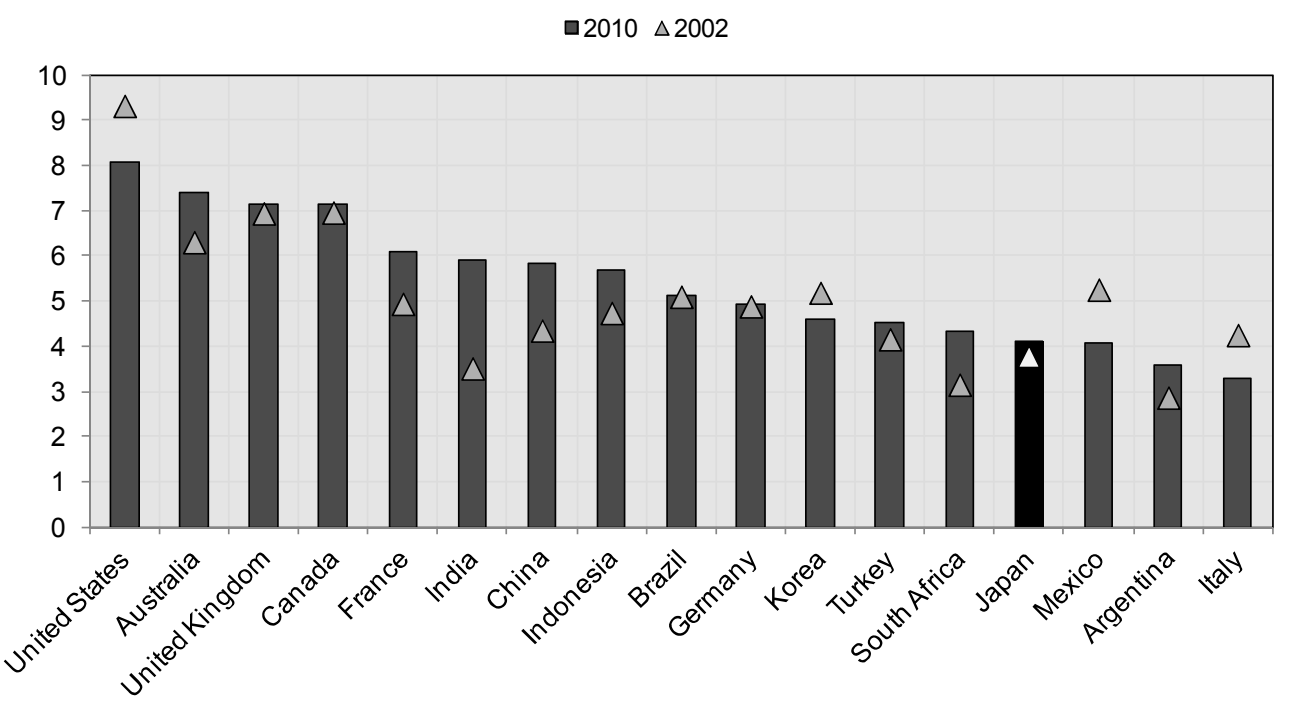

Source: IMD World Competitiveness Yearbook, Updated: MAY 2010.

While some of the factors listed above are not easily influenced by public policy, there is still a role for governments to increase country attractiveness for immigration of the highly-skilled, for example through social and cultural support. Table 6 provides some examples of such social and cultural support programmes offered to facilitate inflows of HRST. Like several other countries, Japan provides nontargeted assistance, helping migrants in general with support offered by non-governmental organisations (NGOs), community organisations, educational institutions and government agencies.

Table 6. Social and cultural support to facilitate inflows of HRST

\begin{tabular}{|c|c|c|c|}
\hline & Service providers & Web information & Non-targeted assistance \\
\hline Aus tralia & & & Yes \\
\hline Japan & & & $\begin{array}{l}\text { Yes - via Strategic Fund for } \\
\text { Establishing International } \\
\text { Headquarters in Universities }\end{array}$ \\
\hline \multicolumn{4}{|l|}{ Korea } \\
\hline South Africa & & & Yes \\
\hline United Kingdom & $\begin{array}{l}\text { Yes - } 12 \text { mobility } \\
\text { centres }\end{array}$ & $\begin{array}{c}\text { wuw. britishcouncil.org/ } \\
\text { eumobility }\end{array}$ & \\
\hline $\begin{array}{l}\text { European } \\
\text { Commission }\end{array}$ & $\begin{array}{c}\text { European Network of } \\
\text { Mobility Centres ( } 200 \\
\text { centres in } 32 \text { countries) }\end{array}$ & $\begin{array}{l}\text { Central portal } \\
\text { http://ec.europa.eu/erac } \\
\text { areers/index_en.cfm }\end{array}$ & \\
\hline
\end{tabular}

Source: OECD (2008d) based on OECD Questionnaire on the International Mobility of Researchers (2007). Pilot Questionnaire (2006) for Australia, Canada and South Africa

In terms of outward openness, the benefits of a vast diaspora with strong links with the sending country are well known. The existence of social and other links increases mutual trust and along with it the 
probability that knowledge will continue to flow back to the home country, facilitating co-operation in science and trade exchanges.

Japan has a long tradition of emigration, but the resulting Japanese diaspora is relatively small. The exact number of "Nikkeijin" (i.e. Japanese nationals or non-nationals of Japanese descendence living overseas) are not known with precision, as Japanese authorities are only concerned with collecting statistics about Japanese nationals. However, in its 2005 "Annual Report on Statistics on Japanese Nationals Overseas", the Ministry of Foreign Affairs of Japan estimates a total number of 2.6 million Nikkeijin. By comparison, there are an estimated 25 million non-resident Indians and 60 million overseas Chinese, including significant numbers in nearly all countries (The Economist, 2011).

Conventional wisdom holds that the transfer of highly educated people from one country to another (commonly referred to as "brain drain") will lead to a loss of productive and innovative capacity of the sending country. More recently, "brain circulation" has attracted policy attention since the temporary and circulation migration between home and abroad may be beneficial to the sending countries. Individuals may transfer the knowledge they acquire to their home country and maintain networks abroad; they often return to the home country after a period abroad and will likewise transfer knowledge. In order to maximise the benefits from brain circulation, countries need to implement policies that ensure sufficient absorptive capacity. In particular, returning highly skilled professionals should be able to integrate in the local labour market at a level that is appropriate for their skills and knowledge (OECD, 2008d).

In addition, as shown in Chapter 1, Figure F.1 Japan has one of the lowest emigration rates among G20 countries, both total emigration and emigration of the tertiary educated. This means that Japan may be missing out on the significant benefits that brain circulation and outward migration have on the sending country.

Because of the importance of brain circulation and the positive spillovers that outflows of highlyskilled human resources may generate for the economy of the sending country, several governments have designed and implemented policies to encourage research abroad. Such programmes include grants and scholarships, fellowships, travel and living support, exchange programmes and other mechanisms. They are shown in Table 7 for a selection of OECD countries, South Africa and the European Commission. Japan implemented quite a broad range of measures, although with a relatively lower number of programmes relative to other countries. In addition, since 2008 Japan has provided funding for scholarship and grants aimed at researchers. It has also introduced programmes to encourage return migration and thus brain circulation (OECD, 2010f).

Table 7. Policies to facilitate research abroad (outflows of HRST)

\begin{tabular}{|c|c|c|c|c|c|}
\hline & $\begin{array}{l}\text { Research grants } \\
\text { and scholarships }\end{array}$ & Fellowships & $\begin{array}{c}\text { Travel and } \\
\text { living support }\end{array}$ & $\begin{array}{l}\text { Exchange } \\
\text { programmes }\end{array}$ & Other \\
\hline Australia & $\checkmark \checkmark \checkmark$ & $\begin{array}{l}\checkmark \checkmark \checkmark \checkmark \checkmark \\
\checkmark \checkmark\end{array}$ & & & $\checkmark$ \\
\hline Canada & $\checkmark \checkmark \checkmark$ & $\checkmark \checkmark$ & & & $\checkmark$ \\
\hline Japan & $\checkmark$ & $\checkmark$ & & $\checkmark$ & $\checkmark$ \\
\hline Korea & $\checkmark \checkmark \checkmark$ & & $\checkmark \checkmark$ & $\checkmark$ & \\
\hline $\begin{array}{l}\text { South } \\
\text { Africa }\end{array}$ & $\checkmark$ & $\checkmark$ & $\checkmark \checkmark \checkmark \checkmark$ & & \\
\hline $\begin{array}{l}\text { United } \\
\text { Kingdom }\end{array}$ & $\checkmark \checkmark \checkmark \checkmark \checkmark$ & $\checkmark$ & $\checkmark \checkmark \checkmark$ & $\checkmark$ & $\checkmark \checkmark \checkmark \checkmark \checkmark$ \\
\hline
\end{tabular}

1. $\checkmark=$ number of programmes offering this type of support.

Source: OECD (2008d) based on OECD Questionnaire on the International Mobility of Researchers (2007). Pilot Questionnaire (2006) for Australia, Canada and South Africa. 
Box 8 presents a case study of policies to promote the migration of the highly-skilled in Denmark and Norway.

\section{Box 8. Policies to promote the migration of the highly-skilled: Denmark and Norway}

In general, OECD countries have moderately open policies to the immigration of highly-skilled workers. Yet, with the exceptions of Australia, Canada, Ireland, New Zealand and the United Kingdom, OECD countries have had limited success in attracting high-skilled labour force. Perhaps it is not by accident that countries that have been most successful in tapping into the global supply of highly skilled workers are those where English is the most spoken language (with the notable exception of the United States, where the level of high-skilled migration has been low relative to the size of the economy). The increased mobility and connectivity of the "creative class" (Florida, 2005) eases the global job matching process and widens the range of choices of both employers and job-seekers. Hence, opening up to migration may no longer be sufficient to attract the highly-skilled, and active recruitment measures may be necessary.

Among OECD countries, Denmark and Norway are relatively recent migration countries, where foreign-born population rates are below the OECD average. The two countries have recently introduced policies to promote the attraction of highly-skilled migrant workers, with some evidence of success.

In Denmark, in recent years there has been a clear (though small) brain drain: high-skilled Danes have been moving abroad, while the country has attracted relatively few high-skilled immigrants. However, the net emigration of highly-skilled people is rather small, as most emigrant Danes come back after some years. In addition, Denmark does not have a good track record of integrating immigrants, especially from non-western countries, into the labour market: the gap between the employment rates of native born and foreign born individuals is the largest in the OECD. Denmark has a low share of professional or technically-skilled immigrants in total compared with other OECD countries. A survey by the Danish National Institute of Social Research found that $80 \%$ of Danes declare themselves "positive" towards having immigrants as colleagues, but high-skilled immigrants often say that they do not feel very welcome in Denmark.

Lengthy and cumbersome administrative procedures for work and residence permits and high income tax rates were cited as the two areas creating the most problems for foreign knowledge workers in a 2007 Oxford Research study of attitudes of expatriates in Denmark. In addition, a lack of international schools is a recurrent obstacle for attracting more talented foreign workers to Denmark.

In order to respond to the above challenges, the Danish Labour Market Commission recommended a number of measures to attract foreign workers, including reducing the income floor in the "Pay Limit Scheme" and expanding the "Positive List". Denmark also introduced the "Green Card" scheme, a job-search visa allowing high-skilled immigrants to come to the country to search for a job. Qualification is through a points system, which considers education, language skills (both in a Scandinavian language and/or in English or German), experience, age, prior wages, and professions on the Danish Job Card Scheme shortage list. Green-card holders have six months to find a job on the Job Card Scheme shortage list (generally masters-level occupations) or a job paying at least DKK 463000 (EUR 63 000) annually. International students are also granted a green card, which enables them to stay and look for a job for six months after graduation.

As of 2010, a tax reform reduced the marginal tax rates including on the highest income earners, making it more attractive for highly-paid specialists to remain in Denmark after the three-to-five years expatriate gross wage tax (which allows certain foreign researchers and other approved staff to pay a gross tax rate of $25 \%$ for three years or $33 \%$ for five years rather than the normal income tax rates). It may also stem the outflow of talented Danes.

Recent progress was also made in regard to international schools: the Danish Parliament passed a law in early 2009 allowing three additional public schools to offer an international baccalaureate programme (seven schools already do so). In terms of active policies, Denmark has set up a "work in Denmark" centre in New Delhi, to attract highly-skilled immigrants, such as healthcare workers, engineers and IT and communications specialists.

In Norway, many have worried as to whether there are enough highly-skilled employees to satisfy current needs of the labour market. The OECD 2008 Economic Survey of Norway noted that existing immigration quota for highly-skilled people was never filled: inflow of such workers (who are not subject to country-specific limits) 
rarely exceeds one quarter of the annual quota of 5000 people, though in 2007 it was over one half.

In order to attract highly skilled workers, Norway has introduced an early employment scheme that entitles employers to recruit directly and let employees start working before their immigration application has been processed. The scheme applies to skilled workers, defined by expertise, and specialists, defined by pay. In addition, Norway has made it easier for international students to access the labour market during their studies. Recent changes in legislation allow students a general part-time (20 hours per week) work permit, and an offer of employment is no longer required.

In both countries, because English is widely spoken by residents as a second language, it can serve as a transition language in the workplace, while immigrants learn Danish and Norwegian in parallel. In 2009, immigrants could receive funded language instruction for up to 2000 hours in Denmark. Of course such schemes are more relevant for long-term workers, as the time investment required of a skilled immigrant and the opportunity cost of learning a new language to the required level are not fully compatible with a temporary work assignment.

There is evidence that the above schemes have led to some successful results. For example, the OECD 2009 Economic Survey of Denmark notes that the country has made impressive progress in recent years in terms of labour market integration of immigrants, and there has been a noteworthy impact of migration on employment growth. High-skilled immigration from outside the European Economic Area has increased by a factor of three (Denmark) and four (Norway) between 2004 and 2007. In both countries, India is the principal source country, accounting for $20 \%$ of high skilled immigrants to Norway but fully $50 \%$ of those to Denmark. In 2009, Norwegian highly-skilled migration levels stood in relative terms at about one-third of Canadian levels.

Source: This case study draws on OECD (2010f); OECD (2009d); OECD (2009e); OECD (2008g); OECD (2008h); Chaloff \& Lemaître (2009).

\section{Conclusion}

This section has provided an overview of policies that governments can implement to open the economy, shape the adjustments induced by liberalisation and ensure the gains from openness are optimised. In a G20 perspective, Japan has actively promoted the free movement of goods and capital, but more could be done to attract investment, innovation activities and highly-skilled individuals that can generate positive spillovers on the national economy. In particular:

- $\quad$ Trade policy. Japan has low average tariffs and a high degree of trade facilitation. The country has also promoted multilateral and regional trade liberalisation, as well as outward flows of goods and services. However, foreign operators still face significant non-tariff measures when exporting to Japan.

- Investment policy and investment promotion. Japan is one of the countries with the lowest number of BITs and total IIAs among G20 countries, though recently it has been engaged in several negotiations of BITs or other types of agreements containing investment provisions. In the G20 framework, Japan is among the countries with the highest level of restrictions to FDI. The number of greenfield projects in innovation related activities in Japan has been relatively low in recent years.

- Tax policy. Japan displays the highest average corporate tax rates among OECD countries that are also members of the G20.

- Policies to foster the internationalisation and openness of $R \& D$ and innovation. Recently Japan has introduced a number of policies in this area: R\&D tax incentives; a reform to foster regional activities and revitalise urban areas; and changes in its IPR legislation, as well as specific IPR support towards SMEs. However, international collaboration in industry and science is weaker 
than in many other OECD countries.

- Labour market policies. Japan's tax wedge is well below the values of large EU countries and OECD average and on par with the United States. In addition, the level of employment protection in Japan is relatively low and below the OECD average.

- Policies to encourage skilled labour migration and mobility. Japan has introduced special migration schemes for highly skilled workers. It has also introduced programmes to encourage return migration and therefore stimulate brain circulation. 


\section{REFERENCES}

Aalto University (2011, 2 February), "Endowment to support Aalto University world-class research and education". Retrieved from $w w w$.aalto.fi:

http://studies.aalto.fi/en/current/news/view/endowment_to_support_aalto_university_worldclass_research_and_education/.

Acemoglu, D. (2009), Modern Economic Growth, Princeton University Press: Princeton.

Acemoglu, D. and J. Ventura (2002), “The World Income Distribution", Quarterly Journal of Economics 117, pp. 659-694.

Aghion, P. and P. Howitt (1992), "A Model of Growth Through Creative Destruction”, Econometrica, Vol. 60, No. 2, pp. 323-351.

Aghion, P. and P. Howitt (2009), The Economics of Growth, Cambridge, MA: The MIT Press.

Alfaro, L. (2003), “Foreign Direct Investment and Growth: Does the Sector Matter?”, Harvard Business School.

Alfaro, L., A. Chanda, , S. Kalemli-Ozcan and S. Sayek (2010), "Does foreign direct investment promote growth? Exploring the role of financial markets on linkages", Journal of Development Economics 91, pp. 242-256.

Badinger, H. and F. Breuss (2004), "What Has Determined the Rapid Post-War Growth of Intra-EU Trade? Review of World Economics, Vol. 140 (1), pp. 31-51.

Barro, R. J. and J.-W. Lee (2010), "A New Data Set of Educational Attainment in the World, 1950-2010", NBER Working Paper No. 15902, Cambridge, MA: NBER.

Bartok, C. and O. Onodera (2007), "Facilitating Trade and Structural Adjustment Chile: Experiences in Non-Member Economies", OECD Trade Policy Working Papers, No. 56, Paris: OECD Publishing.

Bassanini, A. and S. Scarpetta (2001), "The driving forces of economic growth: panel data evidence for the OECD countries", OECD Economic Studies No.33, 2001/II , pp. 9-56.

Bassanini, A. and D. Venn (2007), "Assessing the Impact of Labour Market Policies on Productivity: A Difference-in-Differences Approach", OECD Social, Employment and Migration Working Papers, No. 54, Paris: OECD Publishing.

Belke, A. and L. Wang (2005), “The Degree of Openness to Intra-Regional Trade - Towards Value-Added Based Openness Measures”, Diskussionspapiere aus dem Institut für Volkswirtschaftslehre der Universität Hohenheim Nr. 257/2005, Hohenheim: Department of Economics, University of Hohenheim. 
Bernard, A. B., B. J. Jensen, S. Redding and P. K. Schott (2007), "Firms in International Trade", CEP Discussion Paper No 795, Centre for Economic Performance, London School of Economics.

Berg, A. and A. O. Krueger (2003), "Trade, Growth, and Poverty: A Selective Survey", IMF Working Paper No. 03/30, Washington DC: IMF.

Bhagwati, J. (2008), Termites in the Trading System: How Preferential Agreements Undermine Free Trade, Oxford University Press.

Boekholt, P., J. van Til, E. Arnold, T. Jansson, R. Rannala, M. Ruiz Yaniz and B. Tiefenthaler (2010), "International Cooperation of Competence Research Centres", Final Report of the COMPERA Joint Study, IWT Flanders.

Bouis, R., R. Duval, and F. Murtin (2011),"The Policy and Institutional Drivers of Economic Growth Across OECD and Non-OECD Economies: New Evidence from Growth Regressions", $O E C D$ Economics Department Working Papers, No. 84, Paris: OECD Publishing.

Braconier, H., K. Ekholm and K.H. Midelfart Knarvik (2001), "Does FDI work as a channel for R\&D spillovers? Evidence based on Swedish data", IUI Working Paper No. 553, Stockholm: IUI, The Research Institute of Industrial Economics.

Branstetter, L. (2006), "Is foreign direct investment a channel of knowledge spillovers? Evidence from Japan's FDI in the United States”, Journal of International Economics , Volume 68, Issue 2, pp. 325344 .

Brenton, P., R. Newfarmer, W. Shaw and P. Walkenhorst (2009), "Breaking into new markets: An overview", in: R. Newfarmer, W. Shaw and P. Walkenhorst, Breaking into new markets: Emerging lessons from export diversification (pp. 1-35), Washington, DC: The World Bank.

Brundenius, C., B. Göransson and J. Ågren (2008), "The Role of Academic Institutions in the National System of Innovation and the Debate in Sweden", UniDev Discussion Paper Series Paper no. 9, University of Lund.

Caves, R. (1996), Multinational Enterprise and Economic Analysis, Cambridge, England: Cambridge University Press.

CEN and CENELEC (2010), European Standardization and the EU 2020 Strategy, Brussels.

Chaloff, J. and G. Lemaitre (2009), "Managing Highly-Skilled Labour Migration: A Comparative Analysis of Migration Policies and Challenges in OECD Countries", OECD Social, Employment and Migration Working Papers, No. 79, Paris: OECD Publishing.

Chen, W. (2011), "The effect of investor origin on firm performance: Domestic and foreign direct investment in the United States", Journal of International Economics 83, pp. 219-228.

Coe, D. T. and E. Helpman (1995), “International R\&D Spillovers”, European Economic Review 39, pp. 859-887.

Cohen, W. M. and D. A. Levinthal (1990), "Absorptive Capacity: A New Perspective on Learning and Innovation”, Administrative Science Quarterly, Vol. 35, No. 1, Special Issue: Technology, Organizations, and Innovation, pp. 128-152. 
Corbo, V. (1997), “Trade Reform and Uniform Import Tariffs: The Chilean Experience”, The American Economic Review, Vol. 87, No. 2, Papers and Proceedings of the Hundred and Fourth Annual Meeting of the American Economic Association, pp. 73-77.

Corcos, G., D. M. Irac, G. Mion and T. Verdier (2010), “The determinants of intrafirm trade”, mimeo.

de Mello, L. R. (1999),"Foreign Direct Investment-led Growth: Evidence from Time Series and Panel Data", Oxford Economic Papers 51, pp. 133-151.

Deardoff, A. (2001), "Glossary of International Economics”. Retrieved from wwwpersonal.umich.edu/ alandear/glossary/.

Desai, M. A., F. C. Foley and J. R. Hines (2009), "Domestic Effects of the Foreign Activities of US Multinationals", American Economic Journal: Economic Policy 1:1, pp. 181-203.

Deutsche Welle (2003), “A Quick Guide to “Agenda 2010”, www.dwworld.de/dw/article/0,,988374,00.html.

Dollar, D. (1992), “Outward-Oriented Developing Economies Really Do Grow More Rapidly: Evidence from 95 LDCs, 1976-1985”, Economic Development and Cultural Change, Vol. 40, No. 3, pp. 523 544.

Dunning, J. H. and R. Narula (2004), Multinationals and Industrial Competitiveness: A New Agenda, Northampton, MA: Edward Elgar Publishing.

Eaton, J. and S. Kortum (1996), "Measuring technology diffusion and the international sources of growth", Eastern economic journal, vol.22, no. 4 , pp. 401-410 .

Eaton, J. and S. Kortum (2001), “Trade in Capital Goods”, European Economic Review 45, pp. 1195-1235.

Edquist, C. (2010), “The Swedish Paradox - Unexploited Opportunities!”, Paper no. 2010/05, Centre for Innovation, Research and Competence in the Learning Economy (CIRCLE), Lund University.

Edquist, C., T. Luukkonen and M. Sotarauta (2009),"Broad-Based Innovation Policy", in: The Evaluation of the Finnish National Innovation System, pp. 11-70, The Research Institute of the Finnish Economy.

Edwards, S. (1998), “Openness, Productivity and Growth: What do We Really Know?", The Economic Journal, Vol. 108, No. 447, pp. 383-398.

Engman, M. (2005), "The Economic Impact of Trade Facilitation", OECD Trade Policy Working Papers, No. 21, Paris: OECD Publishing.

European Commission (2008), “The economy of Germany: powered by reform”, European Economy News, Issue 9 January 2008.

Falzoni, A. M. andM. Grasseni (2005), "Home Country Effects of Investing Abroad: Evidence from Quantile Regressions", CESPRI Working Paper n. 170, Milan: Bocconi University.

Florida R. (2005), The Flight of the Creative Class. The New Global Competition for Talent, Harper Business, Harper Collins. 
Frankel, J. and D. Romer (1999), “Does Trade Cause Growth?”, The American Economic Review Vol. 89, No. 3 (Jun., 1999), pp. 379-399.

Frankel, J. and A. K. Rose (2002), "An Estimate of the Effect of Common Currencies on Trade and Income", The Quarterly Journal of Economics, vol. 117 (469), pp. 437-466.

Gallup (2008), “Gallup World Poll 2008”, www.gallup.com.

Globerman, S., A. Kokko and F. Sjöholm (2000), "International Technology Diffusion: Evidence from Swedish Patent Data", Kyklos, Vol. 53, pp. 17-38.

Görg, H. and D. Greenaway (2003), "Much Ado About Nothing? Do Do Domestic Firms Really Benefit from Foreign Direct Investment?”, IZA DP No. 944, Bonn: Institute for the Study of Labour (IZA).

Grossman, G. M. and E. Helpman (1991), "Quality Ladders in the Theory of Growth", The Review of Economic Studies, Vol. 58, No. 1, pp. 43-61.

Grossman, G. and E. Rossi-Hansberg (2006), "The Rise of Offshoring: It's not Wine for Cloth anymore”, Paper presented at The Federal Reserve Bank of Kansas City's Jackson Hole, Wyoming Conference for Central Bankers.

Grossman, G. and E. Rossi-Hansberg (2008), "Trading Tasks: A Simple Theory of Offshoring”, American Economic Review 98:5, pp. 1978-1997.

Guellec, D. and M. Cervantes (2001),"International Mobility of Highly Skilled Workers: From statistical analysis to policy formulation", in: OECD, International Mobility of the Highly Skilled (pp. 71-98), Paris: OECD.

Hajkova, D., G. Nicoletti, L. Vartia and K.-Y. Yoo (2006), "Taxation and business environment as drivers of foreign direct investment in OECD countries", OECD Economic Studies No. 43, 2006/2, Paris: OECD Publishing.

Harrison, A. (1996), "Openness and growth: A time-series,cross-country analysis for developing countries", Journal of Development Economics Vol. 48,pp. 419-447.

Hatzigeorgiou, A. (2010), "The contribution of migrants in enhancing foreign trade", in: OECD, Open for Business: Migrant Entrepreneurship in OECD Countries (pp. 273-270), Paris: OECD Publishing.

Hawkins, P. A. (2003), The open economy and its financial constraints, Cheltenam: Edward Elgar Publishing.

Herzer, D. (2010), “Outward FDI and economic growth", Journal of Economic Studies Vol. 37 No. 5, pp. 476-494.

HM Treasury (2005), "EU Membership and Trade", Unclassified .

HM Treasury(2007), The Single Market: A vision for the 21 st century, London.

Hu, A. G. (2004), "Multinational Corporations, Patenting, and Knowledge Flow: The Case of Singapore", Economic Development and Cultural Change, Vol. 52, No. 4, July 2004, pp. 781-800. 
Huber, P., M. Landesmann, C. Robinson, R. Stehrer, R. Hierländer, A. Iara, M. O’Mahony, K. Nowotny and F. Peng (2010), "Migration, Skills and Productivity", wiiw Research Reports 365, The Vienna Institute for International Economic Studies.

Hunt, J. (2010), "Skilled immigrants' contribution to innovation and entrepreneurship in the United States", in: OECD, Open for Business: Migrant Entrepreneurship in OECD Countries (pp. 257-272), Paris: OECD Publishing.

Ilkovitz, F., A. Dierx, V. Kovacs and N. Sousa (2007), "Steps towards a deeper economic integration: the Internal Market in the 21st century. Contribution to the Single Market Review", Economic Papers No. 271, Brussels: Directorate-General for Economic and Financial Affairs, European Commission.

IMD (2011), World Competitiveness Yearbook, Lausanne: IMD.

Javorcik, B. (2004), "The Composition of Foreign Direct Investment and Protection of Intellectual Property Rights: Evidence from Transition Economies", European Economic Review, Vol. 118, pp. $39-42$.

Johansson, A.., C. Heady, J. Arnold B. Brys and L. Varia (2008),"Taxation and Economic Growth", OECD Economics Department Working Papers, No. 620, Paris: OECD Publishing.

Kalinova, B., A. Palerm, and S. Thomsen (2010), “OECD's FDI Restrictiveness Index: 2010 Update", OECD Working Papers on International Investment, 2010/3, Paris: OECD Publishing.

Kao, J. (2009), “Tapping the World’s Innovation Hot Spots”, Harvard Business Review March 2009.

Keller, W. (2004), "International Technology Diffusion”, Journal of Economic Literature Vol. XLII, pp. $752-782$.

Kerr, S. P. and W. R. Kerr (2011), "Economic Impacts of Immigration: A Survey”, NBER Working Paper 16736, Cambridge, MA: NBER.

Kim, J. (2010), "Recent Trends in Export Restrictions", OECD Trade Policy Working Papers, No. 101, Paris: OECD Publishing.

Kiyota, K. (2006), "Reconsidering the Effects of Intranational and International R\&D Spillovers on Productivity Growth: Firm-level evidence from Japan", RIETI Discussion Paper Series 06-E-001: www.rieti.go.jp/en/publications/act_dp.html.

Kokko, A. (2006), “The home country effects of FDI in developed economies”, EJS Working Paper No. 225, Stockholm: European Institute of Japanese Studies.

Ledermann, D., M. Olarreaga and L. Payton, (2006),"Export Promotion Agencies: What Works and What Does Not", World Bank Trade Note 30, Washington, DC: The World Bank.

Lesser, C. (2007), "Do Bilateral and Regional Approaches for Reducing Technical Barriers to Trade Converge Towards the Multilateral Trading System?", OECD Trade Policy Working Papers, No. 58, Paris: OECD Publishing.

Li, X., D. Greenaway, and R. C. Hine (2003), "Import of services and economic growth: a dynamic panel approach", SETI Project - Sustainable growth, Employment creation and Technological Integration 
in the European knowledge-based economy, GEP, School of Economics, University of Notthingham.

Lloyd, P. and D. MacLaren (2002), "Measure of trade openness using CGE analysis", Journal of Policy Modeling 24(2002), pp. 67-81.

Ltt Tutkimus Oy (2007), "The implications of R\&D offshoring on the innovation capacity of EU firms". Retrieved from www.proinno-europe.eu.

Lutz, W., A. Goujon, K. Samir and W. Sanderson (2007), "Reconstruction of populations by age, sex and level of educational attainment for 120 countries for 1970-2000", in: Vienna Yearbook of Population Research 2007 (pp. 193-235).

Marin, D. (2010), “Germany's super competitiveness: A helping hand from Eastern Europe”. Retrieved from $w w w$. voxeu.eu.

Mattoo, A., R. Rathindran and A. Subramanian (2001), "Measuring Services Trade Liberalization and its Impact on Economic Growth", World Bank Policy Research Working Paper 2655, Washington, DC: The World Bank.

Mauro, P. (1995), “Corruption and Growth”, The Quarterly Journal of Economics 110 (3), pp. 681-712.

Melitz, M. J. (2003), "The impact of trade on intra-industry reallocations and aggregate industry productivity", Econometrica, vol. 71, No. 6, pp. 1695-1725.

Melitz, M. and G. Ottaviano (2008), "Market size, trade and productivity", Review of Economic Studies, 75 , pp. 295-316.

Miroudot, S., R. Lanz and A. Ragoussis (2009), "Trade in Intermediate Goods and Services", OECD Trade Policy Working Papers No. 93, Paris: OECD Publishing.

Molnar, M., N. Pain and D. Taglioni, (2008), "Globalisation and Employment in the OECD", OECD Economic Studies No. 44, 2008/1, Paris: OECD Publishing.

Nicoletti, G, S. Golub, D. Hajkova, D. Mirza and K.Y. Yoo (2003), "The Influence of Policies on Trade and Foreign Direct Investment", OECD Economic Studies, Vol. 2003/1, Paris: OECD Publishing.

Nordas, H. K., S. Miroudot and P. Kowalski (2006), "Dynamic Gains from Trade", OECD Trade Policy Working Papers No. 43, Paris: OECD Publishing.

Notaro, G. (2002), "European Integration and Productivity: Exploring the Gains of the Single Market", London Economics Working Paper.

Obashi, A., K. Hayakawa, T. Matsuura, and K. Motohashi (2010), "A Two-dimensional Analysis of Impact of Outward FDI on Performance at Home: Evidence from Japanese Manufacturing Firms", IDE Discussion Paper No.273 .

OECD (2003), The sources of economic growth in OECD countries, Paris: OECD Publishing.

OECD (2004), OECD Economic Surveys: Germany 2004, Paris: OECD Publishing. 
OECD (2005a), "The Benefits of Liberalising Product Markets and Reducing Barriers to International Trade and Investment in the OECD”, OECD Economic Department Working Papers, No. 462, Paris: OECD Publishing.

OECD (2005b), Looking Beyond Tariffs: The Role of Non-Tariff Barriers in World Trade, Paris: OECD Publishing.

OECD (2005c), "Trade policy: Promoting investment for development", OECD Trade Policy Working Paper No. 19 , Paris: OECD Publishing.

OECD (2006a), "The Linkages between Open Services Markets and Technology Transfers", OECD Trade Policy Working Papers, No. 29, Paris: OECD Publishing.

OECD (2006b), OECD Science, Technology and Industry Outlook 2006, Paris: OECD Publishing.

OECD (2006c), OECD Economic Surveys: Germany 2006, Paris: OECD Publishing.

OECD (2007a), OECD Economic Surveys: European Union 2007, Paris: OECD Publishing.

OECD, (2007b). Tax Effects on Foreign Direct Investment: Recent Evidence and Policy Analysis, OECD Tax Policy Studies No.17. Paris: OECD.

OECD (2007c), "Effective tax rates on investment", Paris: OECD.

OECD (2007d), “Competitive Regional Clusters: National Policy Approaches”, OECD Reviews of Regional Innovation, Paris: OECD Publishing.

OECD (2008a), "Economic and Other Impacts of Foreign Corporate Takeovers in OECD Countries", in: OECD, International Investment Perspectives 2007: Freedom of Investment in a Changing World (pp. 65-91), Paris: OECD Publishing.

OECD (2008b), The Internationalisation of Business R\&D: Evidence, Impacts and Implications, Paris: OECD Publishing.

OECD (2008c), Open Innovation in Global Networks, Paris: OECD Publishing.

OECD (2008d), The Global Competition for Talent: Mobility of the Highly Skilled, Paris: OECD Publishing.

OECD (2008e), OECD Economic Surveys: Japan 2008, Paris: OECD Publishing.

OECD (2008f), OECD Economic Surveys: Germany 2008, Paris: OECD Publishing.

OECD (2008g), OECD Economic Surveys: Denmark 2008, Paris: OECD Publishing.

OECD (2008h), OECD Economic Surveys: Norway 2008, Paris: OECD Publishing.

OECD (2009a), Overcoming Border Bottlenecks: The Costs and Benefits of Trade Facilitation, Paris: OECD.

OECD (2009b), OECD Economic Surveys: European Union 2009, Paris: OECD Publishing. 
OECD (2009c), OECD Economic Surveys: Japan 2009, Paris: OECD Publishing.

OECD (2009d), International Migration Outlook: SOPEMI 2010, Paris: OECD Publishing.

OECD (2009e), OECD Economic Surveys: Denmark 2009, Paris: OECD Publishing.

OECD (2010a), Economic Globalisation Indicators, Paris: OECD Publishing

OECD (2010b), Measuring Innovation: A New Perspective, Paris: OECD Publishing.

OECD (2010c), Open for Business: Migrant Entrepreneurship in OECD countries, Paris: OECD Publishing.

OECD (2010d), Economic Policy Reforms 2010: Going for Growth, Paris: OECD Publishing.

OECD (2010e), “Tax Policy Reform and Economic Growth”, OECD Tax Policy Studies, No. 20, Paris: OECD Publishing.

OECD (2010f), OECD Science, Technology and Industry Outlook 2010, Paris: OECD Publishing.

OECD (2010g), Taxing Wages 2009, Paris: OECD Publishing.

OECD (2010h), OECD Economic Surveys: Germany 2010, Paris: OECD Publishing

OECD (2010i), International Migration Outlook: SOPEMI 2010, Paris: OECD Publishing.

OECD (2011a), Attractiveness for Innovation: Location Factors for International Investment,Paris: OECD Publishing.

OECD (2011b), Fostering innovation for green growth, Paris: OECD.

OECD and UNCTAD (2010), "Fourth Report on G20 Investment Measures", available at www.oecd.org/dataoecd/20/56/46318551.pdf.

Ottaviano, G. I. and G. Peri (2005), "Rethinking the gains from immigration: theory and evidence from the U.S", NBER Working Paper 11672, Cambridge, MA: NBER.

Ottaviano, G. I. and G. Peri (2006), “The economic value of cultural diversity: evidence from US cities", Journal of Economic Geography 6 (2006), pp. 9-44.

Pain, N., I. Koske and M. Sollie (2008), "Globalisation and OECD Consumer Price Inflation”, OECD Economic Studies No. 44, 2008/1, Paris: OECD.

Peri, G. and D. Urban (2006), "Catching-up to foreign technology? Evidence on the "VeblenGerschenkron" effect of foreign investments", Regional Science and Urban Economics, Volume 36, Issue 1, pp. 72-98 .

Ramondo, N. and A. Rodriguez-Clare (2009), "Trade, Multinational Production, and the Gains from Openness", NBER Working Paper No. 15604, Cambridge, MA: NBER. 
Rodriguez, F. and D. Rodrik (2001), "Trade Policy and Economic Growth: A Skeptic's Guide to Crossnational Evidence", in B. Bernanke and K. S. Rogoff, Macroeconomic Annals 2000, Cambridge: MIT Press.

Rodrik, D. A. Subramanian and F. Trebbi (2004), "Institutions Rule: The Primacy of Institutions Over Geography and Integration in Economic Development", Journal of Economic Growth, 9, pp. 131165.

Romer, P. M (1990), “Endogenous Technological Change", The Journal of Political Economy, Vol. 98, No. 5, pp. 71-102.

Rowthorn, R. (2008), "The fiscal impact of immigration on the advanced economies", Oxford Review of Economic Policy, Volume 24, Number 3, pp. 560-580.

Sachs, J. D. and A. Warner (1995), "Economic Reform and the Process of Global Integration" Brookings Papers on Economic Activity, Vol. 1995, No. 1, 25th Anniversary Issue, pp. 1-118.

Sakurai, T (2007), "JETRO and Japan's Postwar Export Promotion System: Messages for Latin American Export Promotion Agencies", IDE Discussion Paper NO. 127.2007.10, Institute of Developing Economies.

Schneider, H. and K. F. Zimmermann (2010), “Agenda 2010: Strategies to Achieve Full Employment in Germany", IZA Policy Paper No. 15, Bonn: Institute for the Study of Labour (IZA).

Schwaag-Serger, S. (2008), "Internationalization of science, technology and innovation - implications for national innovation policies", Presentation delivered at the Conference on Drivers of International Collaboration in Research, 13 October 2008, Brussels.

Solow, R. M. (1956), "A Contribution to the Theory of Economic Growth", The Quarterly Journal of Economics, Vol. 70, No. 1, pp. 65-94.

Spilimbergo, A. L. J. Londoño and M. Székely (1999), "Income Distribution, Factor Endowments, and Trade Openness”, IADB Working Paper 356, available at: www.iadb.org/res/publications/pubfiles/pubWP-356.pdf.

Stephan, P. E. and S. G. Levin, (2001), "Exceptional contributions to US science by the foreign-born and foreign-educated", Population Research and Policy Review 20, pp. 59-79.

Stone, S. and B. Shepherd (2011), "Dynamic gains from trade: The role of intermediate inputs and equipment imports", OECD Trade Policy Working Paper No. 110, Paris: OECD Publishing.

Tekes (2010), Tekes Annual Review 2009, Helsinki: Tekes.

The Economist (2010), “Older and wiser”, in: A Special Report on Germany, The Economist 11 March 2010.

The Economist, (2011), "Tribes still matter. How global leaders tap into diaspora networks", in: A special report on global leaders, The Economist 20 January 2011.

UNCTAD (2009), World Investment Prospect Survey, Geneva: UNCTAD. 
United Nations Department of Economic and Social Affairs, Population Division (2007), World Population Prospects: The 2006 Revision.

van Pottelsberghe de la Potterie, B. and F. Lichtenberg (2001), "Does Foreign Direct Investment Transfer Technology Across Borders?”, The Review of Economics and Statistics, MIT Press, Vol. 83(3), pp. 490-497.

Ventura, J. (1997), "Growth and Interdependence”, The Quarterly Journal of Economics, Vol. 112, No. 1, pp. 57-84.

Veugelers, R. and B. Cassiman (2004), "Foreign subsidiaries as a channel of international technology diffusion: Some direct firm level evidence from Belgium", European Economic Review, Volume 48, Issue 2, pp. 455-476.

Wan, X. (2010), “A Literature Review on the Relationship between Foreign Direct Investment and Economic Growth", International Business Research, Vol. 3, No.1, pp. 52- 56.

Whitman, M. V. (1969), "Economic Openness and International Financial Flows", Journal of Money, Credit and Banking, Vol. 1, No. 4, pp. 727-749.

Whyman, P. and M. Baimbridge (2006), "Labour Market Flexibility and Foreign Direct Investment", Employment Relations Occasional Paper, London: Department of Trade and Industry.

Winters, A. L. (2004), "Trade Liberalisation and Economic Performance: An Overview", The Economic Journal, Vol. 113, n. 493, pp. F4-F21.

World Economic Forum (2010), Stimulating Economies through Fostering Talent Mobility, Geneva: World Economic Forum.

WTO (2009), Trade Policy Review: Chile 2009, Geneva: WTO.

ZEW (2009), "Effective tax levels using the Devereux/Griffith methodology", Intermediate Report 2009 Project for the EU Commission TAXUD/2008/CC/099, Mannheim and Oxford: Centre for European Economic Research (ZEW). 


\section{ANNEX 1: ECONOMIC GROWTH THEORY AND OPENNESS ${ }^{29}$}

\section{Basic models of economic growth theory}

The reference paradigm of economic growth is the neoclassical model, which was first introduced by Solow (1956). The basic equation of this model relates the output of goods to the production factors (capital and labour) through the following function:

$Y=A K^{\alpha} L^{1-\alpha}$

where $\mathrm{A}$ is a productivity parameter and $\alpha<1$ so that production involves decreasing returns to capital. In addition, capital accumulation depends on investment (equal to aggregate savings) and capital depreciation. In the Solow model economic policy has a role in stimulating economic growth by making people save more, hence increasing capital accumulation. But policy cannot affect the long-run economic growth rate, and at some point the diminishing marginal product of capital will hinder growth. In this situation, long-run economic growth can only be sustained through an increase of A, what Solow calls "technical progress". But this technical progress is exogenous to the model. Thus, the neoclassical paradigm does a good job in describing growth as the economy converges to a steady-state, but fails to explain it.

Subsequent models have sought to explain the sources of technological progress, i.e. to make the A parameter endogenous. The first of such attempt was the AK theory. In a nutshell, this paradigm dispenses with the diminishing returns to capital assumption, and therefore the growth equation becomes

$Y=A K$

with the parameter A equal a constant. Physical and human capital is lumped together with the intellectual capital that is accumulated as a consequence of technological progress. Hence, unlike in the neoclassical model, economic growth can be sustained through policies that generate savings, part of which will end up financing a higher rate of technological progress. The main shortcoming of the AK model is that it fails to make a distinction between capital accumulation and technological progress. Another problem is that capital is essentially the only factor of production.

To overcome these problems, a second wave of endogenous growth theory makes an explicit distinction between capital accumulation and technological progress, by incorporating the importance of innovation in explaining long-run growth and cross-country convergence. One such model was developed by Romer (1990) and may be referred to as "product-variety" or "expanding-variety" model, in which innovation causes productivity growth by inducing new, though not necessarily improved, varieties of products. R\&D expands the variety of inputs and machineries used in production. Productivity growth is caused by the increased specialisation of labour that works with an increasing number of intermediate inputs and by spillovers from research activity, thanks to which innovators benefits from the existing stock of innovations. ${ }^{30}$ Grossman and Helpman (1991) focus on the variety of consumer products instead of inputs. As consumers love variety, they derive greater utility when they consumer a greater variety of products. Hence, product innovation increases utility and real income (Acemoglu, 2009). 
Another model of innovation-based endogenous growth was developed by Aghion and Howitt (1992). ${ }^{31}$ This paradigm is generally known as Schumpeterian growth theory, because it focuses on product, quality-enhancing innovations, which make new machines and products replace the obsolete ones and new innovative firms displace uncompetitive incumbents. This is the phenomenon that Schumpeter calls "creative distruction", hence the name of the model. This paradigm introduces a number of interesting issues that were not present in previous growth models. For example, the competitive aspect of innovation means that there is direct price competition between producers with different vintages of quality or different costs of production. In addition, competition between incumbents and new entrants generates a potential business stealing effect: an new firm, by replacing an old one, is also stealing its business and profits (Acemoglu, 2009). This model is analytically appealing in several respects. For example, it allows to analyse how a country's growth performance varies with its proximity to the technological frontier and to what extent the country will tend to converge to that frontier. In addition, it provides a framework for identifyind and assessing the policies that can sustain growth and convergence as a country approaches the frontier.

\section{Trade liberalisation and economic growth}

The above models were developed in a closed-economy framework. But they can be expanded to introduce interactions between countries, and thus analyse the impact of trade openness on growth. Acemoglu (2009) notes that the relation between trade and growth depends on the nature of trade, and more specifically on the framework within which such relation is modelled. The following paragraphs will review briefly the implications for the economics of growth stemming from the application of some workhorse models of international trade theory.

\section{Heckscher-Ohlin models}

In a Heckscher-Ohlin framework, trade derives from differences in factor abundance, while countries have the same (or similar) technologies. The key insight emerging from this model is that with international trade, factor prices in each country (i.e., wage rate and rental rate of capital) are determined by world prices. ${ }^{32}$ This is in contrast with a closed economy, where factor prices shaping the incentives to accumulate capital are determined by the capital-labour ratio in the economy. Trade in a Heckscher-Ohlin world results in a pattern of growth similar to the neoclassical growth model, in which growth is driven by technological change in the long run, and all countries converge towards a steady-state. However, the presence of international trade leads to substantial changes in the results relative to closed-economy models. Each country can accumulate capital without running into diminishing returns (much like an AK model): because of factor price capitalisation, for every additional unit of capital, the country receives a return that is independent of its own capital growth. And yet, there is not endogenous growth at the world level, because capital accumulation by all countries drives down the price of capital-intensive goods to a level that is consistent with the steady-state.

While in the long-run the steady-state equilibrium is stable, the model can produce different dynamics in the medium- and short-run: if a country has a lower interest rate than the rest of the world, it has an incentive to save faster and thus achieve positive income per capita growth rate. Thus, international trade can temporarily prevent diminishing returns to capital from materialising. An interesting illustration of how this model may apply to a historical experience of rapid economic growth may be found in Ventura (1997). His paper suggests that East Asian countries (the so-called "tigers") experienced rapid economic growth since the 1970 s thanks to openness to trade and capital accumulation. However, this can only happen in the medium term: at some point diminshing returns will set in and the world economy will revert to steady-state equilibrium. 


\section{Ricardian models}

Acemoglu and Ventura (2002) developed a model of growth with international trade to show that AK models can also explain convergence in world growth rates. ${ }^{33}$ In Ricardian models, international trade is driven by differences in technology (productivity) and comparative advantages. Each country affects the prices of the goods it exports to the rest of the world. Hence, the country's terms of trade (i.e., the price of its exports relative to its imports) are endogenous and depend on the rate of capital accumulation. The parameter A in equation (2) will depend on the country's terms of trade. When a country accumulates capital faster than the rest of the world, it will export more goods to the world relative to foreign exports. But this increase in exports will result in worse terms of trade (because the price of exports decreases relative to imports). The fall in terms of trade will lower the country's growth rate until it converges with the growth rate of the rest of the world.

However, this does not imply that countries with different characteristics have the same level of income. Differences in technologies across countries result in differences in income levels rather than differences in permanent growth rates.

In spite of its theoretical rigour, this model does not seem to be fully consistent with empirical evidence: in particular, the prediction that economic growth will lead to worsening terms of trade does not seem to be confirmed by the data (Aghion and Howitt, 2009).

\section{Reconciling Heckscher-Ohlin and Ricardian models}

The main difference between these models is whether the prices of goods a country supplies are affected by its own production and accumulation. In the Heckscher-Ohlin model, each country can accumulate capital without incurring into diminishing returns to capital. In the Ricardian model, terms-oftrade effects reduce the rate of return of further capital accumulation.

Although it may appear that these two models cannot be reconciled, Acemoglu (2009) suggests that they may apply to different stages of development and different kinds of goods. When a country produces goods that are standardised and could be produced in any other country, it does not face terms-of-trade effects and therefore does not experience diminishing returns to capital (i.e., it grows in an Hekscher-Ohlin world). As noted above, this may correspond to the experience of the Asian tigers and their specialisation in medium-tech goods in the 1970s and 1980s. However, as the country goes richer, it starts producing more differentiated goods and the price of the goods it exports will affect world prices. Consequently, worsening terms of trade will result in diminishing returns.

\section{Aghion and Howitt's model}

Aghion and Howitt (2009) developed a synthetic framework that embodies all the effects that trade liberalisation may have on productivity growth and innovation. They show that openness to trade may have positive effect on both the level and the growth of a country's national income. However, there are exceptions. In particular, openness to trade may have a negative effect of small and backward economies.

In their model, the influence of trade openness on national income runs through the following channels:

- Selection effect (as in Melitz, 2003). As domestic firms have to access to intermediate goods sold by more efficient producers in the world market, the less efficient producers of internediate goods are forced to exit the domestic market. This will lead to an increase of the overall level of efficiency and aggregate income. 
- Scale effect. By opening up to trade, technologically advanced producers of intermediate goods can sell their products to a larger market. The smaller the market was before the opening, the larger the gain will be.

- Backwardness effect. While less technologically advanced countries appear to gain more from trade, the effect of distance from the technological frontier is in fact ambiguous. That is, as long as the distance is not too big, the impact should positive, and directly proportional to the distance. However, if the laggards are too far from the frontier, they will lose out from openness to trade. 
DSTI/DOC(2011)2

\section{NOTES}

However, growth in emerging non-OECD economies (especially China) has resulted in rising prices of many commodities, as noted in Pain, Koske and Sollie (2008).

Annex 1 reviews the main models of economic growth theory and of the impacts of trade liberalisation on growth.

At the same time, there is less conclusive evidence of the opposite, i.e. that protection has a positive effect on productivity growth or productivity levels (Nordas, Miroudot and Kowalski, 2006).

The authors also use a trade liberalisation index based on average actual tariff rates as a proxy for trade openness, instead of the traditional share of exports and imports in GDP measure found in a large part of the existing growth regression literature. The results confirm that trade liberalisation is associated with higher speed of convergence of TFP to its steady state, and to higher long-run GDP per capita levels. In addition, barriers to trade are found to have a robust negative impact on long-run TFP. This approach may allow to solve a potential endogeneity problem and isolate the effect of trade openness on growth from business cycle co-movements between GDP and trade. In addition, the traditional trade openness variable is a performancer rather than a policy indicator, unlike a trade liberalisation index based on the level of tariff rates.

Recent firm-level models of trade show that the re-allocation of resources raises across-firm as well as within-firm productivity. Melitz (2003) describes how lower trade costs can promote re-allocation of resources to more productive firms, while unproductive firms exit. In addition, Melitz and Ottaviano (2008) model how trade costs increase competitive pressure in the domestic market, and this results in lower mark-ups and lower X-inefficiencies in firms.

In its Glossary of International Economics, Alan Deardoff defines a capital good as "[a] good, such as a machine, that, once in place, becomes part of the capital stock". It includes the machinery and equipment used in the production process and it is subject to deterioration and depreciation. An intermediate good (or intermediate input) is "an input to production that has itself been produced and that, unlike capital, is used up in production". Intermediate goods include primary goods, semi-finished goods, and parts and components and they have also been found to contribute significantly to productivity growth.

Trade in capital goods is proxied by trade of the nonelectrical equipment, electrical equipment, and instrument industries.

A detailed literature review of the relationship between services trade liberalisation and growth can be found in OECD (2006a).

However, for developing countries the coefficient has a negative sign.

Empirical analyses of the impact of FDI on host country output and productivity growth have been carried out both at the macro and at the micro level. Macroeconometric analyses include panel, cross-section and time-series evaluations using real GDP per capita as dependent variable and FDI as independent variable, plus several types of controls. Micro studies generally regress labour productivity or total factor productivity of domestic firm on a number of independent variables, including some measure of productivity spillovers from multinationals. 
The positive relationship holds when country-specific factors are introduced in the model.

The effect of FDI in service sector is ambiguous.

The purpose of horizontal FDI is to establish manufacturing facilities in multiple countries, all producing essentially the same thing but for their respective domestic or nearby markets. Vertical FDI leads to the establishment of manufacturing facilities in multiple countries, each producing a different input to, or stage of, the firm's production process (Source: Deardoff's Glossary of International Economics). Horizontal FDI is often driven by "market-seeking" purposes (or "tariff-jumping", if the presence of trade barriers in the host economy represents the main rational for the firm to invest cross-border). On the other hand, vertical FDI is efficiency-seeking, and thus closely associated with imports of intermediate goods and services.

Although policy evaluations based on cost-benefit analysis or analysis of a counterfactual of specific policies are only rarely available.

The EU has a common external tariff (CET) shared by all its member states.

It includes both ad valorem (AV) and ad-valorem equivalent (AVE) tariffs. While an AV tariff is charged as a percentage of the price, an AVE tariff is not a percentage (e.g. dollars per ton) but can be estimated as a percentage of the price. Source: WTO Glossary.

Engman (2005) specifies that trade transaction costs related to customs and administrative procedures range between $1 \%$ and $15 \%$ of the transaction value, with estimates for most countries falling within the low or middle range.

The overall ranking is based on: the number of documents to export and import; the time to export and import; and the cost to export and import.

Some analysts prefer the term "preferential trade agreements (PTAs)" rather than "regional trade agreements (RTAs)", as such agreements are not always regional in the common meaning of the term (Bhagwati, 2008). However, RTAs is the terminology that is still in use in the WTO.

WTO, Regional Trade Agreements Information System (RTA-IS). Accessed on 28 February 2010.

Report by the Consultative Board to the Director-General Supachai Panitchpakdi (2005), The future of the WTO: Addressing institutional challenges in the new millennium, WTO, Geneva.

In Japan export controls (prior approval) are maintained to ensure national security and public safety and to ensure adequate domestic supplies of certain agricultural and other primary products. For certain agricultural products, including wheat bran, rice bran, oat bran, clams, mussels and eels, the Minister of Economy, Trade and Industry needs the consent of the Minister of Agriculture, Forestry and Fisheries prior to granting export approval (Kim, 2010).

Such instruments include the Code of Liberalisation of Capital Movements and the Code of Liberalisation of Current Invisible Operations, and the Declaration and Decisions on International Investment and Multinational Enterprises.

These numbers include very different types of agreements, from purely bilateral investment treaties to free trade agreements that include investment provisions that are typically found in BITs or agreements that take a commercial and include provisions on transfers of funds.

This index covers four types of measures: $i$ ) foreign equity restrictions, ii) screening and prior approval requirements, iii) rules for key personnel; and (iv) other restrictions on the operation of foreign enterprises. 
The score for each sector is obtained by adding the scores for all four types of measures. The index covers 22 sectors and the average of these scores results in a single country score.

No comparable data is available on EATR for Australia and Mexico.

Although it is possible that immigration does have significant and sizeable impacts on specific sectors or population groups. This is especially the case for native-born workers for whom immigrants are close substitutes.

Source: OECD International Migration Database. The data source used is the Ministry of Justice of Japan, Immigration Bureau. Inflows of foreign workers concern residents with restricted permission to work (excluding temporary visitors and re-entries, and including renewals of permits). Stock of foreign labour force concerns foreigners whose activity is restricted according to the Immigration Act (revised in 1990). Permanent residents, spouses or children of Japanese national, spouses or children of permanent residents and long-term residents have no restrictions imposed on the kind of activities they can engage in while in Japan and are excluded from the data.

This annex draws on Acemoglu (2009), Modern Economic Growth, and Aghion and Howitt (2009), The Economics of Growth.

This is a consequence of the intuition that ideas and technologies are nonrival, meaning that many firms and innovators can benefit from them freely in their own research activities. At the same time, technological blueprints are excludable and reward their inventors with monopoly rents.

For a complete illustration of this model, see also Aghion and Howitt (2009).

Factor price equalisation is one of the most important theorems of the Heckscher-Ohlin model. When the relative prices of goods converge, so do relative prices of factor of production. In the case of labour, the equalisation is conditional on productivity differences across countries.

One of the main critics directed at AK models was precisely that they cannot explain cross-country or cross-regional convergence: under constant returns, two countries that share the same saving rate and depreciation rate of capital will never converge, because the two countries will always grow at the same rate independently of their amounts of accumulated capital. But this is obviously counterfactual when looking at the experience of China and the other Asian tigers (Aghion and Howitt, 2009). 